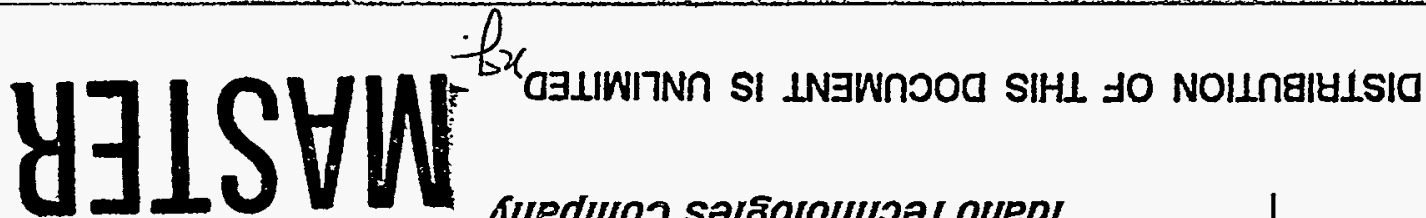 \\ గuedwos solsolouyग्। oyepI рә2чY007ћ
}

6u!sso7 $\forall \cdot d$

(әребәлб6

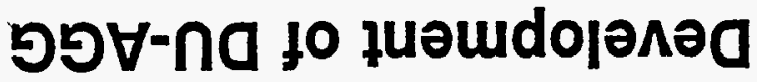

S66 taquridas

1190

982. 2640

09A느의?

SLE0/S6-7ヨNI

Asopesoge7 6u!sәəu!bug ןeuo!zeN oyepI

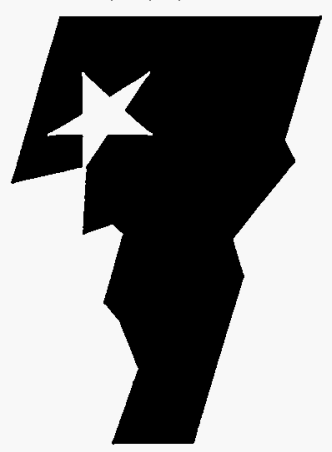




\title{
DISCLAIMER
}

This report was prepared as an account of work sponsored by an agency of the United States Government. Neither the United States Government nor any agency thereof, nor any of their employees, makes any warranty, express or implied, or assumes any legal liability or responsibility for the accuracy, completeness, or usefulness of any information, apparatus, product, or process disclosed, or represents that its use would not infringe privately owned rights. Reference herein to any specific commercial product; process, or service by trade name, trademark, manufacturer, or otherwise does not necessarily constitute or imply its endorsement, recommendation, or favoring by the United States Government or any agency thereof. The views and opinions of authors expressed herein do not necessarily state or reflect those of the United States Government or any agency thereof.

\section{Development of DU-AGG (Depleted Uranium Aggregate)}

\author{
P. A. Lessing
}

Published September 1995

\section{Idaho National Engineering Laboratory Lockheed Martin Idaho Technologies Idaho Falls, Idaho 83415}

\author{
Prepared for the \\ U.S. Department of Energy \\ Assistant Secretary for Environmental Management \\ Under DOE Idaho Operations Office \\ Contract DE-AC07-941D13223
}

INEL-95/0315 
-..

$\therefore \because$ 


\section{ABSTRACT}

This report details an experimental program to develop a low-cost, artificial mineral containing an extremely high fraction of depleted uranium oxide. The resultant material has been dubbed "DU-AGG" (depleted uranium aggregate) and is expected to be valuable as a waste disposal form or as aggregate in heavy concrete for shielding of spent nuclear fuel.

Appendices describe (a) the processes to convert gaseous depleted $\mathrm{UF}_{6}$ to different phases of uranium oxide powders, (b) sintering of fine surrogate $\mathrm{CeO}_{2}$ powder using iron-enriched basalt, and (c) the effect of high-temperature oxidation on sintered $\mathrm{UO}_{2}$ and $\mathrm{U}_{3} \mathrm{O}_{8}$. pellets. 
... 


\section{EXECUTIVE SUMMARY}

Depleted uranium oxide $\left(\mathrm{UO}_{2}\right.$ or $\left.\mathrm{UO}_{3}\right)$ powder was mixed with fine mineral additives, pressed, and heated to about $1,250^{\circ} \mathrm{C}$. The additives were chemically constituted to result in an iron-enriched basalt (IEB). Melting and wetting of the IEB phase caused the urania powder compact to densify (sinter) via a liquid phase sintering mechanism. An inorganic lubricant was found to aid in green-forming of the body. Sintering was successful in oxidizing (air), inert (argon), or reducing (dry hydrogen containing) atmospheres.

The use of ground $\mathrm{UO}_{3}$ powders ( $93 \mathrm{vol} \%$ ) followed by sintering in a dry hydrogen-containing atmosphere significantly increased the density of samples (bulk density of $8.40 \mathrm{~g} / \mathrm{cm}^{3}$ and apparent density of $9.48 \mathrm{~g} / \mathrm{cm}^{3}$, open porosity of $11.43 \%$ ). An improvement in the microstructure (reduction in open porosity) was achieved when the vol\% of $\mathrm{UO}_{3}$ was decreased to $80 \%$. The bulk density increased to $8.59 \mathrm{~g} / \mathrm{cm}^{3}$, the apparent density decreased slightly to $8.82 \mathrm{~g} / \mathrm{cm}^{3}$ (due to increase of low density IEB content), while the open porosity decreased to an excellent number of $2.78 \%$. A representative sample derived from $80 \mathrm{vol} \% \mathrm{UO}_{3}$ showed that most pores were closed pores and that, overall, the sample achieved the excellent relative density value of $94.1 \%$ of the estimated theoretical density (composite of $\mathrm{UO}_{2}$ and IEB).

It is expected that ground powders of $\mathrm{UO}_{3}$ could be successfully used to mass produce lowcost aggregate using the green-forming technique of briquetting. 



\section{CONTENTS}

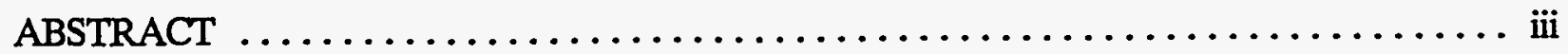

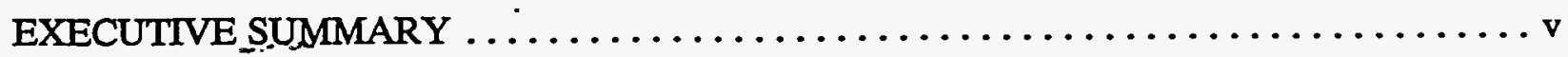

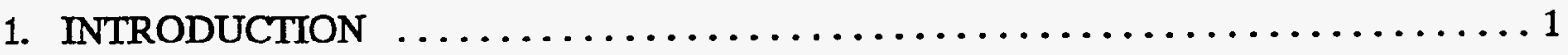

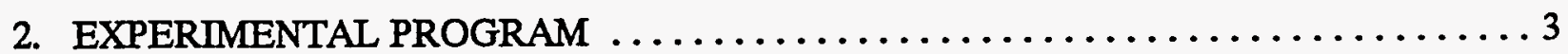

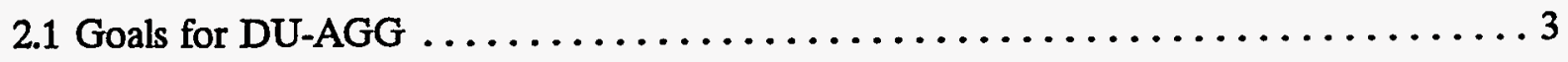

2.2 Liquid Phase Sintering Using Iron-Enriched Basalt $\ldots \ldots \ldots \ldots \ldots \ldots \ldots \ldots \ldots$

2.3 Sintering Urania with Iron-Enriched Basalt $\ldots \ldots \ldots \ldots \ldots \ldots \ldots \ldots \ldots \ldots$



3.1 Stirred Mixtures of $\mathrm{UO}_{2}$ and Iron-Enriched Basalt $\ldots \ldots \ldots \ldots \ldots \ldots \ldots \ldots \ldots \ldots \ldots \ldots \ldots$

3.2 Sintering Pressed Bodies of $\mathrm{UO}_{2}$ Powder and Ground IEB $\ldots \ldots \ldots \ldots \ldots \ldots$

3.3 Sintering Pressed Bodies of $\mathrm{UO}_{2}$ and Mixed Minerals to Yield IEB $\ldots \ldots \ldots \ldots \ldots$

3.4 Improved Sintering of $\mathrm{UO}_{2}$ and $\mathrm{UO}_{3}$ (including use of hydrogen atmosphere) $\ldots \ldots 10$

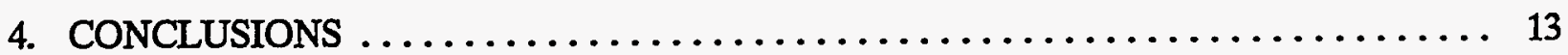

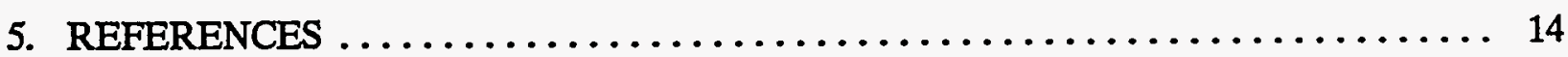

Appendix A-Production of Uranium Oxide Powders from $\mathrm{UF}_{6} \ldots \ldots \ldots \ldots \ldots \ldots \ldots$ A-1

Appendix B-High-Temperature Stability of "DUCRETE" with $\mathrm{UO}_{2}$ and $\mathrm{UO}_{3}$ Large

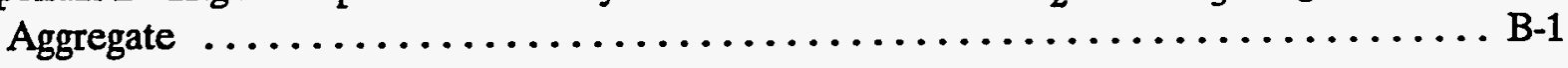

Appendix C-Liquid Phase Sintering of $\mathrm{CeO}_{2}$ Surrogate Using Iron Enriched Basalt (IEB) . C C-1

\section{FIGURES}

1. Briquettes of $\mathrm{Ce}_{2}$ sintered using Iron Enriched Basalt additive to from liquid phase ... 15

2a. Micrograph (parallel to pressing direction) of sintered $\mathrm{UO}_{3}$ sample $4-4(100 \mathrm{X}$ mag) $\ldots \ldots 15$

2b. Micrograph (parallel to pressing direction) of sintered $\mathrm{UO}_{3}$ sample $4-4(250 \mathrm{X}$ mag $) \ldots \ldots 16$

2c. Micrograph (perpendicular to pressing direction) of sintered $\mathrm{UO}_{3}$ sample $4-4(250 \mathrm{X}$ mag) 16 
3a. Micrograph (parallel to pressing direction) of sintered $\mathrm{Ce}_{2}$ sample $2 \mathrm{~A}(400 \mathrm{X}$ mag) $\ldots \ldots 17$

3b. Micrograph (perpendicular to pressing direction) of sintered $\mathrm{Ce}_{2}$ sample ( $400 \mathrm{X} \mathrm{mag)} \ldots 17$

4a. Low magnification (10X) of sample $4-2$ (cross-section, $6.27 \mathrm{~g} / \mathrm{cm}^{3}$ ); note large areas of inhomogeneous density $\ldots \ldots \ldots \ldots \ldots \ldots \ldots \ldots \ldots \ldots \ldots \ldots \ldots \ldots$

4b. Low magnification $\left(10 \mathrm{X}\right.$ ) of sample $4-2$ (parallel to pressing direction, $6.27 \mathrm{~g} / \mathrm{cm}_{3}$ ) .... 18

5a. Low magnification (10X) of sample $6-2$ (cross-section, $6.40 \mathrm{~g} / \mathrm{cm}^{3}, 90$ vol\% $\mathrm{U0}_{3}$ ) $\ldots \ldots 19$

5b. Low magnification (10X) of sample $6-2$ (parallel to pressing direction, $6.40 \mathrm{~g} / \mathrm{cm}^{3}, 90$ vol\%

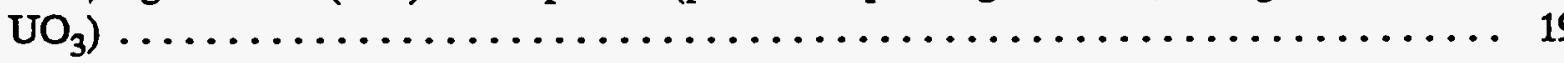

6a. Micrograph (parallel to pressing direction) of ground $\mathrm{UO}_{3}$ sintered in dry hydrogen

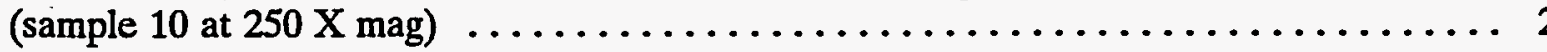

6b. Micrograph (parallel to pressing direction) of ground $\mathrm{UO}_{3}$ sintered in dry hydrogen (sample 10 at $400 \times$ mag)

\section{TABLES}

1. Average analysis of 224 North American basalts $\ldots \ldots \ldots \ldots \ldots \ldots \ldots \ldots \ldots \ldots$

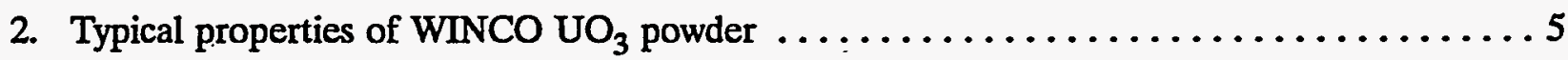

3. Experimental mixing ratio of $\mathrm{UO}_{2}$ to basalt $\ldots \ldots \ldots \ldots \ldots \ldots \ldots \ldots \ldots \ldots \ldots \ldots \ldots \ldots \ldots$

4. Sintered bulk densities of high $\mathrm{UO}_{2}$ /basalt mixtures $\ldots \ldots \ldots \ldots \ldots \ldots \ldots \ldots \ldots$

5. Sintering conditions and densities of $97 \mathrm{wt} \% \mathrm{UO}_{2}$ powder $+3 \mathrm{wt} \%$ basalt $\ldots \ldots \ldots \ldots$

6. Batch formula for basalt $\# 1 \ldots \ldots \ldots \ldots \ldots \ldots \ldots \ldots \ldots \ldots \ldots \ldots \ldots \ldots$

7. Batch formula for basalt $\# 2 \ldots \ldots \ldots \ldots \ldots \ldots \ldots \ldots \ldots \ldots \ldots \ldots \ldots \ldots$

8. Batch formula for basalt $\# 3 \ldots \ldots \ldots \ldots \ldots \ldots \ldots \ldots \ldots \ldots \ldots \ldots \ldots$

9. Batch formula for $\# 3$ basalt using component $\mathrm{A}+$ inorganic lubricant $\ldots \ldots \ldots \ldots \ldots$

10. Sintering results of $\mathrm{UO}_{3}$ plus IEB made in situ from minerals $\ldots \ldots \ldots \ldots \ldots \ldots$

11. Sintering results of $\mathrm{UO}_{3}$ varying temperature and atmosphere $\ldots \ldots \ldots \ldots \ldots \ldots$

12. $\mathrm{X}$-ray diffraction phase analysis of sintered samples $\ldots \ldots \ldots \ldots \ldots \ldots \ldots \ldots \ldots$

13. Sintering of ground $\mathrm{UO}_{3}$ powder $+\mathrm{IEB} \ldots \ldots \ldots \ldots \ldots \ldots \ldots \ldots \ldots \ldots \ldots$ 


\section{Development of DU-AGG (Depleted Uranium Aggregate)}

\section{INTRODUCTION}

The Department of Energy's (DOE's) Office of Environmental Restoration and Waste Management has chartered a study of alternative management strategies for the depleted uranium (DU) stored throughout the DOE complex. The DOE currently has a DU inventory of about 555,000 metric tons of uranium hexafluoride (375,000 metric tons of uranium content), mostly stored in 10- and 14-ton cylinders at the DOE gaseous diffusion plants. An additional 20,000 metric tons of uranium exist in the form of uranium oxides, primarily at Savannah River, and 8,000 metric tons as uranium metal. DOE is sponsoring work to evaluate disposal options and possible beneficial uses of the depleted uranium.

The Idaho National Engineering Laboratory (INEL) is developing new methods to produce high-density aggregate (artificial rock) primarily consisting of depleted uranium oxide. The objective is to develop a low-cost method whereby uranium oxide powder $\left(\mathrm{UO}_{2}, \mathrm{U}_{3} \mathrm{O}_{8}\right.$, or $\left.\mathrm{UO}_{3}\right)$ can be processed to produce high-density aggregate pieces having physical properties suitable for disposal in low-level radioactive disposal facilities or for use as a component of high-density . concrete used as radioactive shielding.

The method being developed is to utilize finely divided powder consisting of one phase of uranium oxide (or a mixture of phases of uranium oxides) and increase its packed density via pressing followed by heating (liquid phase sintering technique). The uranium oxide phases that can be used are $\mathrm{UO}_{2}, \mathrm{U}_{3} \mathrm{O}_{8}$, and $\mathrm{UO}_{3}$. Primarily, we are interested in the use of uranium oxide powders that have been depleted in ${ }^{235} \mathrm{U}$. Generally, these uranium oxides were derived from depleted $\mathrm{UF}_{6}$ or from uranium metal that was dissolved in acids, precipitated as a hydroxide, and then calcined to the oxide. An overview of various $U_{6} \rightarrow \mathrm{U}_{x} \mathrm{O}_{y}$ conversion processes is given in Appendix A of this report.

Historically, fine particle size (sinterable) $\mathrm{UO}_{2}$ powder has been pressed or extruded into a "green" body and then sintered at very high temperatures $\left(\approx 1,600\right.$ to $\left.2,000^{\circ} \mathrm{C}\right)$ in a reducing (hydrogen) atmosphere furnace in order to produce dense pellets of $\mathrm{UO}_{2}{ }^{1,2}$ The use of submicron powder particle sizes and additives have been necessary to achieve sintered densities greater than $90 \%$ of theoretical. These high-quality pellets are expensive to produce when fabricated with enriched uranium oxide for use in nuclear reactors. The $\mathrm{U}_{3} \mathrm{O}_{8}$ phase, which has a lower theoretical density, has been sintered at lower temperatures $\left(\approx 1,250^{\circ} \mathrm{C}\right)$ in air. ${ }^{3}$

We previously demonstrated that dense depleted-uranium oxide pellets (produced by traditional methods) could be used as large aggregate to replace conventional gravel. ${ }^{4}$ The resulting concrete was named "DUCRETE." This DUCRETE was shown to have compression strength levels equivalent to typical construction-grade concrete at room temperature $(3,000$ to $5,000 \mathrm{psi}$ ). Visual examinations found no deleterious interactions between the $\mathrm{UO}_{2}$ pellet aggregate and the cement/sand/water matrix when cured for 7 days at room temperature. Analysis 
of limited strength data, using two samples per data point, showed the possibility of a slight degradation in compressive strength for temperatures between $90^{\circ} \mathrm{C}$ and $150^{\circ} \mathrm{C}$ for times up to 28 days. The mean tensile strengths increased by exposure to temperatures up to $150^{\circ} \mathrm{C}$.

Reference concrete fabricated with gravel aggregate showed about a 1,300 psi decrease in mean compressive strength with exposure to temperatures of $250^{\circ} \mathrm{C}$; equivalent samples fabricated using depleted uranium oxide aggregate either cracked $\left(\mathrm{U}_{3} \mathrm{O}_{8}\right)$ or completely disintegrated $\left(\mathrm{UO}_{2}\right)$ when exposed to $250^{\circ} \mathrm{C}$ in moist air. This temperature is at least $100^{\circ} \mathrm{C}$ higher than the maximum temperature expected for anticipated applications of DUCRETE as spent nuclear fuel storage or shipping containers. However, these results bring up the possibility of degradation in strength over very long periods of time (years) at temperatures between $-25^{\circ} \mathrm{C}$ and $150^{\circ} \mathrm{C}$.

Appendix B gives results of a study intended to more clearly define the high-temperature strength degradation of DUCRETE. The high-temperature exposure study was considered to be an "oxidation" test because of the easy access of air and water vapor to the aggregate through the open pores of the cement. There was water vapor available from water not reacted to form calcium silicate hydrate compounds and also from water vapor in the atmosphere. However, the exact mechanism(s) causing the cracking and spalling of the concrete need more definition. Cracking could be caused by oxidation (volume increase) at the surface of the uranium oxide aggregate or some type of chemical reaction with the constituents of the portland cement.

Scanning electron microscope analysis evidence presented in Appendix B leads to the conclusion that there is little reaction of $\mathrm{UO}_{2}$ or $\mathrm{U}_{3} \mathrm{O}_{8}$ aggregate with the chemical compounds (e.g., $\mathrm{Ca}(\mathrm{OH})_{2}$ ) found in portland cement. However, reaction products might have been located within the cement side of the uranium oxide/cement interface and would have been difficult to find. Also, small concentrations of calcium compounds may have been present in the surface layer of uranium oxide that was cracking and therefore could have been lost during the process of preparation for analysis. There was significant evidence for diffusion of oxygen into the uranium oxide aggregate. This evidence was found both for $\mathrm{UO}_{2}$ and $\mathrm{U}_{3} \mathrm{O}_{8}$. The oxygen appears to diffuse into the aggregate because the $O / U$ values were higher at the surfaces (edge in crosssection) and in smaller grains. Since one "bare" piece of $\mathrm{U}_{3} \mathrm{O}_{8}$ disintegrated after exposure to $250^{\circ} \mathrm{C}$, this is evidence of physical/chemical changes within the urania piece large enough to exert stresses on the cement phase sufficient to cause fracture of the concrete body. 


\section{EXPERIMENTAL PROGRAM}

\subsection{Goals for DU-AGG}

This report covers an investigation to produce chunks of a synthetic, inorganic mineral that contains a very high fraction of depleted uranium. This synthetic DU-AGG should exhibit several important properties and would serve multiple purposes:

1. The uranium oxide powder needs to be compressed and densified and thus take up less volume. This is important to save costs if the material is to be stored or placed in a disposal facility. The improved density also allows for thinner walls when the urania is used in concrete as shielding for radioactive material.

2. The densified (sintered) urania-containing compound should be much more resistant to leaching (e.g., by water if disposed in the ground) than either pure urania powder or pure urania sintered via solid-state sintering. This chemical stability requirement points toward metal oxide type "ceramic" compounds. Potential reacting substances might include water, steam, oxygen, chemical phases in portland cement (e.g., $\mathrm{Ca}(\mathrm{OH})_{2}$ ), weak acids or bases, etc. Improvement in the chemical durability of the uranium oxide(s) would allow it to be used as an aggregate at high service temperatures $\left(150\right.$ to $\left.250^{\circ} \mathrm{C}\right)$, especially in portland cement.

3. The densified (sintered) material should be hard and strong. An excellent use for the sintered material is for aggregate in portland cement to form concrete. This concrete can be used as a disposal form or for heavy concrete for use in shielding of nuclear materials (e.g., spent nuclear fuel). The hardness and strength are important attributes exhibited by ordinary rock aggregate (calcite, quartzite, etc.) normally used in concrete. Strong aggregate translates into a concrete that is also strong in compression.

4. The compression/sintering process should be inexpensive when compared to existing technologies for sintering $\mathrm{UO}_{2}$. Cost reductions should be realized in the following areas: (a) reduction in amount and cost of organic binders used in "green" forming of the aggregate, (b) through the use of a high-rate (low-cost) green-forming method, and (c) a reduction in the sintering temperature (energy savings) and associated equipment cost (furnace and associated equipment).

\subsection{Liquid Phase Sintering Using Iron-Enriched Basalt}

Appendix $\mathrm{C}$ describes preliminary liquid phase sintering of $\mathrm{CeO}_{2}$ powder using iron-enriched basalt (IEB) as the liquid forming phase. Basalt is an extremely stable, erosion-resistant, natural oxide mineral produced by volcanoes. It can contain amorphous (glassy) or crystalline phases. Basalt can accommodate a variety of metal oxide additives such that basalt has a wide range of chemical compositions. Additions of iron oxide to levels higher than normally found in natural basalt (IEB) and other oxides (e.g., zirconium oxide) can aid in the formation of crystalline phases. Ceria $\left(\mathrm{CeO}_{2}\right)$ was selected as a surrogate for $\mathrm{UO}_{2}$ in order to quickly gain experimental data on optimum sintering conditions and also to measure some resultant mechanical properties 
of the sintered pieces. We successfully achieved $93 \%$ of theoretical density with IEB and $\mathrm{CeO}_{2}$ using low sintering temperatures $\left(1,250\right.$ to $\left.1,300^{\circ} \mathrm{C}\right)$. Good hardness values were obtained, and using these data, we predict that the hardness value for IEB-sintered uranium oxide should have a diamond pyramid hardness number of about 800 . Since the fracture toughness values appeared to be dependent upon the grain boundary (IEB glass/ceramic) phase, we predict that IEB-sintered uranium oxide should have a fracture toughness value of about $1.0 \mathrm{MPa} \mathrm{m}{ }^{1 / 2}$.

In traditional solid-state sintering processing of uranium oxide nuclear fuel, expensive organic binders have been added to very fine uranium oxide powder to provide sufficient plasticity for green-forming (dry pressing, extrusion, etc.) and to increase the green-density and provide sufficient strength for handling the body during green-forming and handling prior to firing. The blended powder normally has been processed through a roll compactor and then screened (or spray dried) to produce a free-flowing, granular powder. This powder was then fed into uniaxial or biaxial presses. For high production rates of pellets requiring close dimensional tolerances, a high-speed rotary press with a rotating round die table with multiple stations of punches and dies usually has been employed. 5 These rotary presses can generate 72 to 6,000 high-quality tablets per minute, each being $5 / 8$ to $2-1 / 2$ in. in diameter. Of the commercially available compression methods, roll compaction (briquetting) is the lowest-cost method to produce large quantities of compacted materials. However, briquetting produces a product less uniform in density and shape than produced from molding or tableting presses. 5

Figure 1 shows a photograph of surrogate $\mathrm{CeO}_{2}$ plus IEB that we compacted in a briquetting press and sintered into artificial "rock aggregate." Very low cost binders and water were added in order to achieve sufficient plasticity and lubrication to successfully compact the "green" pellets in the briquetting machine.

Since $\mathrm{CeO}_{2}$ surrogate can be green-compacted using the briquetting process and sintered to high densities, it is logical to expect that uranium oxide and IEB can also be compacted using the briquetting process and sintered to high densities. Our previous exploratory experiments have shown that $\mathrm{UO}_{2}$ powder can be sintered using IEB, but the process needed to be optimized. At ambient temperature, the uranium oxide contained in the liquid phase sintered aggregate is expected to be in one or more of three physical forms: (a) chemically bound in an amorphous (glass) phase, (b) chemically bound in crystalline mineral phases (uranophane, zirconolyte, coffinite, etc.), or (c) present as one of the oxide phases, but physically surrounded by the crystalline and amorphous phases. The combination of phases found in (a), (b), and (c) should isolate the uranium oxide from any liquids or gases that could react with the uranium oxide phase.

\subsection{Sintering Urania with Iron-Enriched Basalt}

Initial experiments were conducted by mixing precursor chemicals in given ratios, melting the mixture, and cooling and grinding the result into a fine powder. The average analysis of North American basalts is given in Table 1. Our synthetic basalts are enriched in iron oxides at the expense of the alumina and silica content. Subsequent sintering experiments adjusted experimental parameters, including (a) pressing pressure, (b) sintering schedule (temperature versus time), (c) sintering atmosphere (inert, oxidizing, reducing), (d) grinding and mixing techniques, (e) Starting ratio of IEB to uranium oxide (weight or volume percent), and (f) binder content. A reducing sintering atmosphere resulting from using 4 vol\% hydrogen gas in dry argon. 
Table 1. Average analysis of 224 North American basalts.

\begin{tabular}{ccccccccccc}
\hline Melt & $\mathrm{SiO}_{2}$ & $\mathrm{Al}_{2} \mathrm{O}_{3}$ & $\mathrm{FeO}$ & $\mathrm{Fe}_{2} \mathrm{O}_{3}$ & $\mathrm{CaO}$ & $\mathrm{MgO}$ & $\mathrm{Na}_{2} \mathrm{O}$ & $\mathrm{K}_{2} \mathrm{O}$ & $\mathrm{TiO}_{2}$ & $\mathrm{ZrO}_{2}$ \\
\hline Avg. & 49.9 & 16.0 & 8.4 & 2.7 & 9.7 & 6.5 & 2.7 & 0.8 & 1.6 & 1.5 \\
\hline \multicolumn{7}{c}{}
\end{tabular}

Gases listed as "wet" were humidified by bubbling the gas through distilled water held at room temperature.

Urania powders were from several sources. $\mathrm{UO}_{2}$ was made from the direct oxidation of uranium metal by Babcock \& Wilcox at the Special Manufacturing Company facility at the INEL. The powder was used as-formed (agglomerated) with the only grinding occurring during the mixing processes. The the $\mathrm{UO}_{3}$ used was from the fluidized bed calcination of uranium nitrate by the Westinghouse Idaho Nuclear Company (WINCO) at their Chemical Processing Plant facility at the INEL. This powder was not ground after calcination (denitration), and typically has the properties detailed in Table 2.

Table 2. Typical properties of $\mathrm{WINCO} \mathrm{UO}_{3}$ powder.

\begin{tabular}{|c|c|c|c|c|c|c|}
\hline & & \multicolumn{3}{|c|}{ Particle size distribution } & & \\
\hline \multicolumn{2}{|c|}{$\begin{array}{c}\text { Densities } \\
\left(\mathrm{g} / \mathrm{cm}^{3}\right)\end{array}$} & \multicolumn{2}{|c|}{ Tyler mesh } & \multirow{2}{*}{$\frac{\mathrm{Wt} \%}{15}$} & \multicolumn{2}{|c|}{$\begin{array}{c}\text { Composition } \\
\text { (wt\%) }\end{array}$} \\
\hline Bulk & 4.10 & +40 & & & $\mathrm{UO}_{3}$ & 99.29 \\
\hline Tapped & 4.30 & -40 & +60 & 13 & $\mathrm{U}_{3} \mathrm{O}_{8}$ & 0.06 \\
\hline Fluidized & 3.00 & -60 & +100 & 25 & Nitrate & 0.50 \\
\hline \multirow[t]{4}{*}{ Crystal } & 7.29 & -100 & +200 & 37 & $\mathrm{H}_{2} \mathrm{O}$ & 0.15 \\
\hline & & -200 & +325 & 7 & & 100.00 \\
\hline & & -325 & & 3 & & \\
\hline & & & Total & 100 & & \\
\hline
\end{tabular}




\section{RESULTS AND DISCUSSION}

\subsection{Stirred Mixtures of $\mathrm{UO}_{2}$ and Iron-Enriched Basalt}

We performed-sintering experiments in which a synthetic basalt was mixed (just stirred together-no pressure used) with powdered $\mathrm{UO}_{2}$ in the following ratios, as shown in Table 3.

When using 50-90 wt\% $\mathrm{UO}_{2}$ powder and synthetic basalt, the melt wetted the powder and slumped (like a viscous liquid), as a result of heating to $1,450-1,500^{\circ} \mathrm{C}$, and when cooled to low temperature resulted in a solid body. However, the body retained the shape of the crucible in which it was contained and stuck to the crucible wall. Therefore, these bodies did not shrink in accordance with known liquid phase sintering mechanisms. When $90-97 \mathrm{wt} \% \mathrm{UO}_{2}$ powder was used, the body retained its shape at high temperature and sintered (shrinked/densified). After these initial experiments, the wt\% $\mathrm{UO}_{2}$ powder was kept in the 90-97 wt\% range (3-10 wt\% synthetic basalt) in order to refine the liquid phase sintering process.

\subsection{Sintering Pressed Bodies of $\mathrm{UO}_{2}$ Powder and Ground IEB}

Subsequently, $\mathrm{UO}_{2}$ powder and ground synthetic basalt powder were pressed into pellets and sintered to $1,450-1,500^{\circ} \mathrm{C}$ in air. Bulk densities were measured as shown below in Table 4 .

$\mathrm{X}$-ray diffraction analysis (after sintering) of the $97 \mathrm{wt} \% \mathrm{UO}_{2}$ sample showed the phase composition to be $83 \% \mathrm{U}_{3} \mathrm{O}_{8}, 7.5 \% \mathrm{UO}_{3}, 6.6 \% \mathrm{UO}_{2} \mathrm{Cl}$ (possibly), $2.9 \% \mathrm{USiO}_{4}$.

Next, a series of experiments were conducted to try to improve the sintered density of the DU-AGG using $97 \mathrm{wt} \% \mathrm{UO}_{2}$ powder and synthetic basalt. Results from these experiments are shown in Table 5.

Table 3. Experimental mixing ratio of $\mathrm{UO}_{2}$ to basalt.

\begin{tabular}{cc}
\hline Weight percent $\mathrm{UO}_{2}$ powder & Weight percent basalt \\
\hline 50 & 50 \\
75 & 25 \\
85 & 15 \\
90 & 10 \\
95 & 5 \\
97 & 3 \\
\hline
\end{tabular}


Table 4. Sintered bulk densities of high $\mathrm{UO}_{2}$ /basalt mixtures.

\begin{tabular}{ccc}
\hline & Mixture & $\begin{array}{c}\text { Measured bulk density } \\
\left(\mathrm{g} / \mathrm{cm}^{3}\right)\end{array}$ \\
\hline 1 & $95 \mathrm{wt} \% \mathrm{UO}_{2}$ & 6.47 \\
2 & $95 \mathrm{wt} \% \mathrm{UO}_{2}$ & 6.53 \\
3 & $97 \mathrm{wt} \% \mathrm{UO}_{2}$ & 6.48 \\
4 & $97 \mathrm{wt} \% \mathrm{UO}_{2}$ & 6.78 \\
\hline
\end{tabular}

Table 5. Sintering conditions and densities of $97 \mathrm{wt} \% \mathrm{UO}_{2}$ powder $+3 \mathrm{wt} \%$ basalt.

\begin{tabular}{clccccc}
\hline Sample \# & Atmosphere & $\begin{array}{c}\text { Sintering } \\
\text { temperature } \\
\left({ }^{\circ} \mathrm{C}\right)\end{array}$ & $\begin{array}{c}\text { Pressing } \\
\text { pressure } \\
(\mathrm{psi})\end{array}$ & $\begin{array}{c}\text { Bulk } \\
\text { density } \\
\left(\mathrm{g} / \mathrm{cm}^{3}\right)\end{array}$ & $\begin{array}{c}\text { Apparent } \\
\text { density } \\
\left(\mathrm{g} / \mathrm{cm}^{3}\right)\end{array}$ & $\begin{array}{c}\text { Open } \\
\text { porosity } \\
(\%)\end{array}$ \\
\hline 1 & Air & 1,500 & 11,800 & 5.28 & 5.57 & 5.14 \\
2 & Air & 1,500 & $24,945^{\mathrm{a}}$ & 5.70 & 6.50 & 12.27 \\
3 & Argon & 1,350 & 13,304 & 5.61 & 5.97 & 6.02 \\
4 & Argon & 1,350 & 13,304 & 5.90 & 6.29 & 5.65 \\
5 & Argon & $1,250^{\mathrm{b}}$ & 13,304 & 6.88 & 7.10 & 3.21 \\
6 & Argon & 1,250 & 13,304 & $\mathrm{NA}$ & $\mathrm{NA}$ & $\mathrm{NA}$ \\
7 & Argon & 1,275 & 13,304 & 6.08 & 6.43 & 5.40 \\
8 & Argon & 1,275 & 13,304 & 5.91 & 6.13 & 5.40 \\
9 & Argon & 1,200 & 13,304 & 6.75 & 7.25 & 6.87
\end{tabular}

a. Contained $\mathbf{0 . 2 5 \%}$ organic binder.

b. One hour hold at $1,100^{\circ} \mathrm{C}$.

The bulk density is calculated on the total volume of the sample and thus includes both pores or cracks open to the surface and closed or isolated pores. The apparent density value includes the closed pores only and has a value the same or higher than the bulk density. The theoretical or crystal densities do not include any pores.

From these results, we concluded that liquid phase sintering occurs in the temperature range of about $1,200-1,500^{\circ} \mathrm{C}$ in a sintering atmosphere that can be oxidizing (air) or inert (argon). If the temperature gets much over $1,450^{\circ} \mathrm{C}$, there is a tendency for bubbling or frothing as some of the components lose oxygen. This is especially true for $\mathrm{Fe}_{2} \mathrm{O}_{3}$ as it converts into $\mathrm{Fe}_{3} \mathrm{O}_{4}$. 


\subsection{Sintering Pressed Bodies of $\mathrm{UO}_{2}$ and Mixed Minerals to Yield IEB}

We then conducted experiments to form artificial basalt in situ during the sintering process (rather than melt and homogenize the basalt, cool and grind the basalt). The idea was to simplify the total process and reduce energy costs. Finely ground chemical components were mixed together and then added to the starting urania.powder. Typical batch formulations (basalt fraction only) utilizing these components are given below in Tables 6, 7, and 8. Component $A$ is a complex mixture of calcined and ground metal oxides. Components $\mathrm{B}$ and $\mathrm{C}$ are metal oxides that aid in the wetting of the liquid phase to the urania powder.

Table 6. Batch formula for basalt \#1.

\begin{tabular}{lcc}
\hline \multicolumn{1}{c}{ Chemical component } & Number of moles & Batch weight \% \\
\hline Component A & 0.7551 & 63.42 \\
$\mathrm{Al}_{2} \mathrm{O}_{3}$ & 0.0068 & 0.91 \\
$\mathrm{Fe}_{2} \mathrm{O}_{3}$ & 0.0691 & 14.41 \\
$\mathrm{CaO}$ & 0.0346 & 2.53 \\
$\mathrm{MgO}$ & 0.2354 & 12.39 \\
$\mathrm{NaHCO}_{3}$ & 0.0414 & 4.54 \\
$\mathrm{~K}_{2} \mathrm{CO}_{3} \cdot 1.5 \mathrm{H}_{2} \mathrm{O}$ & 0.0028 & 0.60 \\
$\mathrm{Component} \mathrm{B}_{\text {Component C }}$ & 0.0132 & 1.36 \\
\hline
\end{tabular}

Table 7. Batch formula for basalt \#2.

\begin{tabular}{lcc}
\hline \multicolumn{1}{c}{ Chemical component } & Number of moles & Batch weight \% \\
\hline Component $\mathrm{A}$ & 0.687 & 62.07 \\
$\mathrm{Al}_{2} \mathrm{O}_{3}$ & 0.0050 & 0.73 \\
$\mathrm{Fe}_{2} \mathrm{O}_{3}$ & 0.0630 & 14.36 \\
$\mathrm{CaO}$ & 0.0309 & 2.47 \\
$\mathrm{MgO}$ & 0.0216 & 1.24 \\
$\mathrm{NaHCO}_{3}$ & 0.0372 & 4.46 \\
$\mathrm{~K}_{2} \mathrm{CO}_{3} \cdot 1.5 \mathrm{H}_{2} \mathrm{O}$ & 0.0027 & 0.64 \\
$\mathrm{Component}^{\mathrm{B}}$ & 0.0811 & 9.25 \\
Component C & 0.0272 & 4.78 \\
\hline
\end{tabular}


Table 8. Batch formula for basalt \#3.

\begin{tabular}{lcc}
\hline \multicolumn{1}{c}{ Chemical component } & Number of moles & Batch weight \%: \\
\hline Component $\mathrm{A}$ & 0.5917 & 51.36 \\
$\mathrm{Al}_{2} \mathrm{O}_{3}$ & 0.0003 & 0.88 \\
$\mathrm{Fe}_{2} \mathrm{O}_{3}$ & 0.0541 & 11.84 \\
$\mathrm{CaO}$ & 0.0274 & 2.11 \\
$\mathrm{MgO}$ & 0.0192 & 1.06 \\
$\mathrm{NaHCO}_{3}$ & 0.0316 & 3.64 \\
$\mathrm{~K}_{2} \mathrm{CO}_{3} \cdot 1.5 \mathrm{H}_{2} \mathrm{O}$ & 0.0022 & 0.50 \\
$\mathrm{Component}$ & 0.1733 & 18.98 \\
Component C & 0.0570 & 9.63 \\
\hline
\end{tabular}

We have also discovered we can replace part of component $A$ with an inorganic lubricant (see Table 9). This replacement has the following benefits: (a) The inorganic acts as a lubricant (higher green densities and less sticking to metal pressing dies), (b) the inorganic acts as a binder (higher green strengths for handling). These benefits will greatly aid in the green forming of the aggregate when using mass production methods such as briquetting. The uranium oxide powder (or $\mathrm{CeO}_{2}$ surrogate) is mixed with component $\mathrm{A}+$ inorganic lubricant + chemical additives and then pressed and sintered to form DU-AGG of high densities. After melting during the sintering process, the mixture (component $\mathrm{A}+$ inorganic lubricant + the other inorganic compounds listed) is designed to produce a synthetic basalt of the desired composition.

Table 9. Batch formula for \#3 basalt using component $\mathrm{A}+$ inorganic lubricant.

\begin{tabular}{lcc}
\hline \multicolumn{1}{c}{ Chemical component } & Number of moles & Batch weight \% \\
\hline Component $\mathrm{A}$ & 0.2925 & 26.350 \\
Inorganic Lubricant & 0.2686 & 24.295 \\
$\mathrm{Fe}_{2} \mathrm{O}_{3}$ & 0.0837 & 12.089 \\
$\mathrm{CaO}$ & 0.0745 & 3.780 \\
$\mathrm{MgO}$ & 0.0405 & 1.475 \\
$\mathrm{NaHCO}_{3}$ & 0.0232 & 1.761 \\
$\mathrm{~K}_{2} \mathrm{CO}_{3} \cdot 1.5 \mathrm{H}_{2} \mathrm{O}$ & 0.0240 & 3.579 \\
$\mathrm{Component}^{\mathrm{B}}$ & 0.2439 & 17.620 \\
$\mathrm{Component}^{\mathrm{C}}$ & 0.0812 & 9.050 \\
$\mathrm{Al}_{2} \mathrm{O}_{3}$ & & \\
\hline
\end{tabular}


Samples were sintered using the basalt composition \#3 (see Table 9) using an inorganic lubricant. The results are shown in Table 10.

The results in Table 10 show good bulk and apparent densities when using in situ minerals to form the IEB liquid phase and $\mathrm{UO}_{3}$ powder as the starting material. The bulk densities $\left(6.27-6.41 \mathrm{~g} / \mathrm{cm}^{3}\right)$ compare very favorably to those of Table 5 where $\mathrm{UO}_{2}$ was used as a starting material with previously melted and ground IEB as the precursor for the liquid phase (5.91 to $6.88 \mathrm{~g} / \mathrm{cm}^{3}$ ).

Based upon the initial sintering results, it appears that the optimum temperature for our liquid phase sintering process is about $1,250^{\circ} \mathrm{C}$, while normal solid state sintering of $\mathrm{UO}_{2}$ takes place at about $1,700^{\circ} \mathrm{C}$ in a vacuum or hydrogen-containing atmosphere. Costs are reduced in the liquid phase sintering process because of energy savings, and a less complex (inexpensive) sintering furnace can be utilized. Costs are also reduced because inexpensive, naturally occurring minerals are used as precursors to form the liquid phase. These minerals can contain many low level impurities, but since we are not fabricating high-quality nuclear reactor fuel, low level impurities are of little concern. Sintered nuclear reactor fuel (e.g., $\mathrm{UO}_{2}$ ) has to be of a high purity to prevent nuclear activation of various impurities ( $\mathrm{Fe}, \mathrm{B}$, etc.) that either poison the fission process or lead to excessive radiation when the irradiated fuel is removed from the reactor.

\subsection{Improved Sintering of $\mathrm{UO}_{2}$ and $\mathrm{UO}_{3}$ (including use of : hydrogen atmosphere)}

Using the base-line conditions determined in our initial experiments, we conducted additional sintering experiments to further increase the density and also improve the microstructure of the sintered pieces. These experiments included the use of $\mathrm{UO}_{3}$ powder as a starting material, but added the use of dry hydrogen (4\% in argon) to reduce the $\mathrm{UO}_{3}$ to $\mathrm{UO}_{2}$ (see Appendix B) during the sintering process (see Table 11).

Table 10. Sintering results of $\mathrm{UO}_{3}$ plus IEB made in situ from minerals.

\begin{tabular}{ccccccc}
\hline Sample \# & $\begin{array}{c}\mathrm{UO}_{3} \\
\text { content } \\
(\text { vol\%) }\end{array}$ & $\begin{array}{c}\text { Sintering } \\
\text { temperature } \\
\left({ }^{\circ} \text { C/atmosphere }\right)\end{array}$ & $\begin{array}{c}\text { Pressing } \\
\text { pressure } \\
(\mathrm{psi})\end{array}$ & $\begin{array}{c}\text { Bulk } \\
\text { density } \\
\left(\mathrm{g} / \mathrm{cm}^{3}\right)\end{array}$ & $\begin{array}{c}\text { Apparent } \\
\text { density } \\
\left(\mathrm{g} / \mathrm{cm}^{3}\right)\end{array}$ & $\begin{array}{c}\text { Open } \\
\text { porosity } \\
(\%)\end{array}$ \\
\hline 1 & 87 & $1,250 /$ Wet Argon & 20,000 & 6.27 & 6.67 & 5.99 \\
2 & 93 & $1,250 /$ Wet Argon & 20,000 & 6.41 & 6.96 & 7.94 \\
3 & 90 & $1,250 /$ Wet Argon & 20,000 & 6.40 & 6.93 & 7.53 \\
\hline
\end{tabular}


Table 11. Sintering results of $\mathrm{UO}_{3}$ varying temperature and atmosphere.

\begin{tabular}{|c|c|c|c|c|c|c|}
\hline Sample \# & $\begin{array}{l}\mathrm{UO}_{3} \\
\text { content } \\
\text { (vol\%) }\end{array}$ & $\begin{array}{c}\text { Sintering } \\
\text { temperature } \\
\left({ }^{\circ} \mathrm{C} / \text { atmosphere }\right)\end{array}$ & $\begin{array}{l}\text { Pressing } \\
\text { pressure } \\
\text { (psi) }\end{array}$ & $\begin{array}{l}\text { Bulk density } \\
\left(\mathrm{g} / \mathrm{cm}^{3}\right)\end{array}$ & $\begin{array}{l}\text { Apparent } \\
\text { density } \\
\left(\mathrm{g} / \mathrm{cm}^{3}\right)\end{array}$ & $\begin{array}{l}\text { Open } \\
\text { porosity } \\
(\%)\end{array}$ \\
\hline $4-2$ & 93 & $1,250 /$ Wet $\mathrm{H}_{2}$ & 20,000 & 6.27 & 6.59 & 4.78 \\
\hline $5-2$ & 87 & $1,250 /$ Wet $\mathrm{H}_{2}$ & 20,000 & 5.93 & 6.40 & 4.77 \\
\hline $6-2$ & 90 & $1,250 /$ Wet $\mathrm{H}_{2}$ & 20,000 & 6.40 & 6.77 & 5.41 \\
\hline $4-4$ & 93 & $1,250 /$ Dry $\mathrm{H}_{2}$ & 20,000 & 8.10 & 8.62 & 6.02 \\
\hline $5-4$ & 87 & $1,250 / \mathrm{Dry} \mathrm{H}_{2}$ & 20,000 & 7.53 & 7.91 & 4.75 \\
\hline $6-4$ & 90 & $1,250 /$ Dry $\mathrm{H}_{2}$ & 20,000 & 8.05 & 8.58 & 6.13 \\
\hline $4-5$ & 93 & $1,300 /$ Dry $\mathrm{H}_{2}$ & 20,000 & 8.06 & 8.45 & 4.54 \\
\hline $5-5$ & 87 & $1,300 /$ Dry $\mathrm{H}_{2}$ & 20,000 & 7.69 & 8.06 & 4.58 \\
\hline $6-5$ & 90 & $1,300 /$ Dry $\mathrm{H}_{2}$ & 20,000 & 8.28 & 8.71 & 4.99 \\
\hline $4-6$ & 93 & $1,200 /$ Dry $\mathrm{H}_{2}$ & 20,000 & 7.80 & 9.12 & $\begin{array}{c}14.47 \\
\text { (cracks) }\end{array}$ \\
\hline $5-6$ & 87 . & $1,200 /$ Dry $\mathrm{H}_{2}$ & 20,000 & 7.60 & 8.69 & $\begin{array}{c}12.53 \\
\text { (cracks) }\end{array}$ \\
\hline $6-6$ & 90 & $1,200 / \mathrm{Dry} \mathrm{H}_{2}$ & 20,000 & 7.60 & 9.05 & $\begin{array}{c}16.02 \\
\text { (cracks) }\end{array}$ \\
\hline
\end{tabular}

The "wet" atmospheres refer to bubbling the inlet gas through a water bath held at room temperature. This humidifies the gas and causes a higher partial pressure of oxygen in the furnace chamber due to the water dissociation reaction at high temperatures $\left(\mathrm{H}_{2} \mathrm{O} \rightarrow>\mathrm{H}_{2}\right.$ $\left.+1 / 2 \mathrm{O}_{2}\right)$

It is obvious that firing in a dry hydrogen (very reducing/low oxygen partial pressure) atmosphere results in higher bulk and apparent densities while the open porosity remained about the same. Density increase is due to reduction of $\mathrm{U}_{3} \mathrm{O}_{8}$ to the higher density $\mathrm{UO}_{2}$ phase (with accompanying loss of oxygen) by the hydrogen during the sintering process as verified by $\mathrm{X}$-ray diffraction results shown in Table 12 .

The large cracks observed in the $1,200^{\circ} \mathrm{C}$ samples appeared to have originated early in the sintering process because they were open and blunted. The cracks may have originated because trapped gases from uncalcined precursors, organic binders, excess water, or oxygen from the reduction process were unable to escape during the heating. 
Table 12. X-ray diffraction phase analysis of sintered samples.

\begin{tabular}{lccccc}
\hline Sample \# & $\begin{array}{c}\mathrm{U}_{3} \mathrm{O}_{8} \\
\text { relative } \\
\text { abundance }\end{array}$ & $\begin{array}{c}\mathrm{UO}_{2} \text { relative } \\
\text { abundance }\end{array}$ & $\begin{array}{c}\text { Other possible phases } \\
\text { relative abundance }\end{array}$ & $\begin{array}{c}\text { Unidentified } \\
\text { phases }\end{array}$ & $\begin{array}{c}\text { Amorphous } \\
\text { phases }\end{array}$ \\
\hline $4-2$ & $\mathrm{M}^{-78.6 \%}$ & $\mathrm{~m} 14.2 \%$ & $\mathrm{~m} \mathrm{Na}_{4} \mathrm{SiO}_{4} 7.2 \%$ & Yes & Yes \\
$4-3$ & $\mathrm{M} 71.0 \%$ & $\mathrm{~m} 29.0 \%$ & & Yes & Yes \\
$4-4$ & & $\mathrm{M} 100 \%$ & & No & Yes \\
$4-5$ & & $\mathrm{M} 100 \%$ & & Yes & Yes \\
$4-6$ & & $\mathrm{M} 93.2 \%$ & $\mathrm{~m} \mathrm{Mg}_{3} \mathrm{Si}_{4} \mathrm{O}_{10}(\mathrm{OH})_{2} 6.8 \%$ & No & Yes \\
$5-4$ & & $\mathrm{M} 93.4 \%$ & $\mathrm{~m} \mathrm{Mg}_{3} \mathrm{Si}_{4} \mathrm{O}_{10}(\mathrm{OH})_{2} 6.5 \%$ & No & Yes \\
$5-5$ & & $\mathrm{M} 93.6 \%$ & $\mathrm{~m} \mathrm{Mg}_{3} \mathrm{Si}_{4} \mathrm{O}_{10}(\mathrm{OH})_{2} 6.4 \%$ & No & Yes \\
$5-6$ & & $\mathrm{M} 90.8 \%$ & $\mathrm{~m} \mathrm{Mg}_{3} \mathrm{Si}_{4} \mathrm{O}_{10}(\mathrm{OH})_{2} 9.1 \%$ & No & Yes \\
\hline
\end{tabular}

Firing in a dry hydrogen-containing atmosphere increased the density, but did not greatly decrease the open porosity (consistently about $5 \%$ ). This open porosity is shown in the polished sample micrographs of Figure 2. Only a small amount of closed porosity was found in the liquid phase (IEB) sintered samples of the surrogate $\mathrm{CeO}_{2}$ material as shown in. Figure 3. The starting $\mathrm{CeO}_{2}$ powder had a mean particle size of about 1 micron while the particle (agglomerate) size of the $\mathrm{UO}_{3}$ powder was around 90 microns (see Table 2 - sieve analysis). The presence of large, hard powder agglomerates in the $\mathrm{UO}_{3}$ is clearly shown in the polished section micrographs in Figure 4 and Figure 5. These hard agglomerates do not sinter properly because they do not have access to a sufficient amount of IEB liquid phase for wetting of the grain boundaries, and crystallites are strongly locked to one another and cannot rearrange for better packing as is necessary in the first stage of liquid phase sintering. It also appears that the dense clumps remove liquid phase from the other areas and leave worm-like pores behind.

The $\mathrm{UO}_{3}$ powder was ground for 30 minutes by hand using a ceramic mortar and pestal and sintering experiments conducted using the resulting powder. The results are in Table 13 as sample \#9. The result was an increase in both the bulk and apparent densities for this 93 vol\% urania sample. However, the open porosity increased as noted in Table 13. In an attempt to improve the microstructure, the hand-ground $\mathrm{UO}_{3}$ powder was sintered using $20 \mathrm{vol} \% \mathrm{IEB}$. The results are shown as sample \#10 in Table 13. The bulk density increased to our best measured value $\left(8.58 \mathrm{~g} / \mathrm{cm}^{3}\right)$ with a very low amount of open porosity number, which is also reflected in an apparent density of $8.82 \mathrm{~g} / \mathrm{cm}^{3}$ that is fairly close to the bulk density. The closed pore microstructure of sample \#10 is shown in Figure 6.

Some further increase in the densities is predicted if the $\mathrm{UO}_{3}$ powder were finely ground, in a motorized mill, down to a particle size near the value measured for the $\mathrm{CeO}_{2}$ surrogate powder. The theoretical density for 80 vol\% UO $\mathrm{UO}_{2}$ with 20 vol\% IEB is about $9.37 \mathrm{~g} / \mathrm{cm}^{3}$. Therefore, the $8.82-\mathrm{g} / \mathrm{cm}^{3}$ apparent density is $8.82 / 9.37=.94 .1 \%$ of the theoretical (composite) value. In a sintered ceramic body, open porosity is eliminated at about $90-93 \%$ of theoretical density. The 94.1\% of theoretical number is consistent with the microstructure of sample \#10 (mostly closed porosity of the appropriate area fraction). 
Table 13. Sintering of ground $\mathrm{UO}_{3}$ powder + IEB.

\begin{tabular}{ccccccc}
\hline \multirow{2}{*}{$\begin{array}{c}\mathrm{UO}_{3} \\
\text { Sample \# }\end{array}$} & $\begin{array}{c}\text { Sontent } \\
(\text { vol\%) }\end{array}$ & $\begin{array}{c}\text { temperature } \\
\left({ }^{\circ} \mathrm{C} / \text { atmosphere }\right)\end{array}$ & $\begin{array}{c}\text { Pressing } \\
\text { pressure } \\
(\mathrm{psi})\end{array}$ & $\begin{array}{c}\text { Bulk density } \\
\left(\mathrm{g} / \mathrm{cm}^{3}\right)\end{array}$ & $\begin{array}{c}\text { Apparent } \\
\text { density } \\
\left(\mathrm{g} / \mathrm{cm}^{3}\right)\end{array}$ & $\begin{array}{c}\text { Open } \\
\text { porosity } \\
(\%)\end{array}$ \\
\hline 9 & 93 & $1,250 / \mathrm{dry} \mathrm{H}_{2}$ & 20,000 & 8.40 & 9.48 & 11.43 \\
10 & 80 & $1,250 /$ dry $\mathrm{H}_{2}$ & 20,000 & 8.59 & 8.82 & 2.78 \\
\hline
\end{tabular}

\section{CONCLUSIONS}

Uranium oxide powders can be sintered to high densities using iron-enriched basalt (IEB) as a liquid phase forming additive. Effective sintering takes place in the $1,200^{\circ} \mathrm{C}$ to $1,500^{\circ} \mathrm{C}$ range. The preferred sintering temperature is $1,250^{\circ} \mathrm{C}$ to $1,300^{\circ} \mathrm{C}$. The IEB can be formed in situ from a -. combination of finely ground mineral additives (including an inorganic lubricant to aid in green forming of the body). Sintering takes place in oxidizing (air), inert (argon), or reducing (dry hydrogen containing) atmospheres.

Sintering in air or inert atmospheres results in a body that is primarily ( $71 \%$ to $85 \%) \mathrm{U}_{3} \mathrm{O}_{8}$ while sintering in a reducing (dry hydrogen) containing atmosphere results in formation of $90 \%$ to $100 \% \mathrm{UO}_{2}$ phase; using either $\mathrm{UO}_{2}$ or $\mathrm{UO}_{3}$ powders as the starting material. Using 90 vol\% unground $\mathrm{UO}_{3}$ powders and a dry hydrogen atmosphere, sintered samples could be obtained with bulk densities as high as $8.28 \mathrm{~g} / \mathrm{cm}^{3}$ and apparent densities of $8.71 \mathrm{~g} / \mathrm{cm}^{3}$ (open porosity $4.99 \%$ ). Hand grinding of 93 vol\% $\mathrm{UO}_{3}$ powders sintered in dry hydrogen resulting in an increase in bulk density to $8.40 \mathrm{~g} / \mathrm{cm}^{3}$ and apparent density of $9.48 \mathrm{~g} / \mathrm{cm}^{3}$, but with an increase in open porosity to $11.43 \%$. An improvement in the microstructure (reduction in open porosity) was achieved when the vol\% of $\mathrm{UO}_{3}$ was decreased to $80 \%$ (sintering in a dry hydrogen atmosphere). The bulk density increased to $8.59 \mathrm{~g} / \mathrm{cm}^{3}$, the apparent density decreased slightly to $8.82 \mathrm{~g} / \mathrm{cm}^{3}$ (due to increase of low density IEB content), while the open porosity decreased to an excellent number of $2.78 \%$. A representative sample derived from 80 vol\% $\mathrm{UO}_{3}$ showed most pores were closed pores and overall the sample achieved the excellent relative density value of $94.1 \%$ of the estimated theoretical (composite of $\mathrm{UO}_{2}$ and IEB).

Based upon green pressing and sintering experiments using fine surrogate $\mathrm{CeO}_{2}$ starting powder, it is expected that ground $\mathrm{UO}_{3}$ could be successfully mass-produced using the very low cost method of briquetting. 


\section{REFERENCES}

1. Review of Fuel Element Developments for Water Cooled Nuclear Power Reactors, Page 13, Technical Reports Series No. 299, International Atomic Energy Agency, Vienna, 1989.

2. F.P. Knudsen, H.S. Parker, and M.D. Burdick, "Flexural Strength of Specimens Prepared from Several Uranium Dioxide Powders; Its Dependence on Porosity and Grain Size and the Influence of Additions of Titania," J. Am. Ceram. Soc., 43, 12, pp. 641-647 (1960).

3. Private Communication from Collin Caldwell, Babcock \& Wilcox Co., Lynchburg, VA, December 12, 1993.

4. P.A. Lessing, "Development of 'DUCRETE'," INEL-94/0029, Idaho National Engineering Laboratory, Box 1625, Idaho Falls, ID 83415, October 1994.

5. Perry's Chemical Engineers Handbook, pp. 8-64. 


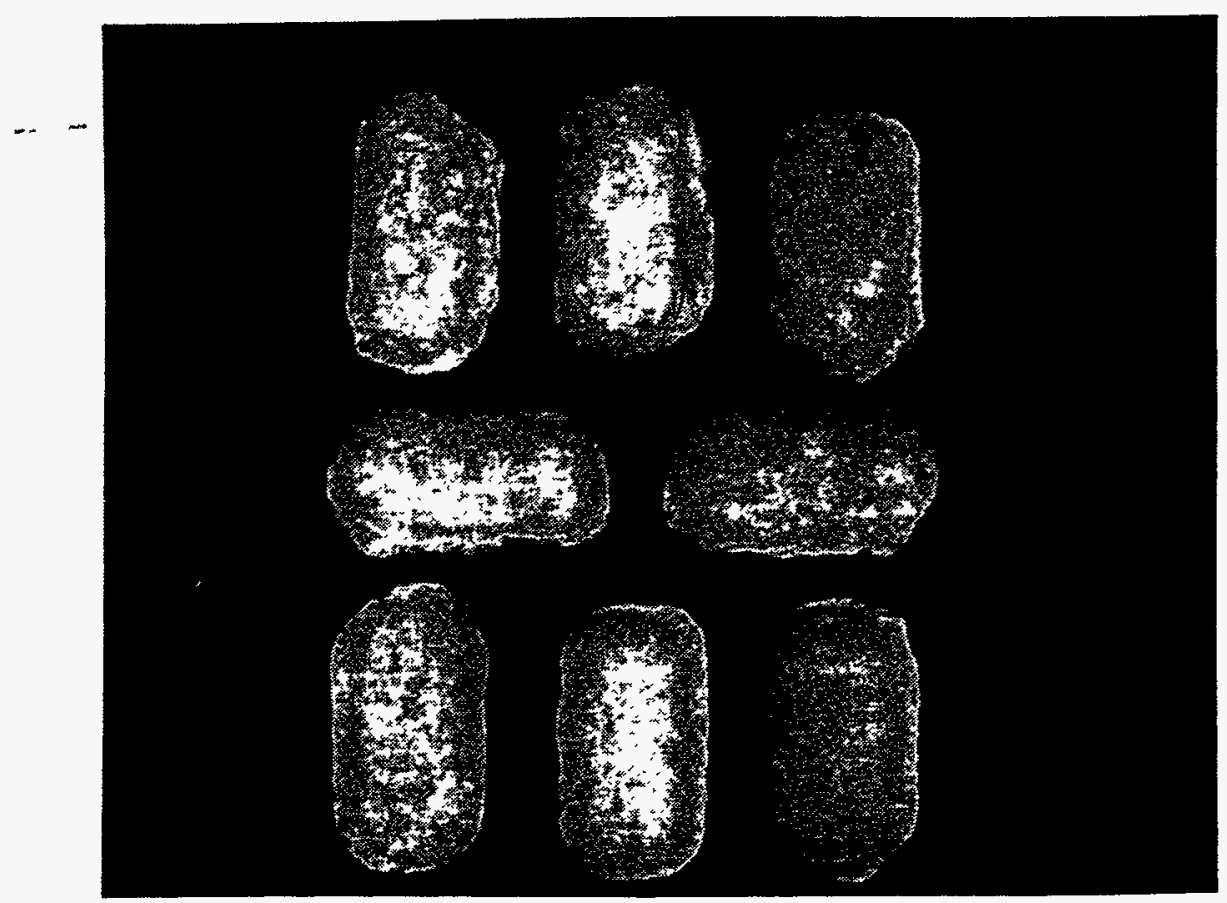

Figure 1. Briquettes of $\mathrm{Ce}_{2}$ sintered using Iron Enriched Basalt additive to from liquid phase.

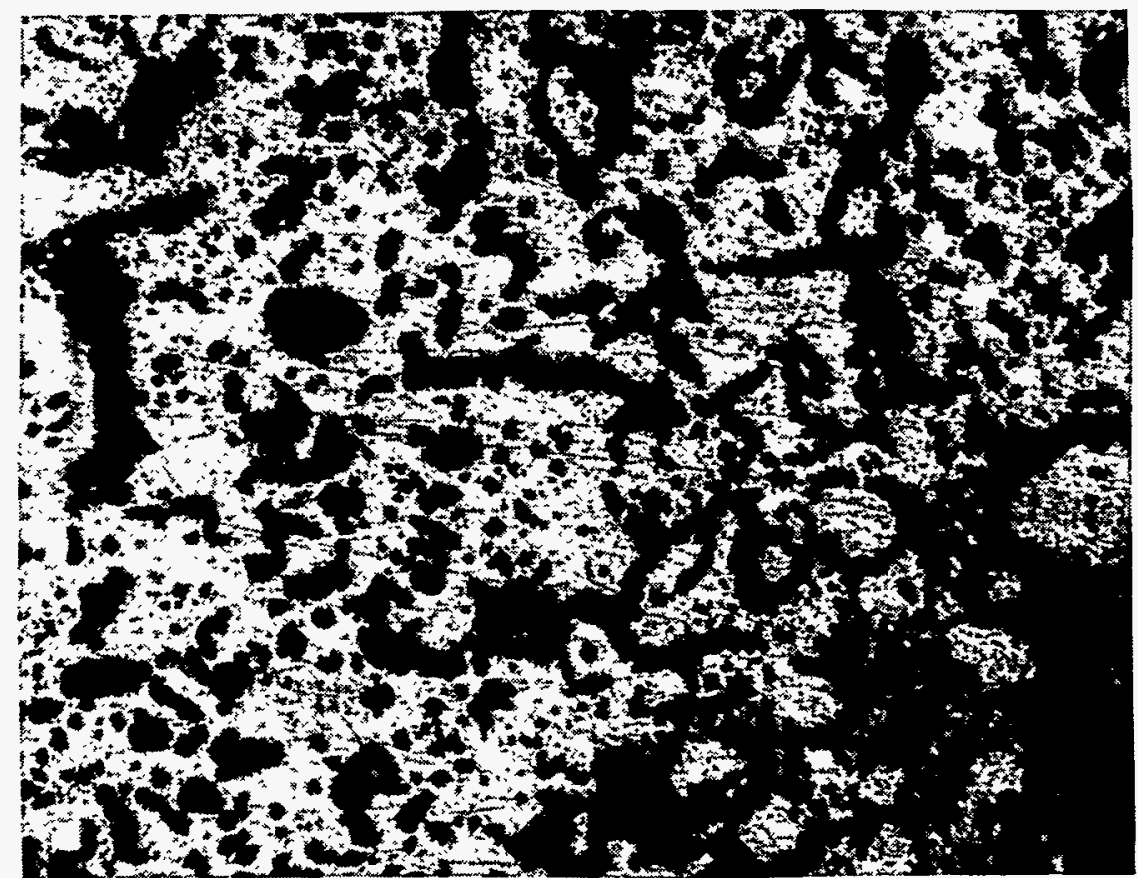

Figure 2a. Micrograph (parallel to pressing direction) of sintered $\mathrm{UO}_{3}$ sample 4-4 (100 X mag). 


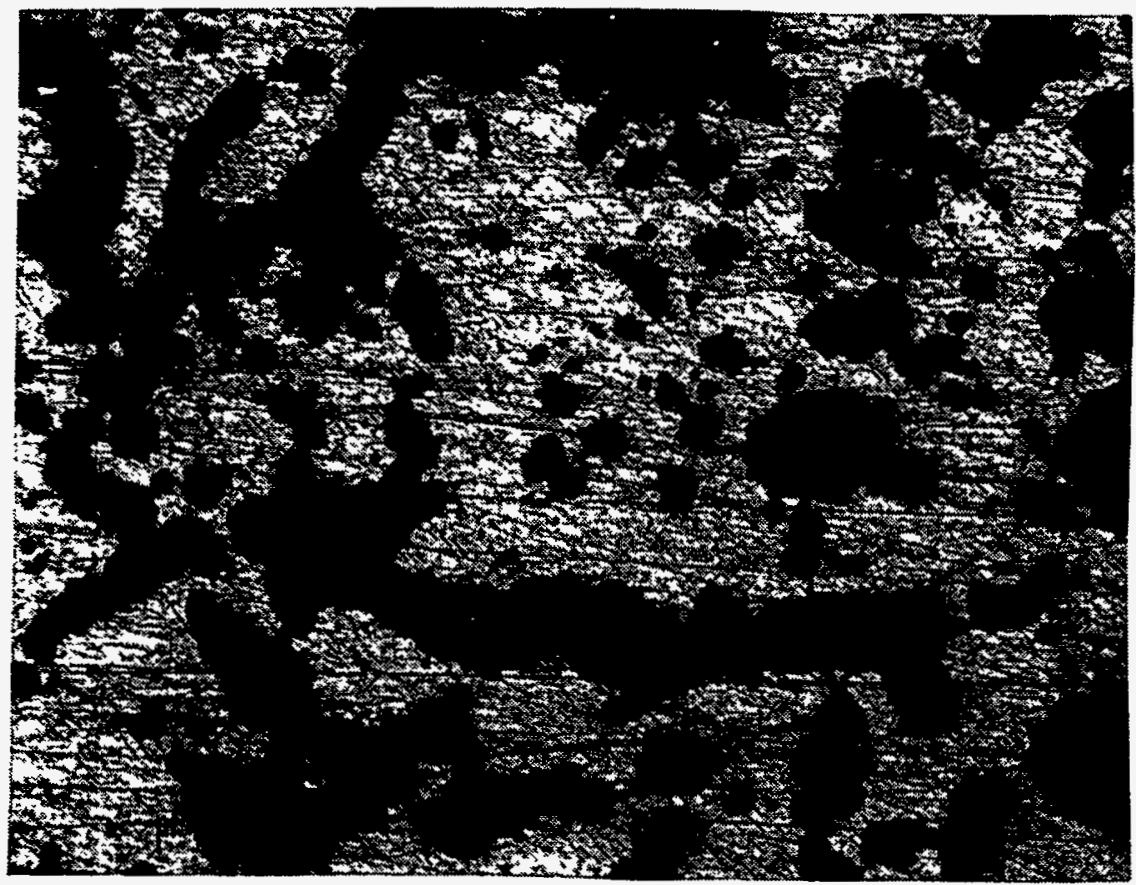

Figure 2b. Micrograph (parallel to pressing direction) of sintered $\mathrm{UO}_{3}$ sample 4-4 (250 X mag).



Figure 2c. Micrograph (perpendicular to pressing direction) of sintered $\mathrm{UO}_{3}$ sample 4-4 (250 X mag). 


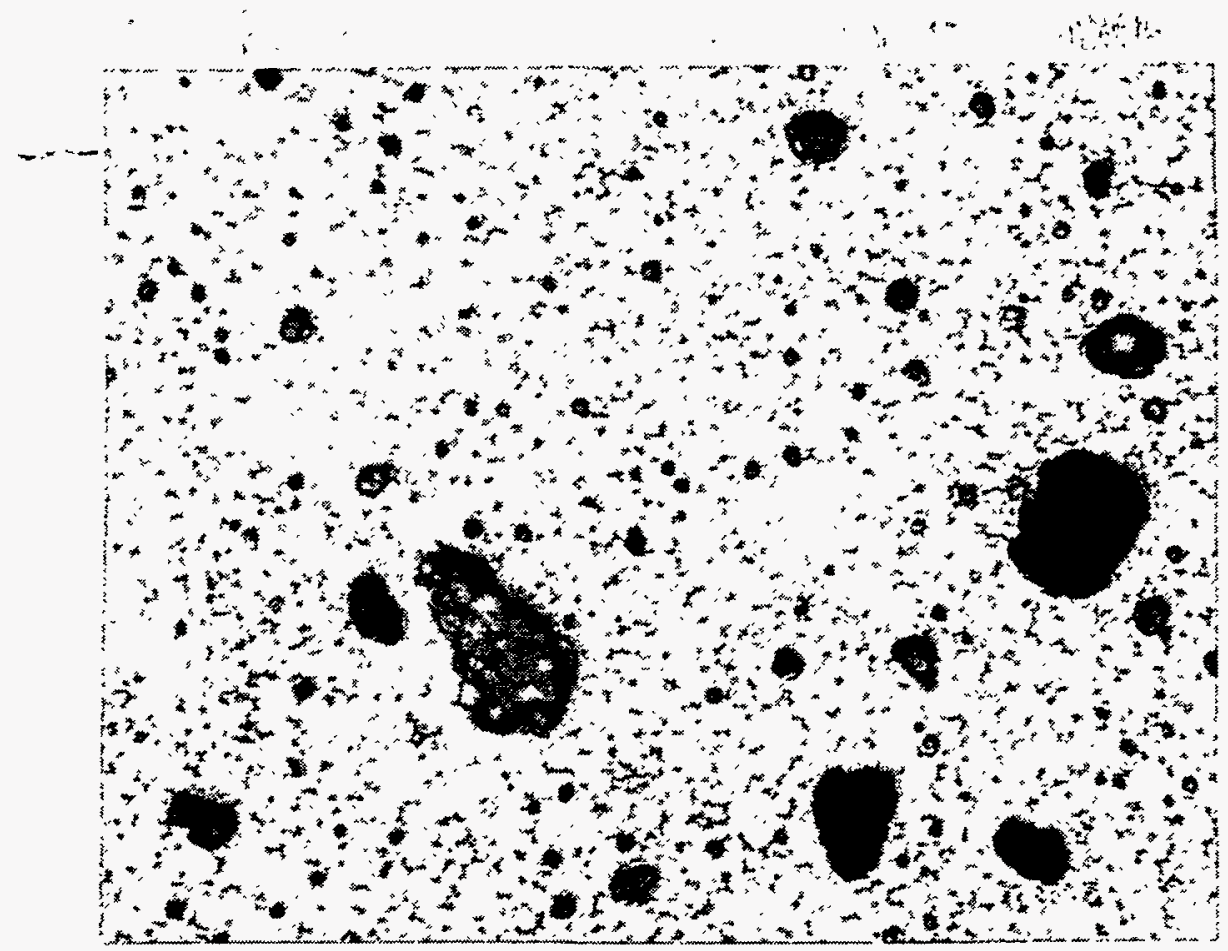

Figure 3a. Micrograph (parallel to pressing direction) of sintered $\mathrm{Ce}_{2}$ sample $2 \mathrm{~A}$ ( $400 \mathrm{X} \mathrm{mag}$ ).

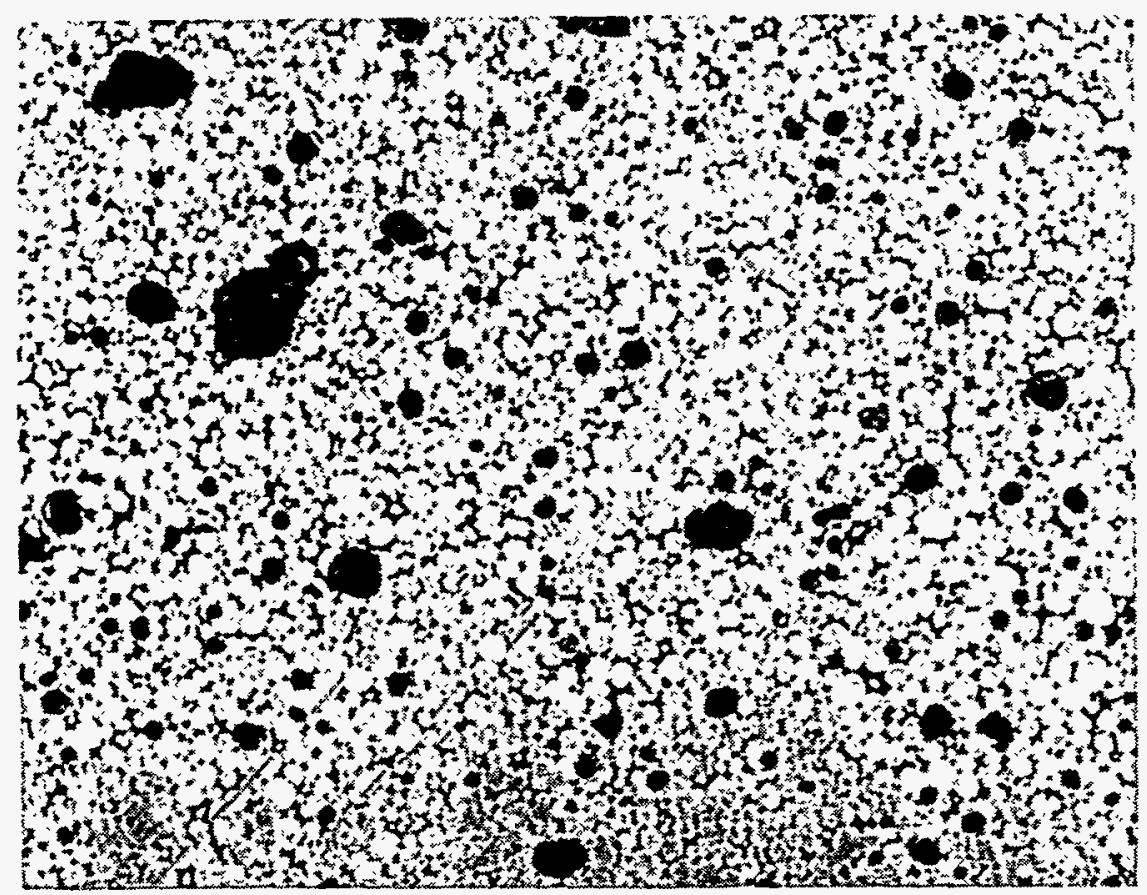

Figure 3b. Micrograph (perpendicular to pressing direction) of sintered $\mathrm{CeO}_{2}$ sample (400 X mag). 


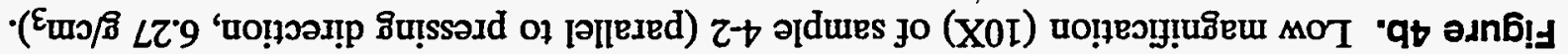

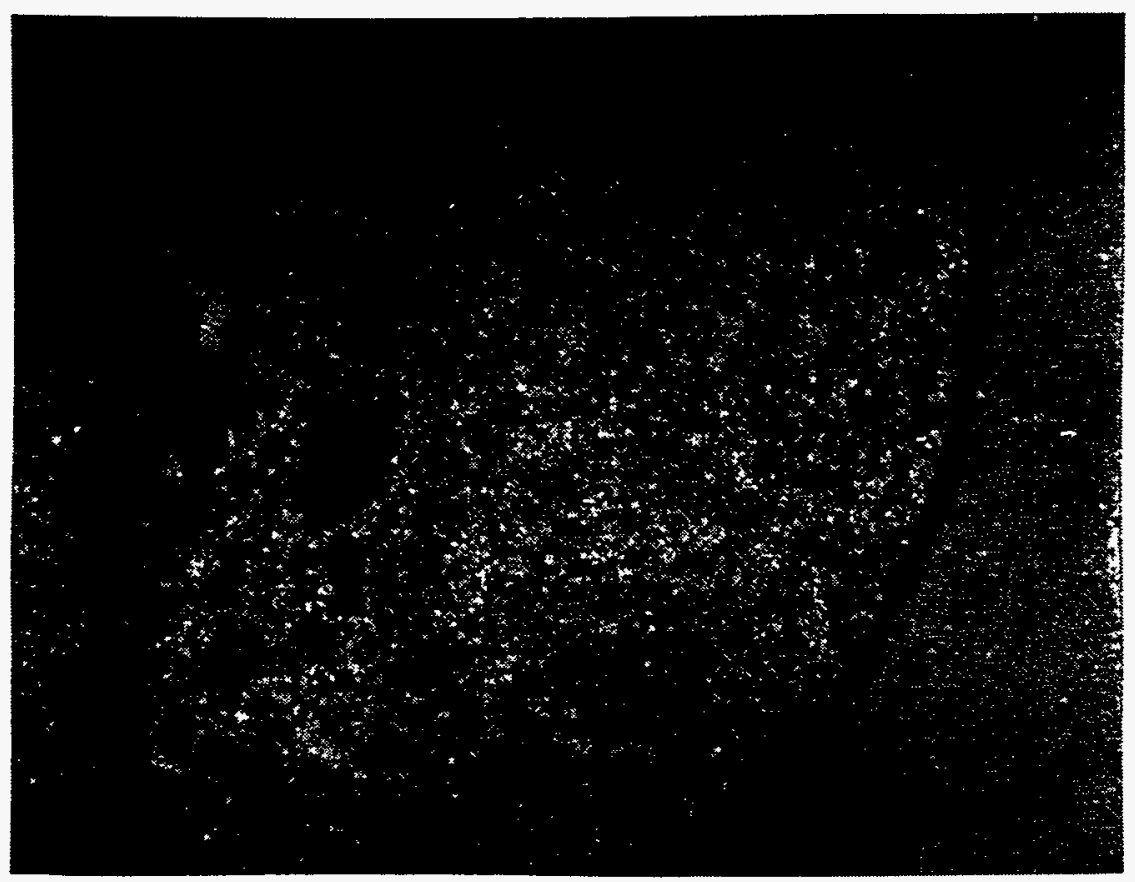

-Ḳ!̣suəp snoəuəs̊owoqu! jo

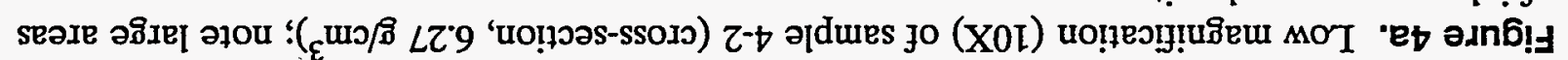






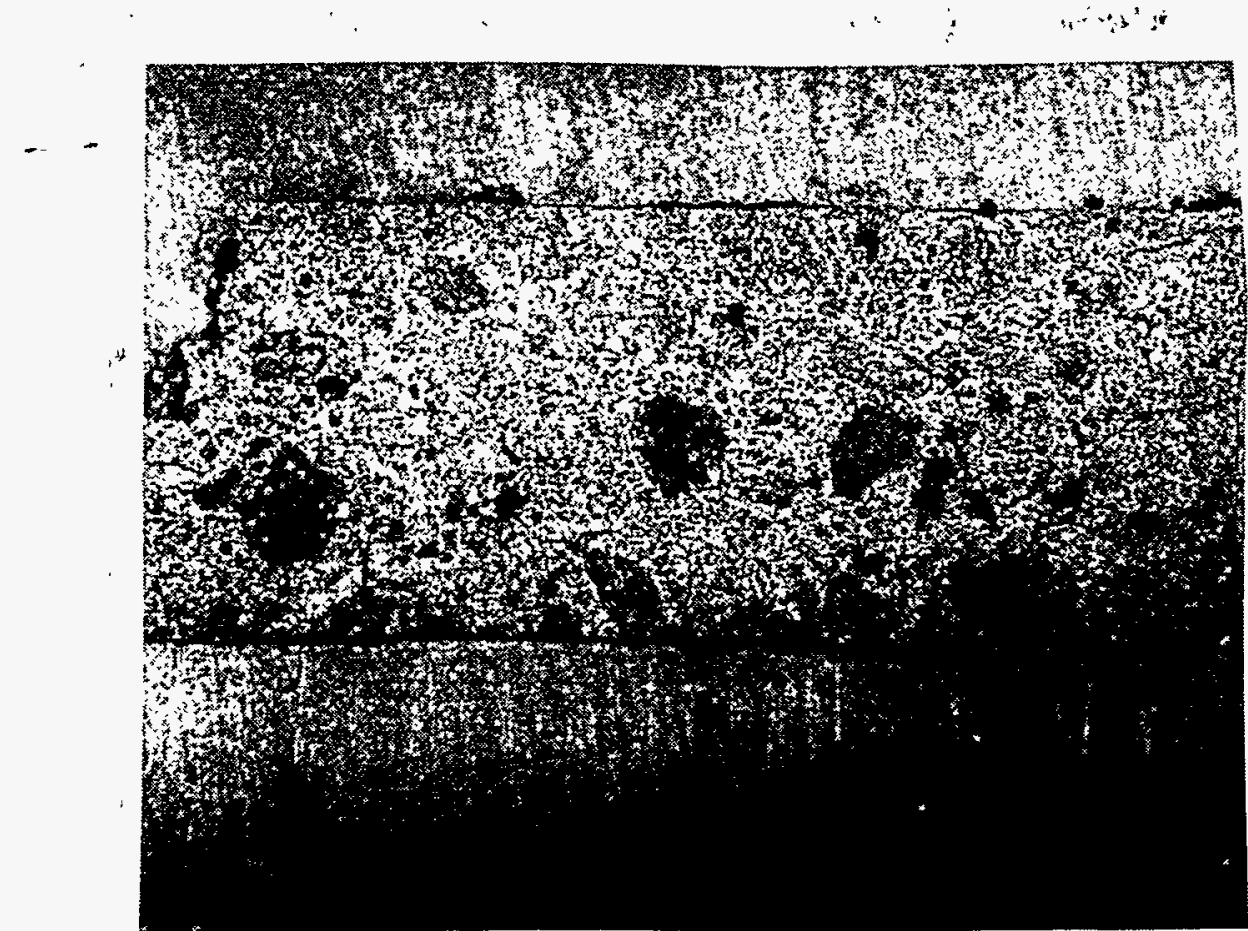

Figure 5a. Low magnification (10X) of sample $6-2$ (cross-section, $6.40 \mathrm{~g} / \mathrm{cm}^{3}, 90$ vol\% $\mathrm{U0}_{3}$ ).

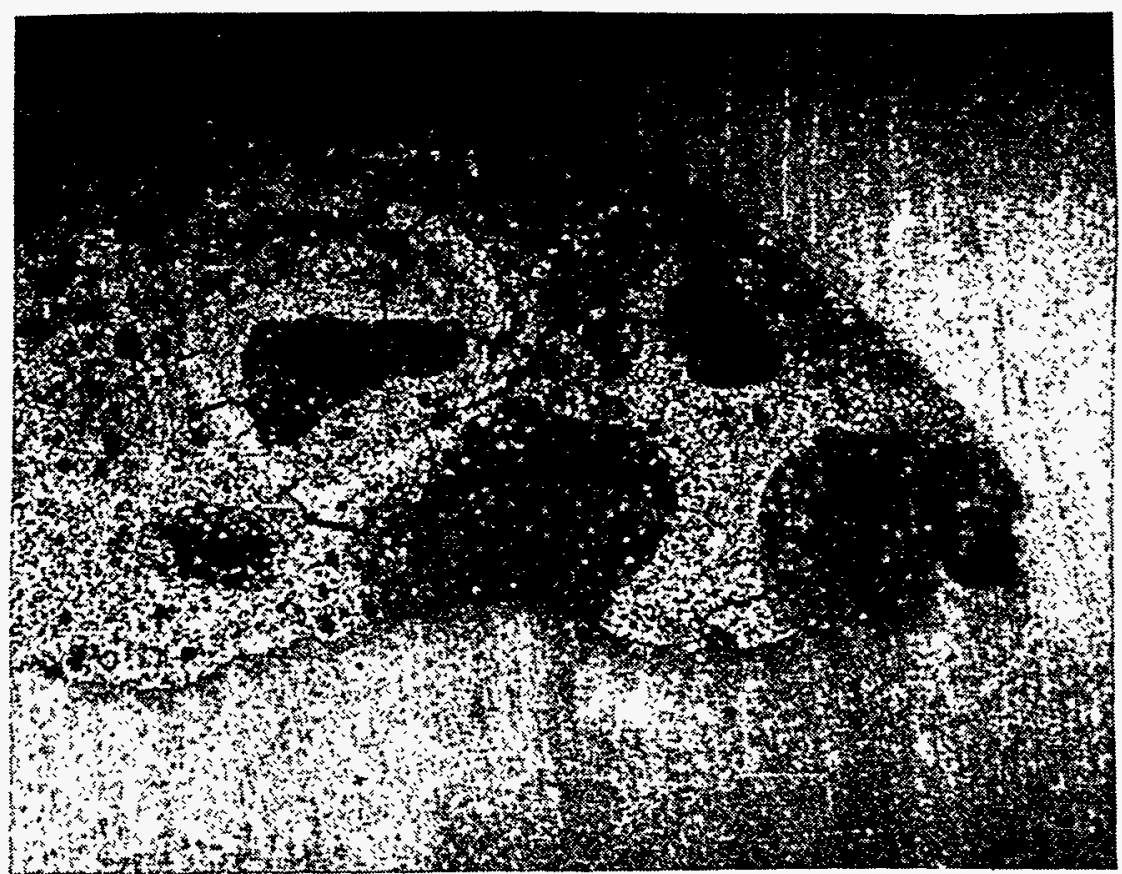

Figure 5b. Low magnification (10X) of sample $6-2$ (parallel to pressing direction, $6.40 \mathrm{~g} / \mathrm{cm}^{3}$, 90 vol\% $\left.\mathrm{UO}_{3}\right)$. 


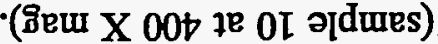

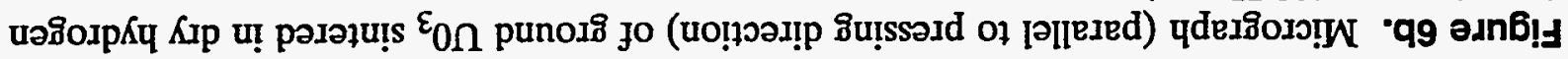

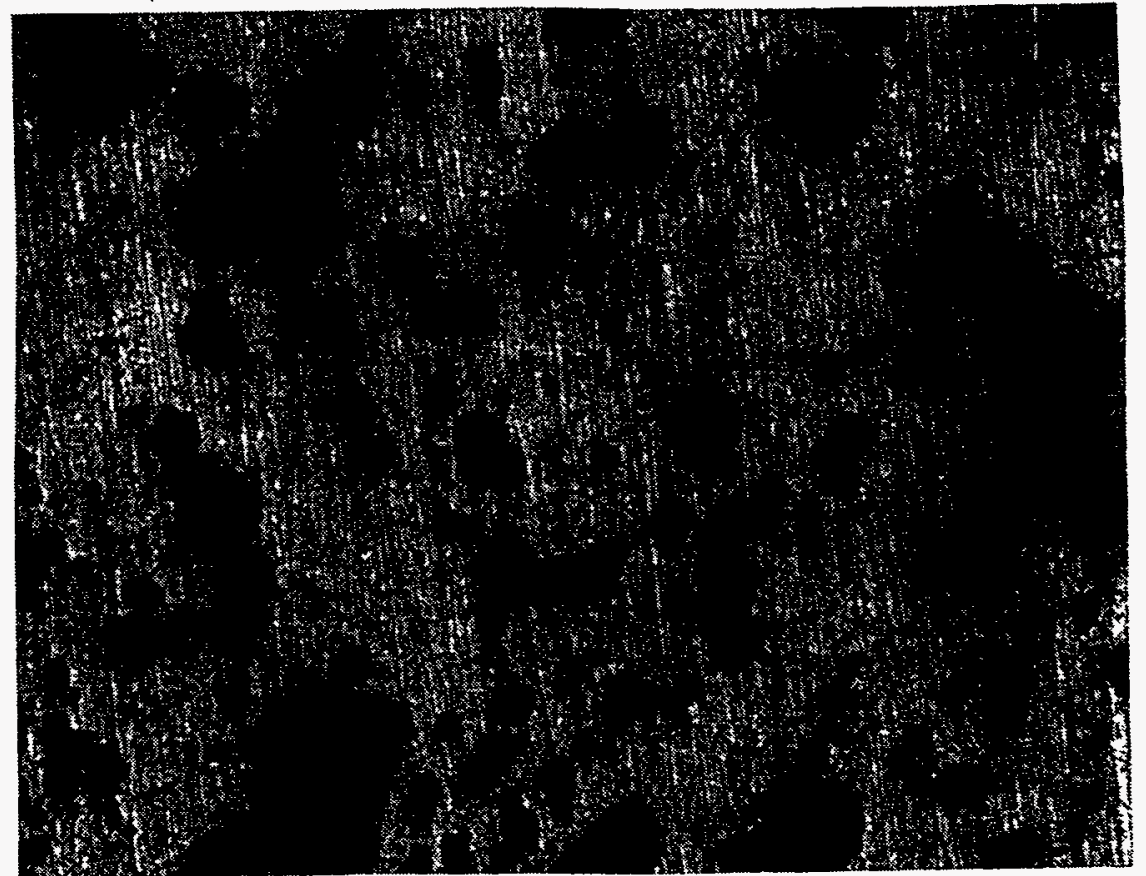

(8̊eu X 0SZ je OI כidmes)






Appendix A

\section{Production of Uranium Oxide Powders from UF $_{6}$}





\section{Appendix A}

\section{Production of Uranium Oxide Powders from UF ${ }_{6}$}

\section{SUMMARY}

Fine particle size $\mathrm{UO}_{2}, \mathrm{UO}_{3}$, or $\mathrm{U}_{3} \mathrm{O}_{8}$ powder are acceptable starting materials for the production of DU-AGG. The use of $\mathrm{UO}_{3}$ is preferred because (a) there is a large amount of surplus depleted $\mathrm{UO}_{3}$ within the DOE system that is available for use and its caretakers are anxious to be rid of it, (b) DU-AGG will have its highest density if the majority the uranium oxide it contains is in the $\mathrm{UO}_{2}$ phase. In order to either convert the initial powdered $\mathrm{UO}_{3}$ into $\mathrm{UO}_{2}$ or maintain an initial $\mathrm{UO}_{2}$ phase during the high-temperature sintering process, it will be necessary to fire in a hydrogen-containing (reducing) atmosphere. Therefore, experiments will be conducted to verify if the $\mathrm{UO}_{3}$ can easily be converted to $\mathrm{UO}_{2}$ (at about $700-900^{\circ} \mathrm{C}$ ) during the sintering thermal cycle. Oxygen gas evolved during the reduction reaction should diffuse out of the DU-AGG prior to formation of the liquid phase. This should prevent bubble formation andkeep the final density of the DU-AGG as high as possible.

\section{DISCUSSION}

\section{Production of $\mathrm{UO}_{2}, \mathrm{U}_{3} \mathrm{O}_{8}$, or $\mathrm{UO}_{3}$ from $\mathrm{UF}_{6}$}

Many different methods have been demonstrated either on a laboratory or industrial scale for the conversion of $\mathrm{UF}_{6}$ to the various uranium oxide phases. The characteristics of these processes are shown in Table A-1.

When starting with $\mathrm{UF}_{6}$, the dry processes will produce $\mathrm{UO}_{2}$ if the final calcination step is conducted between $540^{\circ} \mathrm{C}$ and $760^{\circ} \mathrm{C}$ in a hydrogen-containing atmosphere. If air and/or steam is used in the final calcination step, then either $\mathrm{U}_{3} \mathrm{O}_{8}$ or $\mathrm{UO}_{3}$ will result. For instance, the $\mathrm{UO}_{3}$ phase is the final product if $\mathrm{UO}_{2} \mathrm{~F}_{2}$ is calcined with steam at $425^{\circ} \mathrm{C}-540^{\circ} \mathrm{C}$.

The common "wet" processes (e.g., AUC and ADU) precipitate either an ammonium carbonate or ammonium hydroxide product that is filtered and then calcined. If hydrogen is used during the calcination step, then $\mathrm{UO}_{2}$ results. If air is used during the final calcination step, then either $\mathrm{U}_{3} \mathrm{O}_{8}$ or $\mathrm{OU}_{3}$ results. Using a slow heat to $450^{\circ} \mathrm{C}$ yields $\mathrm{UO}_{3}$; heating to about $800^{\circ} \mathrm{C}$ yields $\mathrm{U}_{3} \mathrm{O}_{8}$.

When uranium (e.g., metal) has been dissolved in nitric acid to form uranium nitrate, it is typically converted to oxide by calcining in air. When performed at $300^{\circ} \mathrm{C}$, this results in the $\mathrm{UO}_{3}$ phase. Using a fluidized bed speeds the process and facilitates a fine size of product. 
Table A-1. Conversion processes for uranium oxides.

\begin{tabular}{|c|c|c|c|}
\hline $\begin{array}{l}\text { Name of } \\
\text { Process }^{(\text {ref })}\end{array}$ & Features of Process & $\begin{array}{l}\text { Produce } \\
\mathrm{UO}_{2} ?\end{array}$ & $\begin{array}{l}\text { Produce } \mathrm{UO}_{3} \\
\text { or } \mathrm{U}_{3} \mathrm{O}_{8} \text { ? }\end{array}$ \\
\hline \multirow[t]{2}{*}{$\begin{array}{l}\text { Dry Process }{ }^{1} \\
\text { same as Double } \\
\text { Cycle Inverse } \\
(D C I)^{2}\end{array}$} & $\begin{array}{l}300-500^{\circ} \mathrm{C} \text { Steam } \\
\text { (1) } \mathrm{UF}_{6}+2 \mathrm{H}_{2} \mathrm{O}->\mathrm{UO}_{2} \mathrm{~F}_{2}+4 \mathrm{HF} \\
\text { (2) } 6 \mathrm{UO}_{2} \mathrm{~F}_{2}+6 \mathrm{H}_{2} \mathrm{O}->2 \mathrm{U}_{3} \mathrm{O}_{8}+12 \mathrm{HF} \\
+\mathrm{O}_{2} \\
\text { or } 3 \mathrm{UO}_{2} \mathrm{~F}_{2}+2 \mathrm{H}_{2} \mathrm{O}->\mathrm{U}_{3} \mathrm{O}_{8}+6 \mathrm{HF}\end{array}$ & & $\begin{array}{l}\text { Oxidation with } \\
\text { steam at } \\
750^{\circ} \mathrm{C} \text { in final } \\
\text { step will } \\
\text { produce } \mathrm{U}_{3} \mathrm{O}_{8}\end{array}$ \\
\hline & $\begin{array}{l}700^{\circ} \mathrm{C} \\
\text { (or 2) } \mathrm{UO}_{2} \mathrm{~F}_{2}+\mathrm{H}_{2}->\mathrm{UO}_{2}+2 \mathrm{HF}\end{array}$ & $\begin{array}{l}\text { Addition of } \\
\mathrm{H}_{2} \text { in final } \\
\text { step will } \\
\text { produce } \\
\mathrm{UO}_{2}\end{array}$ & \\
\hline
\end{tabular}
Dry $\mathrm{UF}_{4}$ process $^{1}$
(1) $\mathrm{UF}_{6}+\mathrm{H}_{2}->\mathrm{UF}_{4}+2 \mathrm{HF}$
(2) $\mathrm{UF}_{4}+2 \mathrm{H}_{2} \mathrm{O} \rightarrow \mathrm{UO}_{2}+4 \mathrm{HF}$

Will produce No $\mathrm{UO}_{2}$, but is reversible and must be carefully controlled
Dry Process ${ }^{3} \quad \mathrm{UO}_{2} \mathrm{~F}_{2}$ with steam at $425-540^{\circ} \mathrm{C}$

$\mathrm{UO}_{2} \mathrm{~F}_{2}$ with steam and air at $540-980^{\circ} \mathrm{C}$

$\mathrm{UO}_{2} \mathrm{~F}_{2}$ with hydrogen at $540-760^{\circ} \mathrm{C}$

High Temp. ${ }^{4}$

Evaporate uranium nitrate hexahydrate

Flame Reactor ${ }^{6}$

Dry Direct

Conversion ${ }^{7}$

Fluidized $\mathrm{Bed}^{8}$ $\approx 1,300^{\circ} \mathrm{C}$

$\mathrm{UF}_{6}+2 \mathrm{H}_{2} \mathrm{O}+\mathrm{H}_{2}->\mathrm{UO}_{2}+6 \mathrm{HF}$

$\mathrm{UF}_{6}$ with hydrogen and oxygen at $1300^{\circ} \mathrm{C}$

$\mathrm{U}\left(\mathrm{NO}_{3}\right)_{2} \cdot 6 \mathrm{H}_{2} \mathrm{O}$ heat $\rightarrow \mathrm{UO}_{3}+2 \mathrm{NO}_{\mathrm{x}}$ $+6 \mathrm{H}_{2} \mathrm{O}$

$500^{\circ} \mathrm{C}$

$3 \mathrm{UF}_{6}+8 \mathrm{NH}_{3}+6 \mathrm{H}_{2} \mathrm{O}->3 \mathrm{UO}_{2}+$ $18 \mathrm{HF}+6 \mathrm{NH}_{3}+\mathrm{N}_{2}$

$\mathrm{UF}_{6}+2 \mathrm{H}_{2} \mathrm{O} \rightarrow \mathrm{UO}_{2} \mathrm{~F}_{2}+4 \mathrm{HF}$

$\mathrm{UO}_{2} \mathrm{~F}_{2}+\mathrm{H}_{2} \rightarrow \mathrm{UO}_{2}+2 \mathrm{HF}$

$\mathrm{UO}_{2} \mathrm{~F}_{2}+2 / 3 \mathrm{H}_{2} \mathrm{O}+1 / 3 \mathrm{H}_{2}->\mathrm{UO}_{2.67}+2 \mathrm{HF}$

$\mathrm{UO}_{2.67}+2 / 3 \mathrm{H}_{2}->\mathrm{UO}_{2}+2 / 3 \mathrm{H}_{2} \mathrm{O}$
$\mathrm{UO}_{3}$

$\mathrm{U}_{3} \mathrm{O}_{8}$

$\mathrm{UO}_{2}$

$\mathrm{UO}_{2}$

$\mathrm{UO}_{3}$

$\mathrm{UO}_{2}$ and $\mathrm{U}_{3} \mathrm{O}_{8}$

$\mathrm{UO}_{2}$

$\mathrm{UO}_{2}$

$$
\mathrm{U}_{3} \mathrm{O}_{8} \text { possible }
$$


Table A-1. (continued).

\begin{tabular}{|c|c|c|c|}
\hline $\begin{array}{l}\text { Name of } \\
\text { Process }^{(\mathrm{ref})}\end{array}$ & Features of Process & $\begin{array}{l}\text { Produce } \\
\mathrm{UO}_{2} ?\end{array}$ & $\begin{array}{l}\text { Produce } \mathrm{UO}_{3} \\
\text { or } \mathrm{U}_{3} \mathrm{O}_{8} \text { ? }\end{array}$ \\
\hline $\begin{array}{l}\text { Ammonium } \\
\text { uranyl carbonate } \\
\text { (AUC) })^{9}\end{array}$ & $\begin{array}{l}\text { (1) } \mathrm{UF}_{6}+2 \mathrm{H}_{2} \mathrm{O}->\mathrm{UO}_{2} \mathrm{~F}_{2}(\mathrm{aq})+4 \mathrm{HF}(\mathrm{aq}) \\
\text { (2) } \mathrm{NH}_{3}+\mathrm{H}_{2} \mathrm{O}->\mathrm{NH}_{4} \mathrm{OH}(\mathrm{aq}) \\
\text { (3) } \mathrm{CO}_{2}+\mathrm{H}_{2} \mathrm{O}->\mathrm{H}_{2} \mathrm{CO}_{3}(\mathrm{aq}) \\
\text { (4) } \mathrm{UO}_{2}+2(\mathrm{aq})+4 \mathrm{NH}_{4}+(\mathrm{aq})+\mathrm{CO}_{3}^{-2}(\mathrm{aq})- \\
> \\
\left(\mathrm{NH}_{4}\right)_{4} \mathrm{UO}_{2}\left(\mathrm{CO}_{3}\right)_{3}(\mathrm{~s}) \\
\text { (5) }\left(\mathrm{NH}_{4}\right)_{4} \mathrm{UO}_{2}\left(\mathrm{CO}_{3}\right)_{3}(\mathrm{~s}) \text { heat- } \\
\mathrm{UO}_{3}(\mathrm{~s})+4 \mathrm{NH}_{3}(\mathrm{~g})+3 \mathrm{CO}_{2}(\mathrm{~g})+2 \mathrm{H}_{2} \mathrm{O}(\mathrm{g}) \\
\text { (6) } \mathrm{UO}_{3}(\mathrm{~s})+\mathrm{H}_{2}(\mathrm{~g}) \text { heat- }>\mathrm{UO}_{2}(\mathrm{~s})+\mathrm{H}_{2} \mathrm{O}(\mathrm{g})\end{array}$ & $\mathrm{UO}_{2}$ & $\mathrm{UO}_{3}$ \\
\hline $\begin{array}{l}\text { Ammonium } \\
\text { diuranate } \\
(\mathrm{ADU})^{10,11,12}\end{array}$ & $\begin{array}{l}\text { (1) } \mathrm{UF}_{6}+2 \mathrm{H}_{2} \mathrm{O}->\mathrm{UO}_{2} \mathrm{~F}_{2}(\mathrm{aq})+4 \mathrm{HF}(\mathrm{aq}) \\
\text { (2) } 2 \mathrm{UO}_{2} \mathrm{~F}_{2}+6 \mathrm{NH}_{4} \mathrm{OH}->\left(\mathrm{NH}_{4}\right)_{2} \mathrm{U}_{2} \mathrm{O}_{7} \\
+\mathrm{H}_{2} \mathrm{O}+4 \mathrm{NH} \\
\text { slow to } 450^{\circ} \mathrm{C} \text { in air } \\
\text { (3) }\left(\mathrm{NH}_{4}\right)_{2} \mathrm{U}_{2} \mathrm{O}_{7} \text { heat- }>2 \mathrm{UO}_{3}+2 \mathrm{NH}_{3} \\
+\mathrm{H}_{2} \mathrm{O} \\
800^{\circ} \mathrm{C} \\
(4) 3\left(\mathrm{NH}_{4}\right)_{2} \mathrm{U}_{2} \mathrm{O}_{7} \text { heat } \rightarrow 2 \mathrm{U}_{3} \mathrm{O}_{8}+ \\
6 \mathrm{NH}_{3}+3 \mathrm{H}_{2} \mathrm{O}+\mathrm{O}_{2}\end{array}$ & & $\begin{array}{l}\mathrm{UO}_{3} \\
\mathrm{U}_{3} \mathrm{O}_{8}\end{array}$ \\
\hline & $\begin{array}{l}(5)\left(\mathrm{NH}_{4}\right)_{2} \mathrm{U}_{2} \mathrm{O}_{7}+2 \mathrm{H}_{2} \text { heat }->2 \mathrm{UO}_{2}+ \\
2 \mathrm{NH}_{3}+3 \mathrm{H}_{2} \mathrm{O}\end{array}$ & $\mathrm{UO}_{2}$ & \\
\hline $\begin{array}{l}\text { Uranium Nitrate } \\
\text { Calcination }^{13}\end{array}$ & $\begin{array}{l}300^{\circ} \mathrm{C} \text { in fluidized bed } \\
\mathrm{U}\left(\mathrm{NO}_{3}\right)_{2}+\text { air } \rightarrow \mathrm{UO}_{3}+2 \mathrm{NO}_{x}\end{array}$ & & $\mathrm{UO}_{3}$ \\
\hline
\end{tabular}

\section{Reduction of $\mathrm{UO}_{3}$ to $\mathrm{UO}_{2}$}

In the $\mathrm{UF}_{6}$ to $\mathrm{UO}_{\mathrm{x}}$ process, there would be a cost savings if air or steam is used in the final calcination step rather than hydrogen. If air/steam is used, the resulting phase would be either $\mathrm{UO}_{3}$ or $\mathrm{U}_{3} \mathrm{O}_{8}$ (depending upon the calcination temperature). Our preference of phase is $\mathrm{UO}_{2}$ because of its higher density $\left(\mathrm{UO}_{2}=10.96 \mathrm{~g} / \mathrm{cm}^{3}, \mathrm{U}_{3} \mathrm{O}_{8}=8.30 \mathrm{~g} / \mathrm{cm}^{3}, \mathrm{UO}_{3}=7.29 \mathrm{~g} / \mathrm{cm}^{3}\right)$.

The question then becomes: $\mathrm{Can} \mathrm{UO}_{3}$ or $\mathrm{U}_{3} \mathrm{O}_{8}$ be reduced to $\mathrm{UO}_{2}$ during the sintering of DU-AGG? Table A-2 summarizes various reduction reactions for uranium oxides.

Table A-2 illustrates that various gases can be used to reduce $\mathrm{UO}_{3}$ and $\mathrm{U}_{3} \mathrm{O}_{8}$ to $\mathrm{UO}_{2}$ at elevated temperatures. These gases include hydrogen, carbon monoxide, methane, and ammonia. The data indicate that $\mathrm{UO}_{3}$ or $\mathrm{U}_{3} \mathrm{O}_{8}$ can be reduced to $\mathrm{UO}_{2}$ using hydrogen at temperatures of about $700^{\circ} \mathrm{C}$ to $800^{\circ} \mathrm{C}$ for times of about 3 hours. 
Table A-2. Reduction processes.

Temperature

Reaction

$\left({ }^{\circ} \mathrm{C}\right)$

Reference

Hydrogen Reuluction of $\mathrm{UO}_{3}$ to $\mathrm{UO}_{2}$ :

$$
\mathrm{UO}_{3}(\mathrm{~s})+\mathrm{H}_{2}(\mathrm{~g})->\mathrm{UO}_{2}(\mathrm{~s})+\mathrm{H}_{2}(\mathrm{~g})
$$

800

5

$\mathrm{UO}_{3}$ from ammonium diuranate $->\mathrm{UO}_{2}$

700 (3 hr)

15

$\mathrm{UO}_{3}$ from uranyl nitrate $->\mathrm{UO}_{2}$

$700(3 \mathrm{hr})$

15

Hydrogen Reduction of $\mathrm{U}_{3} \mathrm{O}_{8}$ to $\mathrm{UO}_{2}$ :

$$
\begin{aligned}
& 1 / 3 \mathrm{U}_{3} \mathrm{O}_{8}(\mathrm{~s})+2 / 3 \mathrm{H}_{2}(\mathrm{~g})->\mathrm{UO}_{2}(\mathrm{~s})+2 / 3 \mathrm{H}_{2} \mathrm{O}(\mathrm{g}) \\
& \mathrm{U}_{3} \mathrm{O}_{8} \text { from } \mathrm{ADU} \text { or } \mathrm{UN}+\mathrm{H}_{2} \rightarrow \mathrm{UO}_{2}
\end{aligned}
$$

800

$700(3 \mathrm{hr})$

5

Hydrogen Reduction of $\mathrm{U}_{3} \mathrm{O}_{8}$ to $\mathrm{UO}_{2}$ :

700

Thermal conversion of $\mathrm{UO}_{3}$ to $\mathrm{U}_{3} \mathrm{O}_{8}$ :

$$
3 \mathrm{UO}_{3} \rightarrow \mathrm{U}_{3} \mathrm{O}_{8}+1 / 2 \mathrm{O}_{2}
$$

Carbon Monoxide Reduction of $\mathrm{UO}_{3}$ :

$$
\mathrm{UO}_{3}+\mathrm{CO} \rightarrow \mathrm{UO}_{2}+\mathrm{CO}_{2}
$$

Methane Reduction of $\mathrm{UO}_{3}$ :

$$
4 \mathrm{UO}_{3}+\mathrm{CH}_{4}->\mathrm{xUO}_{2}+\mathrm{yU}_{3} \mathrm{O}_{8}+\mathrm{CO}_{2}+2 \mathrm{H}_{2} \mathrm{O}
$$

Ammonia Reduction of $\mathrm{UO}_{3}$ or $\mathrm{U}_{3} \mathrm{O}_{8}$ :

$$
\mathrm{UO}_{3}+2 / 3 \mathrm{NH}_{3}(\mathrm{~g})->\mathrm{UO}_{2}+\mathrm{H}_{2} \mathrm{O}(\mathrm{g})+1 / 3 \mathrm{~N}_{2}(\mathrm{~g})
$$

Phase changes take place at various temperatures even without a reducing gas being present. Table A-3 shows that fine $\mathrm{UO}_{2}$ powder is not stable in air at room temperature and will oxidize to $\mathrm{UO}_{2.3}$ or further to $\mathrm{U}_{3} \mathrm{O}_{8}$, depending upon its surface area. At $600^{\circ} \mathrm{C}$ to $700^{\circ} \mathrm{C}, \mathrm{UO}_{3}$ will decompose (in air) to $\mathrm{U}_{3} \mathrm{O}_{8}$. At very high temperatures $\left(21,300^{\circ} \mathrm{C}\right), \mathrm{U}_{3} \mathrm{O}_{8}$ will decompose to $\mathrm{UO}_{2}$. If kept in a neutral or reducing atmosphere, the $\mathrm{UO}_{2}$ can be cooled to room temperature. However, if cooled in air, $\mathrm{UO}_{2}$ will tend to pick up oxygen and revert to $\mathrm{U}_{3} \mathrm{O}_{8}$. Sintering experiments using fine $\mathrm{UO}_{3}$ as a starting powder with IEB should be performed to verify this prediction. 
Table A-3. Oxidation and decomposition processes.

\begin{tabular}{llc}
\hline \multicolumn{1}{c}{ Reaction } & \multicolumn{1}{c}{$\begin{array}{c}\text { Temperature } \\
\left({ }^{\circ} \mathrm{C}\right)\end{array}$} & Reference \\
\hline Very fine $\left(\approx 10 \mathrm{~m}^{2} / \mathrm{g}\right) \mathrm{UO}_{2}$ powder $\rightarrow \mathrm{U}_{3} \mathrm{O}_{8}:$ & 25 & 16 \\
Fine $\left(\approx 5 \mathrm{~m}^{2} / \mathrm{g}\right) \mathrm{UO}_{2}$ powder $\rightarrow \mathrm{UO}_{23}:$ & $25-50$ & 16 \\
Thermal decomposition of $\mathrm{UO}_{3}$ in air: & & 15 \\
$3 \mathrm{UO}_{3} \rightarrow \mathrm{U}_{3} \mathrm{O}_{8}+1 / 2 \mathrm{O}_{2}$ & $600-700$ & \\
Thermal decomposition of $\mathrm{U}_{3} \mathrm{O}_{8}$ in air: & & 15 \\
$\mathrm{U}_{3} \mathrm{O}_{8} \rightarrow 3 \mathrm{UO}_{2}+\mathrm{O}_{2}$ & 1,300 & \\
\hline
\end{tabular}

\section{Liquid Phase Sintering of DU-AGG}

When attempting liquid phase sintering of depleted uranium oxide powders, we might have three basic choices of phases available: $\mathrm{UO}_{2}, \mathrm{U}_{3} \mathrm{O}_{8}$, and $\mathrm{UO}_{3}$. If the $\mathrm{UO}_{2}$ powder is very fine, it may have partially or fully reverted to $\mathrm{UO}_{2.3}$ or $\mathrm{U}_{3} \mathrm{O}_{8}$. The uranium oxide powder is mixed with ground iron-enriched basalt (IEB) powder or other compounds that will melt and convert to the IEB composition at high temperatures. Our sintering work to date has been in the range of $1,200-1,450^{\circ} \mathrm{C}$. Based upon the information in Table A-3, we conclude that $\mathrm{U}_{3} \mathrm{O}_{8}$ will likely be the resultant phase when sintering in air to about $1,250^{\circ} \mathrm{C}$ regardless of whether the starting phase is $\mathrm{UO}_{2}, \mathrm{U}_{3} \mathrm{O}_{8}$, or $\mathrm{UO}_{3}$.

If we want the final sintered product to consist primarily of $\mathrm{UO}_{2}$, then we should sinter in a reducing atmosphere (e.g., hydrogen). Table A-2 shows that if, during the sintering process, we hold the temperature at about $700-900^{\circ} \mathrm{C}$ for about 3 hours, $\mathrm{UO}_{3}$ or $\mathrm{U}_{3} \mathrm{O}_{8}$ will be converted to $\mathrm{UO}_{2}$. This is below the melting point of the IEB and should allow the evolved oxygen to escape from the porous ceramic.such that bubbling should not happen. 


\section{REFERENCES}

1. T.R. Lemons et al., "The Ultimate Disposition of Depleted Uranium," Report K/ETO-44, Martin Marietta, 1990.

2. Review of Fuel Element Developments for Water Cooled Nuclear Power Reactors-Technical, Reports Series No. 299, International Atomic Energy Agency, Vienna, 1989.

3. S.L. Reese and T.C. Runion, "Uranium Processing," U.S. Patent 3,168,369 (February 2, 1965).

4. R.L. Heestand and C.F. Leitten, Jr., "Thermochemical Reduction of Uranium Hexafluoride for the Direct Fabrication of Uranium Dioxide Ceramic Fuels, Nucl. Appl., 1, 584 (1965).

5. Uranium dioxide: Properties and Nuclear Applications, J. Belle, Ed., Division of Reactor Development, USAEC (July 1961).

6. J.I. Federer, W.C. Robinson, Jr., and F.H. Patterson, "Conversion of $\mathrm{UF}_{6}$ to $\mathrm{UO}_{2}$ in a Flame Reactor," Nucl. Appl, 6, 298 (1969).

7. H. Pirk and U. Tillessen, "Process for the Dry Direct Conversion of uranium hexafluoride into sinterable uranium dioxide," Kerntechnik, 12, 3, 117 (Jahrgang 1970).

8. K.C. Radford, W. L. Lyon, and J.E. Hart, "Fluid-Bed Conversion of $\mathrm{UF}_{6}$ to $\mathrm{UO}_{2}$, , Am. Ceram. Soc. Bull, 58, No. 2, 219 (1979).

9. M-C Lee and C-J Wu, "Conversion of $\mathrm{UF}_{6}$ to $\mathrm{U0}_{2}$ : A quasi-optimization of the ammonium uranyl carbonate process," J. of Nucl. Mater., 185, 190 (1991).

10. H.K. Roffman, "Environmental Impacts of the 'Front End' of the Nuclear Energy Cycle," Proceedings-Institute of Environmental Sciences, 191.

11. Westinghouse Environmental Systems Department, Environmental Evaluation for Westinghouse Nuclear Fuels Division, Columbia, South Carolina, March 1, 1975.

12. J.I. Federer, W.C. Robinson, Jr. and F.H. Patterson, "Conversion of $\mathrm{UF}_{6}$ to $\mathrm{UO}_{2}$ in a Flame Reactor," Nuclear Appl, 6, 298 (1969).

13. Personal Communication from J.M. Taylert of WINCO, April 20, 1994, providing information from document PSD7-3A/NC/DSA.

14. H. Vietzke, "Conversion of Uranium Hexafluoride to Uranium Dioxide," Kerntechnik, 6, 176 (April 1964).

15. Uranium Production Technology, C.D. Harrington and A.E. Ruehle, eds., D. Van Nostrand Co.

16. The Chemistry of Uranium, E.H.P. Cordfunke, Elsevier Publishing Co., 73 (1969). 
Appendix B

\section{High-Temperature Stability of "DUCRETE" with $\mathrm{UO}_{2}$ and $\mathrm{UO}_{3}$ Large Aggregate}





\section{Appendix B}

\section{High-Temperature Stability of "DUCRETE" with $\mathrm{UO}_{2}$ and $\mathrm{UO}_{3}$ Large Aggregate}

\section{INTRODUCTION}

Development of concrete that utilizes ceramic forms of depleted uranium oxide as the aggregate is under development at the Idaho National Engineering Laboratory. ${ }^{1}$ Part of the investigation is to determine the elevated temperature stability of this concrete. Samples were mixed using the cement:sand:aggregate mass ratios shown in Table B-1.

Depleted $\mathrm{UO}_{2}$ pellets were received from Oak Ridge National Laboratory (ORNL) in stainless steel tubing. These pellets were sintered very dense with a hard smooth surface, and were $0.25 \mathrm{in}$. in diameter and $0.5 \mathrm{in}$. long. Crushed gravel aggregate was obtained locally and screened to a minus 0.325 -in. to plus 4 mesh (0.110-in.) size fraction for use in the reference samples. This gravel was very irregular in shape with rough surfaces. Depleted $\mathrm{U}_{3} \mathrm{O}_{8}$ was received as dense sintered plates ( 0.25 in. thick) from Argonne National Laboratory-West. The plates were fractured into irregular, block-like pieces and screened to a minus 0.25 -in. to plus 4 mesh size fraction. All of the concrete samples were cured for 7 days at room temperature prior to the high-temperature exposure. The concrete samples were placed in a rack of an environmental chamber. A flowing atmosphere of humidified air was provided. The air was humidified by bubbling through water held at room temperature. Since the chamber was not completely sealed, the pressure was not allowed to exceed one atmosphere of pressure, and therefore at temperatures over approximately $100^{\circ} \mathrm{C}$, the exposure was to unsaturated steam (pressures did not follow the steam tables). The strength of the samples was measured using standard compression and Brazilian tensile type tests.

Table B-1 gives the strength test results after the elevated temperature exposure. There was no visual damage to any of the concretes at temperatures between $90^{\circ} \mathrm{C}$ and $150^{\circ} \mathrm{C}$. When exposed at $250^{\circ} \mathrm{C}$ for 14 days, there was no visual damage to the reference concrete but the DUCRETE made with $\mathrm{U}_{3} \mathrm{O}_{8}$ aggregate cracked. The damage at $250^{\circ} \mathrm{C}$ for 14 days to the $\mathrm{UO}_{2}$ DUCRETE was severe, and the DUCRETE crumbled to the bottom of the chamber. The $\mathrm{UO}_{2}$ pellets were integral and solid, but the surface changed from brown to a dusty appearing black color.

The high-temperature exposure study was considered to be an "oxidation" test because of the easy access of air and water vapor to the aggregate through the open pores of the cement. There was water vapor available from water not reacted to form calcium silicate hydrate compounds and from water vapor in the atmosphere. However, it was not known if the cracking and spalling of the concrete was due to oxidation (volume increase) at the surface of the uranium oxide aggregate or some type of chemical reaction with the constituents of the portland cement. 
Table B-1. Concrete properties - oxidation study.

\begin{tabular}{|c|c|c|c|c|c|c|}
\hline $\begin{array}{l}\text { Aggregate } \\
\text { type }\end{array}$ & $\begin{array}{l}\text { Mass } \\
\text { ratio of } \\
\text { mixture }\end{array}$ & $\begin{array}{l}\mathrm{W} / \mathrm{C} \\
\text { ratio }\end{array}$ & $\begin{array}{l}\text { (PSI- } 400 N) \\
\text { oz/100\# of } \\
\text { cement }\end{array}$ & $\begin{array}{l}\text { Density } \\
\left(\mathrm{g} / \mathrm{cm}^{3}\right)\end{array}$ & $\begin{array}{l}\text { Compressive } \\
\text { strength/standard } \\
\text { deviation } \\
\text { (psi) }\end{array}$ & $\begin{array}{l}\text { Brazilian test } \\
\text { tensile strength/ } \\
\text { standard deviation } \\
\text { (psi) }\end{array}$ \\
\hline Gravel & $\begin{array}{l}\text { 1:1.5:3.5 } \\
7 \text { day } \\
\text { R.T. }\end{array}$ & 0.400 & 2.948 & 2.21 & $4,562 / 43$ & 449.3 / 41 \\
\hline $\mathrm{UO}_{2}$ & $\begin{array}{l}\text { 1:1.5:14.2 } \\
7 \text { day } \\
\text { R.T. }\end{array}$ & 0.450 & 2.947 & 6.27 & $4,228 / 424$ & $359.3 / 126$ \\
\hline Gravel & $\begin{array}{l}\text { 1:1.5:3.5 } \\
14 \text { day } \\
90^{\circ} \mathrm{C}\end{array}$ & 0.401 & 2.993 & & 4,458 / 1685 & \\
\hline $\mathrm{UO}_{2}$ & $\begin{array}{l}\text { 1:1.5:14.2 } \\
14 \text { day } \\
90^{\circ} \mathrm{C}\end{array}$ & 0.450 & 2.947 & & $4,649 / 765$ & $650.5 / 15$ \\
\hline Gravel & $\begin{array}{l}1: 1.5: 3.5 \\
28 \text { day } \\
90^{\circ} \mathrm{C}\end{array}$ & 0.401 & 2.993 & & $5,037 / 628$ & \\
\hline $\mathrm{UO}_{2}$ & $\begin{array}{l}\text { 1:1.5:14.2 } \\
28 \text { day } \\
90^{\circ} \mathrm{C}\end{array}$ & 0.450 & 2.947 & & $4,246 / 2058$ & $604.5 / 88$ \\
\hline Gravel & $\begin{array}{l}1: 1.5: 3.5 \\
14 \text { day } \\
125^{\circ} \mathrm{C}\end{array}$ & 0.401 & 2.993 & & $5,169 / 8$ & \\
\hline $\mathrm{UO}_{2}$ & $\begin{array}{l}\text { 1:1.5:14.2 } \\
14 \text { day } \\
125^{\circ} \mathrm{C}\end{array}$ & 0.450 & 2.947 & & $4,947 / 600$ & $557.5 / 29$ \\
\hline Gravel & $\begin{array}{l}\text { 1:1.5:3.5 } \\
28 \text { day } \\
125^{\circ} \mathrm{C}\end{array}$ & 0.401 & 2.993 & & $3,937 / 647$ & \\
\hline $\mathrm{UO}_{2}$ & $\begin{array}{l}1: 1.5: 14.2 \\
28 \text { day } \\
125^{\circ} \mathrm{C}\end{array}$ & 0.405 & 2.947 & & $3,035 / 684$ & $556.0 / 50$ \\
\hline Gravel & $\begin{array}{l}1: 1.5: 3.5 \\
14 \text { day } \\
150^{\circ} \mathrm{C}\end{array}$ & 0.401 & 2.993 & & $5,217 / 349$ & \\
\hline
\end{tabular}


Table B-1. (continued).

\begin{tabular}{|c|c|c|c|c|c|c|}
\hline $\begin{array}{l}\text { Aggregate } \\
\text { type }\end{array}$ & $\begin{array}{l}\text { Mass } \\
\text { ratio of } \\
\text { mixture }\end{array}$ & $\begin{array}{l}\mathrm{W} / \mathrm{C} \\
\text { ratio }\end{array}$ & $\begin{array}{l}\text { (PSI-400N) } \\
\text { oz/100\# of } \\
\text { cement }\end{array}$ & $\begin{array}{l}\text { Density } \\
\left(\mathrm{g} / \mathrm{cm}^{3}\right)\end{array}$ & $\begin{array}{l}\text { Compressive } \\
\text { strength/standard } \\
\text { deviation } \\
\text { (psi) }\end{array}$ & $\begin{array}{l}\text { Brazilian test } \\
\text { tensile strength/ } \\
\text { standard deviation } \\
\text { (psi) }\end{array}$ \\
\hline $\mathrm{UO}_{2}$ & $\begin{array}{l}1: 1.5: 14.2 \\
14 \text { day } \\
150^{\circ} \mathrm{C}\end{array}$ & 0.405 & 2.947 & & $\cdot 3,479 / 737$ & $658.5 / 16$ \\
\hline Gravel & $\begin{array}{l}1: 1.5: 3.5 \\
28 \text { day } \\
150^{\circ} \mathrm{C}\end{array}$ & 0.401 & 2.993 & & $5,435 / 177$ & \\
\hline $\mathrm{UO}_{2}$ & $\begin{array}{l}\text { 1:1.5:14.2 } \\
28 \text { day } \\
150^{\circ} \mathrm{C}\end{array}$ & 0.405 & 2.947 & & $3,785 / 1351$ & $639.0 / 5$ \\
\hline Gravel & $\begin{array}{l}\text { 1:1.5:3.5 } \\
14 \text { day } \\
250^{\circ} \mathrm{C}\end{array}$ & 0.401 & 2.993 & & $3,271 / 554$ & \\
\hline $\mathrm{UO}_{2}$ & $\begin{array}{l}1: 1.5: 14.2 \\
14 \text { day } \\
250^{\circ} \mathrm{C}\end{array}$ & 0.405 & 2.947 & $\mathrm{NA}$ & Disintegrated & \\
\hline $\mathrm{U}_{3} \mathrm{O}_{8}$ & $\begin{array}{l}1: 1.5: 10 \\
14 \text { day } \\
250^{\circ} \mathrm{C}\end{array}$ & 0.500 & 2.984 & NA & Deep Cracks & \\
\hline
\end{tabular}

During the curing process of portland cement, $\mathrm{Ca}(\mathrm{OH})_{2}$ is evolved that could react with the outer surface of the aggregate. Examples of this type of proposed reaction are given by Equation (1) or Equation (2), below.

$\mathrm{U}_{3} \mathrm{O}_{8}+2 \mathrm{Ca}(0 \mathrm{H})_{2}->2 \mathrm{CaUO}_{4}+\mathrm{UO}_{2}+\mathrm{H}_{2}$

$\mathrm{UO}_{2}+\mathrm{Ca}(\mathrm{OH})_{2}-\rightarrow \mathrm{CaUO}_{4}+\mathrm{H}_{2}$

The crystal (theoretical) density of $\mathrm{UO}_{2}$ is $10.96 \mathrm{~g} / \mathrm{cm}^{3}$, the crystal density of $\mathrm{U}_{3} \mathrm{O}_{8}$ is $8.30 \mathrm{~g} / \mathrm{cm}^{3}$, and the crystal density of $\mathrm{UO}_{3}$ is $7.29 \mathrm{~g} / \mathrm{cm}^{3}$. If the surface of $\mathrm{UO}_{2}$ aggregate is oxidized and converts to a lower density phase (e.g., $\mathrm{U}_{3} \mathrm{O}_{8}$ ), the crystal lattice will expand and result in severe stresses within the surface layer of the aggregate and within adjacent layers of the portland cement. 
The purpose of this current study is to examine the "DUCRETE" and to clarify the mechanism(s) whereby the DUCRETE's strength is degraded and, ultimately, why the aggregate disintegrates.

\section{EXPERIMENTAL}

Samples were taken from DUCRETE, shown in Table B-1. These samples were prepared for SEM analysis and identified as shown in Table B-2. Pieces approximately 0.5 to 0.75 in. were cut from the DUCRETE, cast into 1.5-in. diameter plastic metallography mounts, ground, and polished flat. Three modes of SEM analysis were conducted on these samples: (a) secondary electron emission (normal) imaging, (b) backscatter emission electron imaging, and (c) energy dispersive spectroscopy (EDS with XPP quantitation); semi-quantitative using $\mathrm{ThO}_{2}$ and $\mathrm{UO}_{2}$ (as fabricated) polished surfaces as standards. The backscatter mode shows illuminated intensity according to atomic number and is particularly useful in identifying phases, reaction zones, inclusions, etc. The EDS analysis gives elemental compositions by weight and atomic percent. This analysis works best with a flat surface (provided by our polished specimens), and since the beam penetrates into the volume of the material, there is a possibility of erratic data when analyzing at the edge of a material. All results were the average of analysis taken for at least three individual spots; the standard deviations were calculated and provided as part of the data.

Table B-2. Samples analyzed using SEM.

\begin{tabular}{cccc}
\hline Sample \# & $\begin{array}{c}\text { Exposure temperature } \\
\left({ }^{\circ} \mathrm{C}\right)\end{array}$ & $\begin{array}{c}\text { Exposure time } \\
\text { (days) }\end{array}$ & $\begin{array}{c}\text { Aggregate phase } \\
\text { at time }=0\end{array}$ \\
\hline 11 & 90 & 14 & $\mathrm{UO}_{2}$ \\
12 & 90 & 14 & $\mathrm{UO}_{2}$ \\
6 & 90 & 28 & $\mathrm{UO}_{2}$ \\
7 & 90 & 28 & $\mathrm{UO}_{2}$ \\
13 & 125 & 14 & $\mathrm{UO}_{2}$ \\
14 & 125 & 14 & $\mathrm{UO}_{2}$ \\
15 & 125 & 28 & $\mathrm{UO}_{2}$ \\
16 & 125 & 28 & $\mathrm{UO}_{2}$ \\
9 & 150 & -14 & $\mathrm{UO}_{2}$ \\
10 & 150 & 14 & $\mathrm{UO}_{2}$ \\
4 & 150 & 28 & $\mathrm{UO}_{2}$ \\
5 & 150 & 28 & $\mathrm{UO}_{2}$ \\
8 & 150 & 28 & $\mathrm{UO}_{2}$ \\
3 & 250 & 14 & $\mathrm{UO}_{2}$ \\
1 & 250 & 14 & $\mathrm{U}_{3} \mathrm{O}_{8}$ \\
2 & 250 & 14 & $\mathrm{U}_{3} \mathrm{O}_{8}$ \\
\hline
\end{tabular}


Additionally, "bare" uranium oxide aggregate (unencapsulated by portland cement) samples were exposed to the same high-temperature conditions as the DUCRETE. These samples were characterized by dimensional changes $( \pm 0.0001 \mathrm{in}$.) and weight changes $( \pm 0.05 \mathrm{~g})$. Resulting volume and density changes were calculated.

\section{RESULTS}

Figure $\mathrm{B}-1$ shows a normal image of sample $\mathrm{UO}_{2}-11\left(90^{\circ} \mathrm{C}\right.$ for 14 days) while Figure $\mathrm{B}-2$ shows the backscatter image of the same area (the $\mathrm{UO}_{2}$ is at the bottom of the photograph). There is no evidence of reactions. Figure B-3 shows a crack in the cement near the interface. This may be a result of the polishing process or evidence of stresses. Figure B-4 shows a normal image of sample $\mathrm{UO}_{2}-07\left(90^{\circ} \mathrm{C}\right.$ for 28 days). The $\mathrm{UO}_{2}$ is to the left and the cement plus sand is to the right of the photograph. The $\mathrm{UO}_{2}$ aggregate appears to well bonded. Figure B-5 shows a backscatter emission image of the same area. There are a few very small chips along the $\mathrm{UO}_{2}$ cement interface, but there is no evidence of reaction zones or precipitates. Figure B-6 shows the $\mathrm{UO}_{2}$ /cement interface for sample $\mathrm{UO}_{2}-14\left(125^{\circ} \mathrm{C}\right.$ for 14 days), while Figure $\mathrm{B}-7$ shows the corresponding area in backscatter mode. There is a $\mathrm{UO}_{2}$ chip in the cement, but nothing unusual was found at the interface. Figure B-8 shows the spots where EDS analysis was conducted at the edge.

Figure B-9 shows the backscatter image of sample $\mathrm{UO}_{2}-14\left(125^{\circ} \mathrm{C}\right.$ for 14 days). There appears to be a sort of roughness to the surface of the sample (perhaps due to relief polishing of alternating hard and soft phases). Figure B-10 shows sample $\mathrm{UO}_{2}-15\left(125^{\circ} \mathrm{C}\right.$ for 28 days) in backscatter mode. There appears to be the emergence of a second phase that shows as darker gray spots. This trend continues in samples $\mathrm{UO}_{2}-09\left(150^{\circ} \mathrm{C}\right.$ for 14 days) and $\mathrm{UO}_{2}-08\left(150^{\circ} \mathrm{C}\right.$ for 28 days) as shown in Figures B-11 and B-12.

Figures $\mathrm{B}-13$ and $\mathrm{B}-14$ show sample $\mathrm{UO}_{2}-03\left(250^{\circ} \mathrm{C}\right.$ for 14 days $)$ in regular emission mode. At low magnification (30X), Figure B-13 shows that the cement has broken away from the $\mathrm{UO}_{2}$ aggregate. A small piece of cement was retained in the plastic but drifted to the bottom right of Figure B-13. The surface of the aggregate was quite rough and, as shown in Figure B-14, there is a highly fractured area at the surface. Figure B-15 shows this fractured layer at $1,000 \mathrm{X}$ magnification where the numbered spots are where EDS analysis was conducted. Figures B-16 and B-17 show the backscatter image of this fractured zone. There was no evidence of calcium compounds (also not identified with the EDS), and the second phase areas found in the 125 and $150^{\circ} \mathrm{C}$ samples were not found. Figure B-18 (normal mode) shows the interior area of the $250^{\circ} \mathrm{C}$ sample where EDS analysis was performed. This interior area was solid with no evidence of degradation.

Figure B-19 shows sample $\mathrm{U}_{3} \mathrm{O}_{8}-01\left(250^{\circ} \mathrm{C}\right.$ for 14 days) with the $\mathrm{U}_{3} \mathrm{O}_{8}$ at the top of the photograph. Figure B-20 shows the edge of the $\mathrm{U}_{3} \mathrm{O}_{8}$ appears to be flaking and highly fractured. Many small crystals of urania have floated into the plastic mounting medium. A 2,000X magnification of the edge (Figure B-21) in regular and backscatter mode shows widespread intergranular fracturing. This fracturing is not evident in the center of the $\mathrm{U}_{3} \mathrm{O}_{8}$ aggregate as shown in Figure B-22. However, there is a duplex grain structure of large and small grains as shown in Figure B-23. As the numbers indicate, the large and small grained areas were analyzed (using EDS) separately for oxygen content. 
The results of the EDS analysis are given in Table B-3 for the $\mathrm{UO}_{2}$ samples and Table B-4 for the $\mathrm{U}_{3} \mathrm{O}_{8}$ samples. The "Standard" $\mathrm{UO}_{2}$ and $\mathrm{U}_{3} \mathrm{O}_{8}$ samples were unexposed to the hightemperature tests.

Table B-3. EDS analysis of $\mathrm{UO}_{2}$ DUCRETE.

\begin{tabular}{|c|c|c|c|c|c|c|c|}
\hline Sample ID & $\begin{array}{c}\text { Temperature } \\
\left({ }^{\circ} \mathrm{C}\right)\end{array}$ & $\begin{array}{c}\text { Time } \\
\text { (days) }\end{array}$ & $\begin{array}{l}\text { Oxygen } \\
\text { (wt\%) }\end{array}$ & $\begin{array}{l}\text { Sigma } \\
(w t \%)\end{array}$ & $\begin{array}{l}\text { Uranium } \\
\text { (wt\%) }\end{array}$ & $\begin{array}{l}\mathrm{O} / \mathrm{U} \text { mole } \\
\text { ratio }\end{array}$ & $\begin{array}{l}\text { Edge or } \\
\text { center }\end{array}$ \\
\hline $\begin{array}{l}\text { Standard } \\
\mathrm{UO}_{2}\end{array}$ & None & None & 12.31 & 2.74 & 87.69 & 2.09 & Edge \\
\hline $\begin{array}{l}\text { Standard } \\
\mathrm{UO}_{2}\end{array}$ & None & None & 11.56 & 0.59 & 88.44 & 1.94 & Center \\
\hline $\mathrm{UO}_{2}-11$ & 90 & 14 & 13.88 & 3.95 & 86.12 & 2.40 & Edge \\
\hline $\mathrm{UO}_{2-11}$ & 90 & 14 & 12.60 & 0.27 & 87.40 & 2.14 & Center \\
\hline $\mathrm{UO}_{2}-12$ & 90 & 14 & 11.41 & 2.20 & 88.59 & 1.92 & Edge \\
\hline $\mathrm{UO}_{2}-12$ & 90 & 14 & 12.06 & 0.29 & 87.94 & 2.04 & Center \\
\hline $\mathrm{UO}_{2}-06$ & 90 & 28 & 12.61 & 2.10 & 87.39 & 2.15 & Edge \\
\hline $\mathrm{UO}_{2}-06$ & 90 & 28 & 11.32 & 0.48 & 88.68 & -1.90 & Center \\
\hline $\mathrm{UO}_{2}-07$ & 90 & 28 & 8.52 & 1.06 & 91.48 & 1.39 & Edge \\
\hline $\mathrm{UO}_{2}-07$ & 90 & 28 & 11.08 & 0.23 & 88.92 & 1.85 & Center \\
\hline $\mathrm{UO}_{2}-13$ & 125 & 14 & 14.01 & 1.43 & 85.99 & 2.42 & Edge \\
\hline $\mathrm{UO}_{2}-13$ & 125 & 14 & 12.20 & 0.17 & 87.80 & 2.07 & Center \\
\hline $\mathrm{UO}_{2}-14$ & 125 & 14 & 15.98 & 1.55 & 84.02 & 2.83 & Edge \\
\hline $\mathrm{UO}_{2}-14$ & 125 & 14 & 10.51 & 0.57 & 89.49 & 1.75 & Center \\
\hline $\begin{array}{l}\mathrm{UO}_{2}-15 \\
\text { Dark } \\
\text { Feature }\end{array}$ & 125 & 14 & 15.04 & 4.62 & 28.92 & 7.74 & Edge \\
\hline $\mathrm{UO}_{2}-15$ & 125 & 28 & 10.99 & 0.34 & 89.01 & 1.84 & Center \\
\hline $\mathrm{UO}_{2}-16$ & 125 & 28 & 14.08 & 4.47 & 85.92 & 2.44 & Edge \\
\hline $\mathrm{UO}_{2}-16$ & 125 & 28 & 12.28 & 0.57 & 87.72 & 2.08 & Center \\
\hline $\mathrm{UO}_{2}-09$ & 150 & 14 & 9.99 & 1.28 & 30.45 & 4.88 & Edge \\
\hline $\mathrm{UO}_{2}-09$ & 150 & 14 & 11.23 & 0.33 & 88.77 & 1.88 & Center \\
\hline
\end{tabular}


Table B-3. (continued).

\begin{tabular}{|c|c|c|c|c|c|c|c|}
\hline Sample ID & $\begin{array}{c}\text { Temperature } \\
\left({ }^{\circ} \mathrm{C}\right)\end{array}$ & $\begin{array}{l}\text { Time } \\
\text { (days) }\end{array}$ & $\begin{array}{l}\text { Oxygen } \\
\text { (wt\%) }\end{array}$ & $\begin{array}{l}\text { Sigma } \\
\text { (wt\%) }\end{array}$ & $\begin{array}{l}\text { Uranium } \\
\text { (wt\%) }\end{array}$ & $\begin{array}{c}\mathrm{O} / \mathrm{U} \text { mole } \\
\text { ratio }\end{array}$ & $\begin{array}{l}\text { Edge or } \\
\text { center }\end{array}$ \\
\hline $\mathrm{UO}_{2}-10$ & 150 & 14 & 16.15 & 0.42 & 83.85 & 2.87 & Edge \\
\hline $\mathrm{UO}_{2}-10$ & 150 & 14 & 10.24 & 0.28 & 89.76 & 1.70 & Center \\
\hline $\mathrm{UO}_{2}-05$ & 150 & 28 & 17.59 & 2.29 & 82.41 & 3.17 & Edge \\
\hline $\mathrm{UO}_{2^{-0}}$ & 150 & 28 & 11.35 & 0.50 & 88.65 & 1.90 & Center \\
\hline $\mathrm{UO}_{2}-08$ & 150 & 28 & 11.73 & 4.99 & 88.27 & 1.98 & Edge \\
\hline $\mathrm{UO}_{2}-08$ & 150 & 28 & 10.46 & $0.93 \dot{4}$ & 89.54 & 1.78 & Center \\
\hline $\mathrm{UO}_{2}-04$ & 150 & 28 & 12.35 & 5.59 & 87.65 & 2.10 & Edge \\
\hline $\mathrm{UO}_{2^{-04}}$ & 150 & 28 & 9.97 & 0.39 & 90.03 & 1.65 & Center \\
\hline $\mathrm{UO}_{2}-03$ & 250 & 14 & 12.08 & 1.16 & 87.92 & 2.04 & Edge \\
\hline $\mathrm{UO}_{2}-03$ & 250 & 14 & 11.46 & 0.60 & 88.54 & 1.93 & Center \\
\hline
\end{tabular}


Table B-4. EDS analysis of $\mathrm{U}_{3} \mathrm{O}_{8}$ DUCRETE.

\begin{tabular}{|c|c|c|c|c|c|c|c|}
\hline Sample ID & $\begin{array}{c}\text { Temperature } \\
\left({ }^{\circ} \mathrm{C}\right) \\
\end{array}$ & $\begin{array}{c}\text { Time } \\
\text { (days) }\end{array}$ & $\begin{array}{l}\text { Oxygen } \\
(w t \%)\end{array}$ & $\begin{array}{l}\text { Sigma } \\
(w t \%)\end{array}$ & $\begin{array}{c}\text { Uranium } \\
\text { (wt\%) }\end{array}$ & $\begin{array}{c}\mathrm{O} / \mathrm{U} \text { mole } \\
\text { ratio }\end{array}$ & $\begin{array}{c}\text { Edge or } \\
\text { center }\end{array}$ \\
\hline $\begin{array}{l}\text { Standard } \\
\mathrm{U}_{3} \mathrm{O}_{8} \text { small } \\
\text { grains }\end{array}$ & None & None & 15.94 & 4.73 & 84.06 & 2.82 & Edge \\
\hline $\begin{array}{l}\text { Standard } \\
\mathrm{U}_{3} \mathrm{O}_{8} \\
\text { large grains }\end{array}$ & None & None & 14.41 & 0.29 & 85.59 & 2.50 & Edge \\
\hline $\begin{array}{l}\text { Standard } \\
\mathrm{U}_{3} \mathrm{O}_{8} \\
\text { small grains }\end{array}$ & None & None & 16.37 & 8.90 & 83.63 & 2.91 & Center \\
\hline $\begin{array}{l}\text { Standard } \\
\mathrm{U}_{3} \mathrm{O}_{8} \\
\text { large grains }\end{array}$ & None & None & 16.39 & 0.25 & 83.61 & 2.92 & Center \\
\hline $\begin{array}{l}\mathrm{U}_{3} \mathrm{O}_{8}-02 \\
\text { small grains }\end{array}$ & 250 & 14 & 22.46 & 0.84 & 77.54 & 4.31 & Edge \\
\hline $\begin{array}{l}\mathrm{U}_{3} \mathrm{O}_{8}-02 \\
\text { large grains }\end{array}$ & 250 & 14 & 19.61 & 1.49 & 80.39 & 3.63 & Edge \\
\hline $\begin{array}{l}\mathrm{U}_{3} \mathrm{O}_{8}-02 \\
\text { small grains }\end{array}$ & 250 & 14 & 21.49 & 1.54 & 78.51 & 4.07 & Center \\
\hline $\begin{array}{l}\mathrm{U}_{3} \mathrm{O}_{8}-02 \\
\text { large grains }\end{array}$ & 250 & 14 & 15.81 & 0.19 & 84.19 & 2.80 & Center \\
\hline $\begin{array}{l}\mathrm{U}_{3} \mathrm{O}_{8}-01 \\
\text { small grains }\end{array}$ & 250 & 14 & 22.60 & 2.94 & 77.40 & 4.34 & Edge \\
\hline $\begin{array}{l}\mathrm{U}_{3} \mathrm{O}_{8}-01 \\
\text { large grains }\end{array}$ & 250 & 14 & 16.93 & 0.81 & 83.07 & 3.03 & Edge \\
\hline $\begin{array}{l}\mathrm{U}_{3} \mathrm{O}_{8}-01 \\
\text { small grains }\end{array}$ & 250 & 14 & 25.53 & 1.13 & 74.67 & 5.09 & Center \\
\hline $\begin{array}{l}\mathrm{U}_{3} \mathrm{O}_{8}-01 \\
\text { large grains }\end{array}$ & 250 & 14 & 18.74 & 3.54 & 81.26 & 3.43 & Center \\
\hline
\end{tabular}


Table B-5 shows the physical changes in the in $\mathrm{UO}_{2}$ aggregate, and Table B-6 shows the physical changes in the $\mathrm{U}_{3} \mathrm{O}_{8}$ aggregate.

Table B-5. Physical changes in $\mathrm{UO}_{2}$ aggregate.

\begin{tabular}{ccccccc}
\hline $\begin{array}{c}\text { Temperature } \\
\left({ }^{\circ} \mathrm{C}\right)\end{array}$ & $\begin{array}{c}\text { Time } \\
\text { (days) }\end{array}$ & $\begin{array}{c}\text { Diameter } \\
\text { change } \\
\text { (in.) }\end{array}$ & $\begin{array}{c}\text { Length } \\
\text { change } \\
\text { (in.) }\end{array}$ & $\begin{array}{c}\text { Weight } \\
\text { change } \\
(\mathrm{g})\end{array}$ & $\begin{array}{c}\text { Volume } \\
\text { change } \\
(\text { in. })^{3}\end{array}$ & $\begin{array}{c}\text { Density } \\
\text { change } \\
\left(\mathrm{g} / \mathrm{cm}^{3}\right)\end{array}$ \\
\hline 90 & 7 & 0.0000 & 0.0000 & 0.0 & 0.000 & 0.0. \\
90 & 14 & -0.0001 & -0.0001 & 0.1 & -0.001 & 0.2 \\
90 & 28 & & & & & \\
150 & 7 & 0.0000 & 0.0000 & 0.0 & 0.000 & -0.0 \\
150 & 14 & -0.0002 & -0.0002 & 0.0 & -0.001 & 0.0 \\
150 & 28 & & & & & \\
250 & 7 & 0.0001 & 0.0000 & 0.0 & 0.000 & 0.0 \\
250 & 14 & -0.0006 & -0.0012 & 0.1 & -0.003 & 0.3 \\
250 & 28 & & & & & \\
\hline
\end{tabular}

Table B-6. Physical changes in $\mathrm{U}_{3} \mathrm{O}_{8}$ aggregate.

\begin{tabular}{ccccc}
$\begin{array}{c}\text { Temperature } \\
\left({ }^{\circ} \mathrm{C}\right)\end{array}$ & $\begin{array}{c}\text { Time } \\
(\text { days })\end{array}$ & $\begin{array}{c}\text { Thickness change } \\
(\text { in. })\end{array}$ & $\begin{array}{c}\text { Weight change } \\
(\mathrm{g})\end{array}$ & $\begin{array}{c}\text { Density change } \\
\left(\mathrm{g} / \mathrm{cm}^{3}\right)\end{array}$ \\
\hline 90 & 7 & 0.0007 & 0.1 & 0.0 \\
90 & 14 & 0.0000 & -0.1 & 0.0 \\
90 & 28 & & & \\
150 & 7 & 0.0009 & 0.0 & 0.0 \\
150 & 14 & -0.0005 & 0.0 & 0.0 \\
150 & 28 & & & \\
250 & 7 & Disintegrated & 0.0 & Disintegrated \\
250 & 14 & -0.0001 & 0.1 & 0.1 \\
250 & 28 & & & \\
\hline
\end{tabular}




\section{DISCUSSION OF RESULTS}

The SEM photographs (normal secondary emission mode and backscatter mode) give strong indications of changes at the surface of the $\mathrm{UO}_{2}$ aggregate starting at $125^{\circ} \mathrm{C}$ and exposures of 28 days. This change appears to be the slow emergence of a second phase within the urania (see Figure B-10). At the highest temperature $\left(250^{\circ} \mathrm{C}\right)$, there is a fracturing at the surface of the $\mathrm{UO}_{2}$, but the secondary phase was not observed. Since the cement spalled away from the $\mathrm{UO}_{2}$ aggregate at $250^{\circ} \mathrm{C}$, we did not analyze for $\mathrm{UO}_{2}$ residue on the cement side of the interface. It is possible that there might be evidence of a chemical reaction in that region. There was no. evidence of a chemical reaction with cement constituents $\left(\mathrm{Ca}, \mathrm{Si}\right.$, etc.) on the $\mathrm{UO}_{2}$ side of the interface. The crumbling of the $\mathrm{UO}_{2}$ surface certainly would effectively severe the bond with the cement and greatly weaken the DUCRETE. The SEM photographs of the $\mathrm{U}_{3} \mathrm{O}_{8}$ aggregate exposed to $250^{\circ} \mathrm{C}$ for 14 days showed the surface to be highly fractured and flaking.

The EDS analysis is best evaluated by considering the $\mathrm{O} / \mathrm{U}$ molar ratio numbers. For $\mathrm{UO}_{2}$, the theoretical $\mathrm{O} / \mathrm{U}$ ratio should be 2.00; for $\mathrm{U}_{3} \mathrm{O}_{8}$, the ratio should be 2.67; for $\mathrm{UO}_{3}$, the ratio should be 3.00. The "standard" unexposed $\mathrm{UO}_{2}$ aggregate had $0 / \mathrm{U}$ values very close to theoretical 2.00 (2.09 and 1.94) at the edge and in the center of the aggregate. At $90^{\circ} \mathrm{C}$, the values did not change appreciably. At $125^{\circ} \mathrm{C}$, the numbers have a lot of scatter but there appears to be a trend for oxygen pickup at the edge (with values of $2.42,2.83$, and 2.44 ). At $150^{\circ} \mathrm{C}$, this trend seems to continue with edge values of $4.88,2.87,3.27,1.98$, and 2.10 . The center $\mathrm{O} / \mathrm{U}$ ratios are somewhat less than $2.00(1.88,1.70,1.90,1.78,1.65)$. The variability of these numbers may be associated with the apparent emergence of a second phase noticed at the surface of the aggregate. The second phase probably has a different O/U value, and the EDS spot analysis would be dependent upon which phase the spot is analyzing.

It is of interest that the $\mathrm{O} / \mathrm{U}$ ratio is 2.04 at the edge of the $\mathrm{UO}_{2}$ aggregate exposed to $250^{\circ} \mathrm{C}$. No second phase was found in these samples. One possibility is that the high oxygen grains either spalled away or are still attached to the cement side of the interface.

The "standard" unexposed " $\mathrm{U}_{3} \mathrm{O}_{8}$ " aggregate had an $\mathrm{O} / \mathrm{U}$ ratio of 2.82 in the small grains at the edge and less oxygen $(\mathrm{O} / \mathrm{U}=2.50)$ in the large grains at the edge. There was no difference in the ratio for small or large grains in the interior (center) of the aggregate. However, the $\mathrm{O} / \mathrm{U}$ ratio of 2.92 was higher in oxygen than calculated for stoichiometric $\mathrm{U}_{3} \mathrm{O}_{8}(\mathrm{O} / \mathrm{U}=2.67)$, and the phase likely is $\mathrm{UO}_{3}$. After the high-temperature exposure, there was a big jump in oxygen values at the edge of the aggregate $(O / U=4.31,3.63,4.34,3.03)$ with small grains containing more oxygen than large grains (indication of a diffusional process). These $\mathrm{O} / \mathrm{U}$ ratios were, in most cases, higher than the theoretical value for $\mathrm{UO}_{3}$. This leads to a speculation that the $\mathrm{U}_{3} \mathrm{O}_{8}$ or $\mathrm{UO}_{3}$ might be forming hydroxyl molecules $\left(\mathrm{U}_{3} \mathrm{O}_{8} \mathrm{xH}_{2} \mathrm{O}\right.$ or $\left.\mathrm{UO}_{3} \times \mathrm{xH}_{2} \mathrm{O}\right)$. The center of the aggregate also had increased $\mathrm{O} / \mathrm{U}$ ratios $(4.07,2.80,5.09$, and 3.43$)$ with the largest values being in the small grains (indication of a diffusional process).

The results of the physical changes to "bare" aggregate are difficult to understand. The $\mathrm{UO}_{2}$ aggregate only gained a small amount of weight in two instances and did not expand but contracted slightly in three cases. The $\mathrm{U}_{3} \mathrm{O}_{8}$ expanded in two cases and contracted in two cases, gained a small amount of weight in two cases and lost weight in one case. However, one $\mathrm{U}_{3} \mathrm{O}_{8}$ aggregate piece disintegrated when exposed to $250^{\circ} \mathrm{C}$ (which indicated something is happening). 
A couple of explanations can be made: (a) The dimensional changes and weight changes take place at the surface and are small compared to the overall dimension or weight of the piece. However, one would have expected to see a change in the weight of the $\mathrm{U}_{3} \mathrm{O}_{8}$ pieces since the " $\mathrm{O} / \mathrm{U}$ ratio increased dramatically at the edge and in the center of the piece. (b) The lattice expansion at the surface does not cause much overall dimensional change because it is constrained by the rest of the piece. The outer layer contains a lot of strain that results in hoop stresses that are only relieved if the outer layer cracks and flakes away from the remainder of the piece.

A careful consideration of the weight change sheds some light on the situation. A cube of $\mathrm{U}_{3} \mathrm{O}_{8} 0.25 \mathrm{in}$. on a side occupies $0.256 \mathrm{~cm}^{3}$ volume and weighs $2.125 \mathrm{~g}$ and has $2.5237 \times 10^{-3}$ moles of $\mathrm{U}_{3} \mathrm{O}_{8}$. According to the reaction $\mathrm{U}_{3} \mathrm{O}_{8}+1 / 2 \mathrm{O}_{2} \rightarrow 3 \mathrm{UO}_{3}$, the expected weight gain would be $0.04 \mathrm{~g}$, which is at the level of sensitivity of the balance used. The problem is that most of the weight resides in the very heavy uranium atoms and we are adding fairly light oxygen atoms during any oxidation/reduction reactions. A much more sensitive balance would have to be used or a great number of aggregates should be used.

\section{CONCLUSIONS}

The surface of both the $\mathrm{UO}_{2}$ and $\mathrm{U}_{3} \mathrm{O}_{8}$ aggregate, contained in portland cement, severely cracked when exposed to moist air at $250^{\circ} \mathrm{C}$ for a time of 14 days.

No evidence was found for reaction of $\mathrm{UO}_{2}$ or $\mathrm{U}_{3} \mathrm{O}_{8}$ aggregate with chemicals (e.g., $\left.\mathrm{Ca}(\mathrm{OH})_{2}\right)$ found in portland cement. However, reaction products may be located within the cement side of the uranium oxide/cement interface and would be difficult to find. Also, small concentrations of calcium compounds may be found in the surface layer of uranium oxide that is cracking, and they are lost during the preparation process.

There was significant evidence found for diffusion of oxygen into the uranium oxide aggregate. This evidence was found both for $\mathrm{UO}_{2}$ and $\mathrm{U}_{3} \mathrm{O}_{8}$. The EDS technique yielded $\mathrm{O} / \mathrm{U}$ values that increased with exposure to moisture and air at elevated temperatures. The oxygen appears to diffuse into the aggregate because the $\mathrm{O} / \mathrm{U}$ values are higher at the surfaces (edge in cross-section) and in smaller grains. At the surface of the $\mathrm{UO}_{2}, \mathrm{O} / \mathrm{U}$ values indicate likely has converted to $\mathrm{UO}_{3}$ when exposed to $150^{\circ} \mathrm{C}$. There was evidence of formation of a second phase within the $\mathrm{UO}_{2}$ at the surface for temperatures between 125 and $250^{\circ} \mathrm{C}$. This phase may help explain variations in the $\mathrm{O} / \mathrm{U}$ values calculated from EDS data. The surface of the $\mathrm{UO}_{2}$ when exposed to $250^{\circ} \mathrm{C}$ has a $\mathrm{O} / \mathrm{U}$ value of about 2.00 . This puzzling result may be explained by a flaking away of the surface which was higher in oxygen content. The O/U values of the $\mathrm{U}_{3} \mathrm{O}_{8}$ when exposed to $250^{\circ} \mathrm{C}$ show it has gained sufficient oxygen at the surface and within the interior to have oxidized past $\mathrm{UO}_{3}$ to $\mathrm{UO}_{3} \times \mathrm{H}_{2} \mathrm{O}$.

Physical property measurements were inconclusive because the weight changes were on the same order of magnitude as the sensitivity of the balances and the dimensional changes are thought to take place in a small surface layer. Since one "bare" piece of $\mathrm{U}_{3} \mathrm{O}_{8}$ disintegrated after exposure to $250^{\circ} \mathrm{C}$, there is evidence of physical/chemical changes within the piece severe enough to cause stresses large enough to cause fracture throughout the body. 


\section{REFERENCES}

1. P.A. Lessing, "Development of 'DUCRETE'," INEL-94/0029, Idaho National Engineering Laboratory, Lockheed Martin Idaho Technologies, Idaho Falls, Idaho, 83415 (October 1994). 


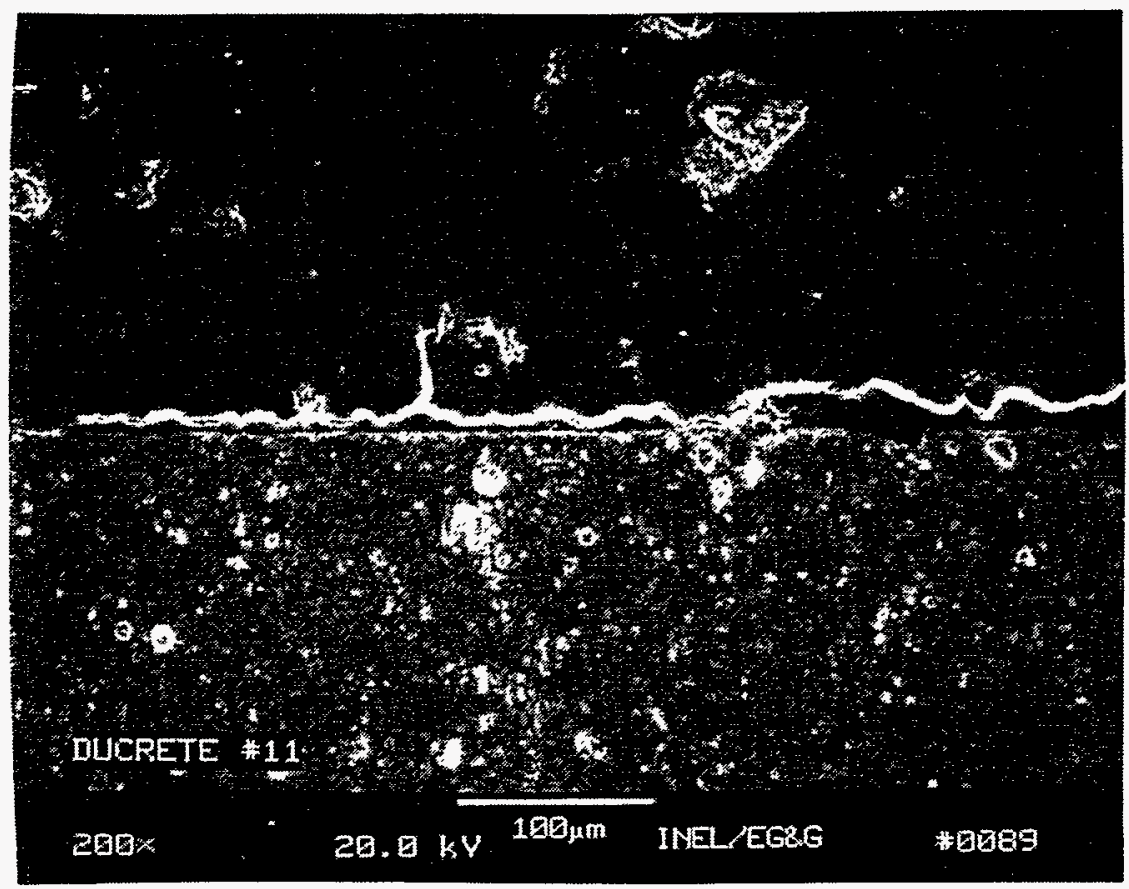

Figure B-1. Sample $\mathrm{UO}_{2}-11\left(90^{\circ} \mathrm{C}\right.$ for 14 days $)$ - SEM micrograph.

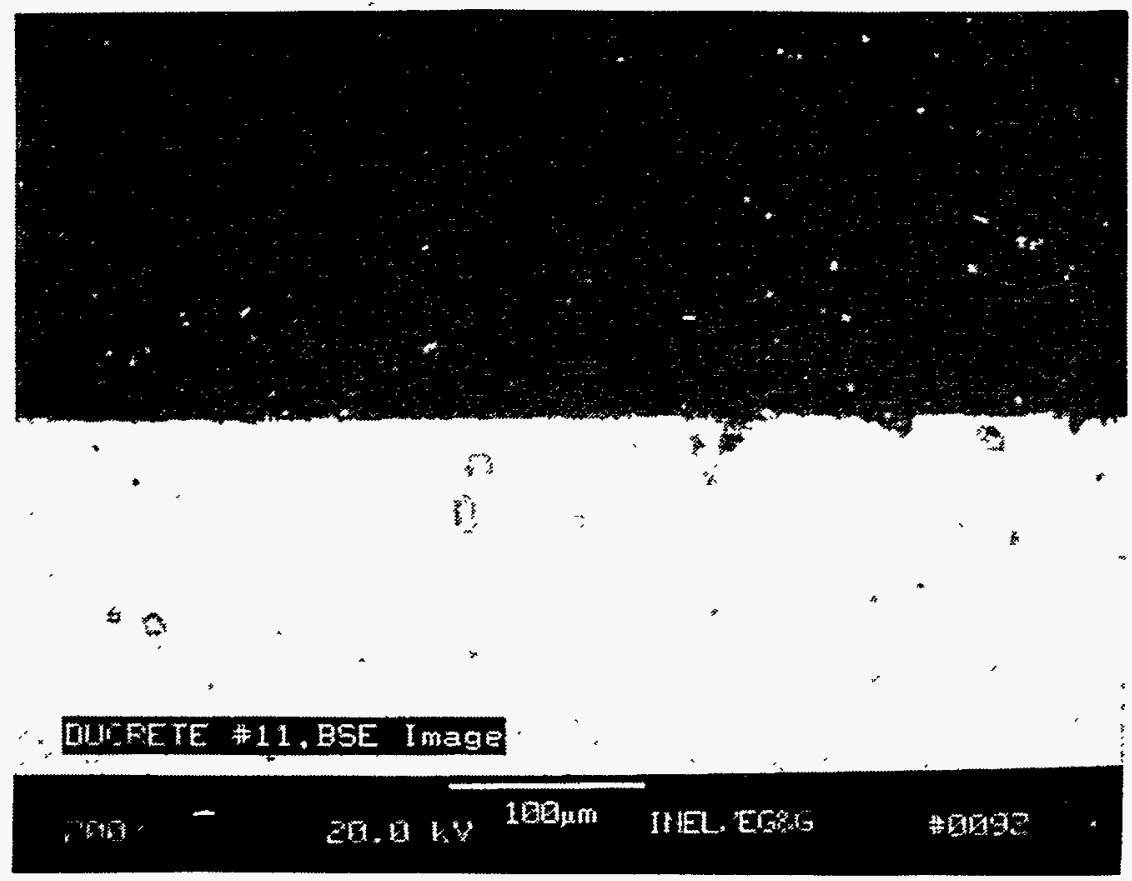

Figure B-2. Sample $\mathrm{UO}_{2}-11$ ( $90^{\circ} \mathrm{C}$ for 14 days) - SEM micrograph (backscatter mode). 


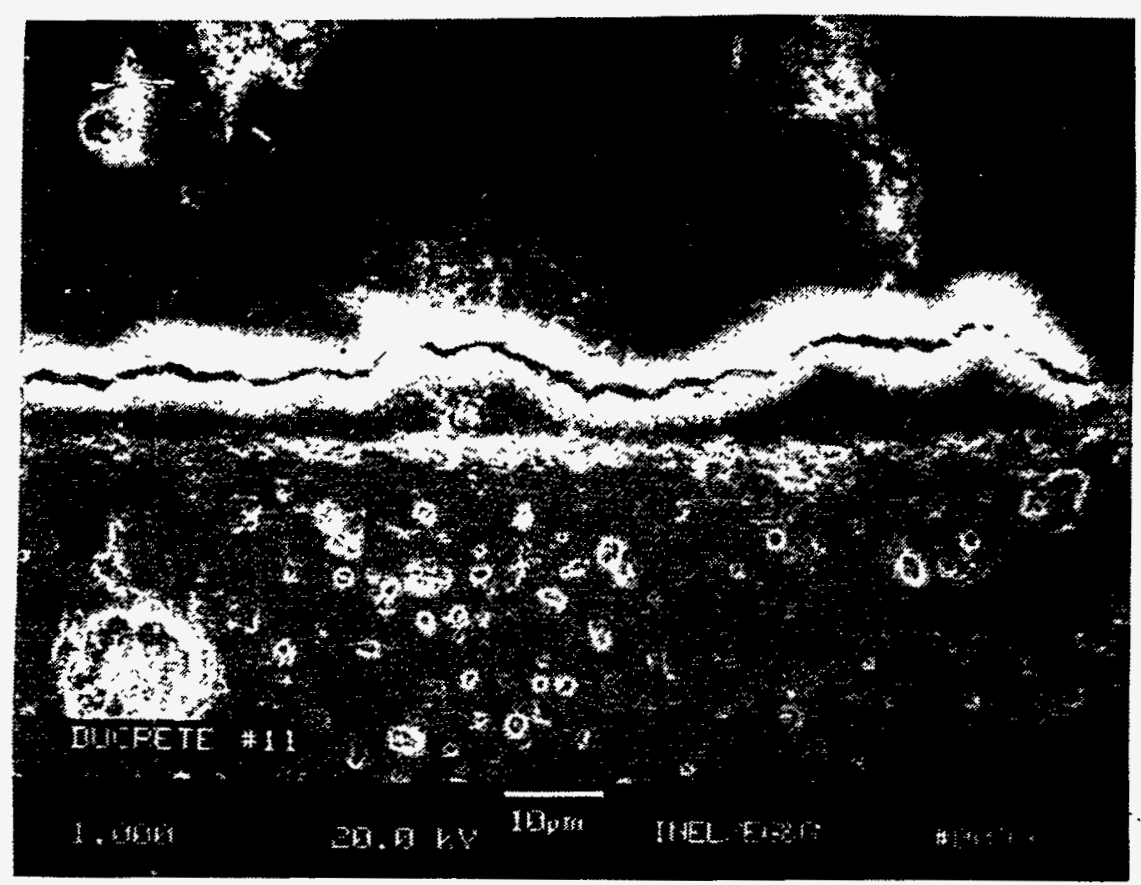

Figure B-3. Sample $\mathrm{UO}_{2}-11\left(90^{\circ} \mathrm{C}\right.$ for 14 days) - SEM micrograph; crack is in cement.

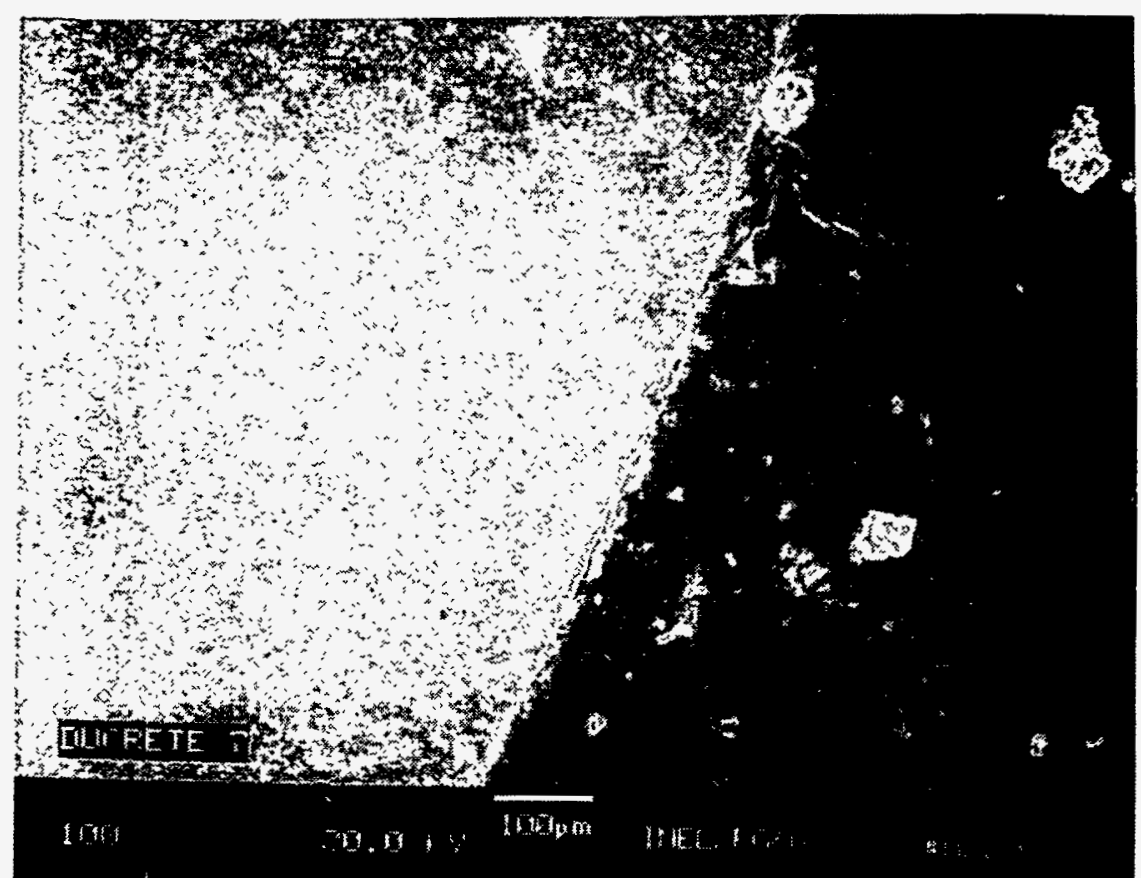

Figure B-4. Sample $\mathrm{UO}_{2}-07\left(90^{\circ} \mathrm{C}\right.$ for 28 days) - SEM micrograph; $\mathrm{UO}_{2}$ pellets is at left. 


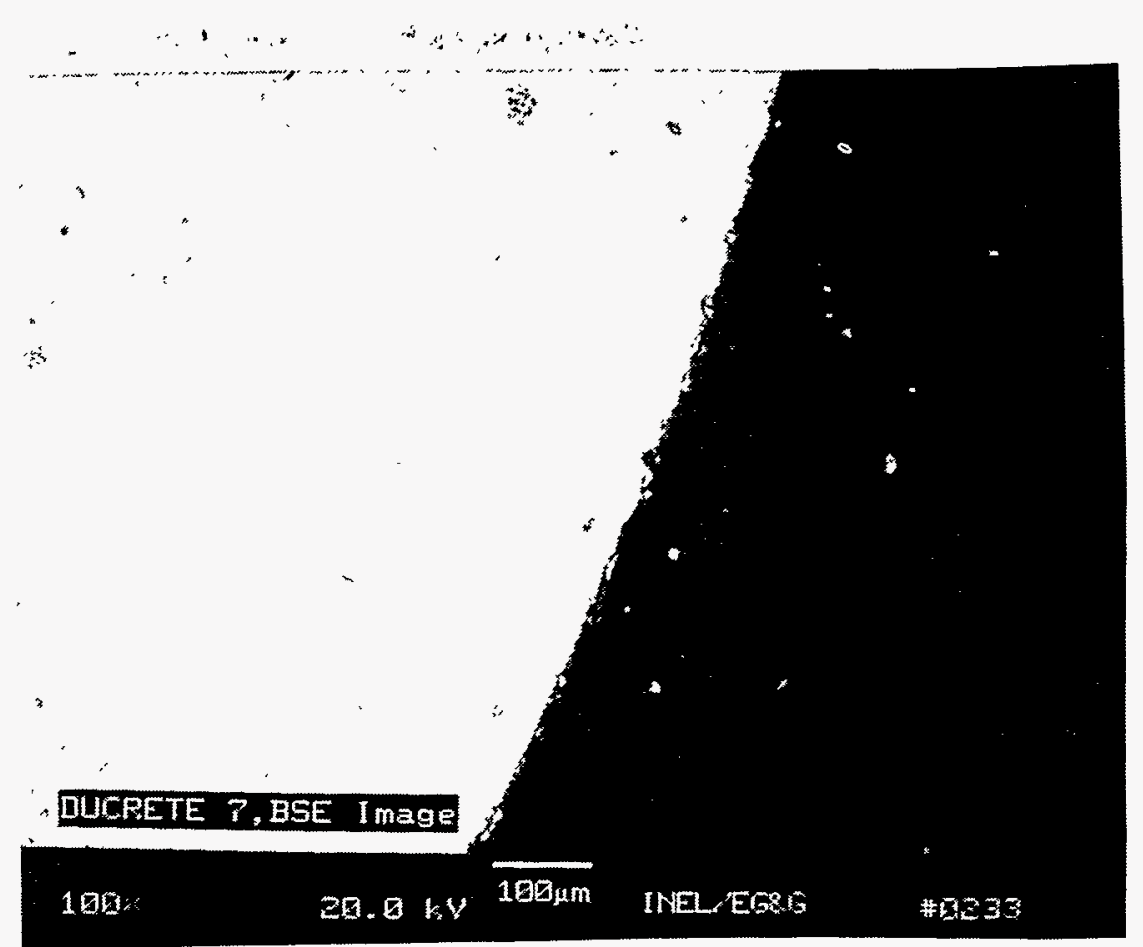

Figure B-5. Sample $\mathrm{UO}_{2}-07$ ( $90^{\circ} \mathrm{C}$ for 28 days) - SEM micrograph (backscatter mode).

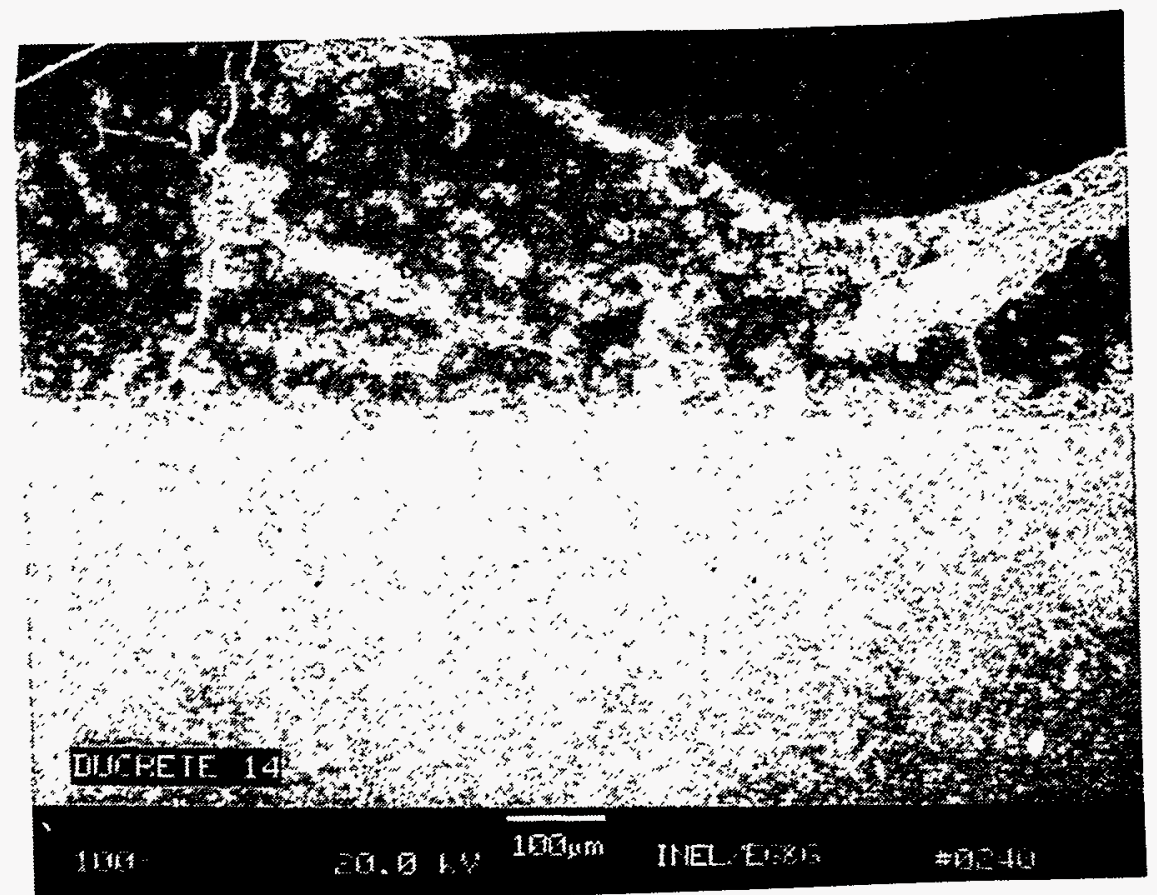

Figure B-6. Sample $\mathrm{UO}_{2}-14\left(125^{\circ} \mathrm{C}\right.$ for 14 days) - SEM micrograph. 


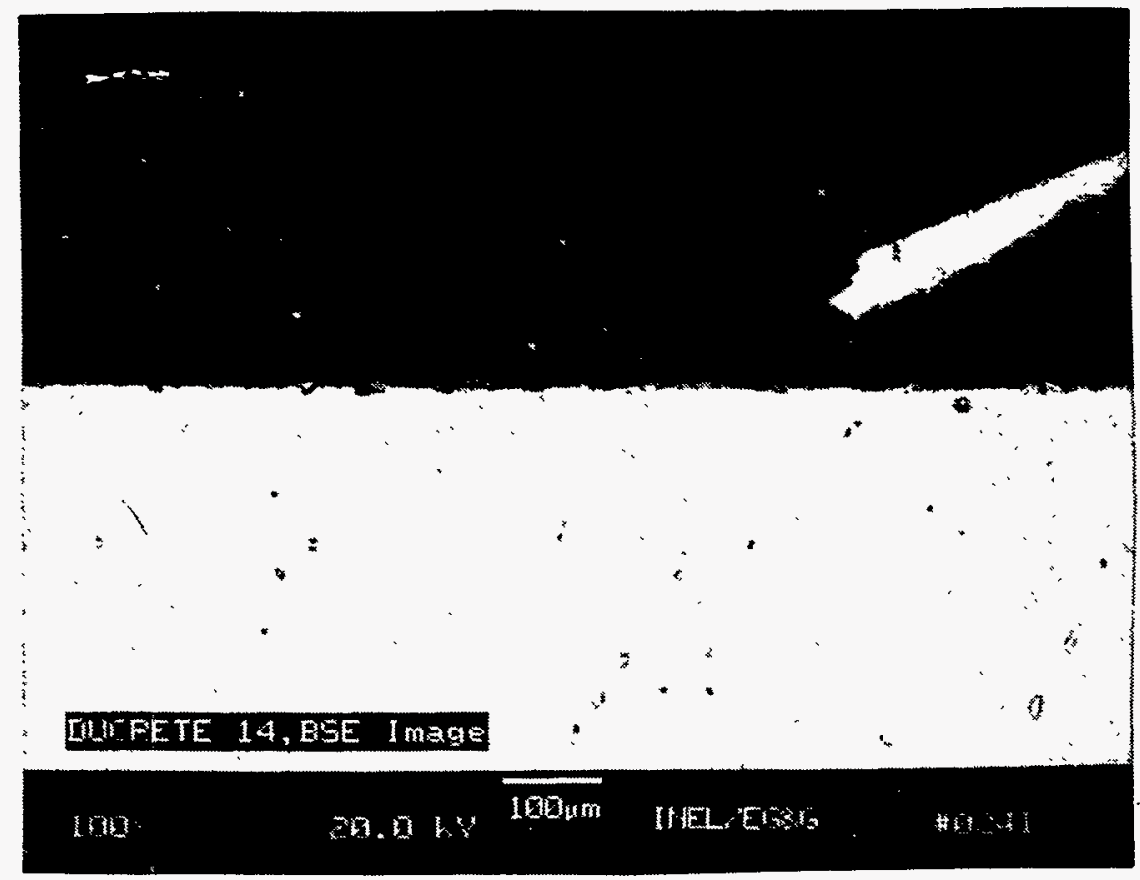

Figure B-7. Sample $\mathrm{UO}_{2}-14$ ( $125^{\circ} \mathrm{C}$ for 14 days) - SEM micrograph (backscatter mode).



Figure B-8. Sample $\mathrm{UO}_{2}-14\left(125^{\circ} \mathrm{C}\right.$ for 14 days) - SEM micrograph (backscatter mode), showing edge where EDS analysis was conducted. 


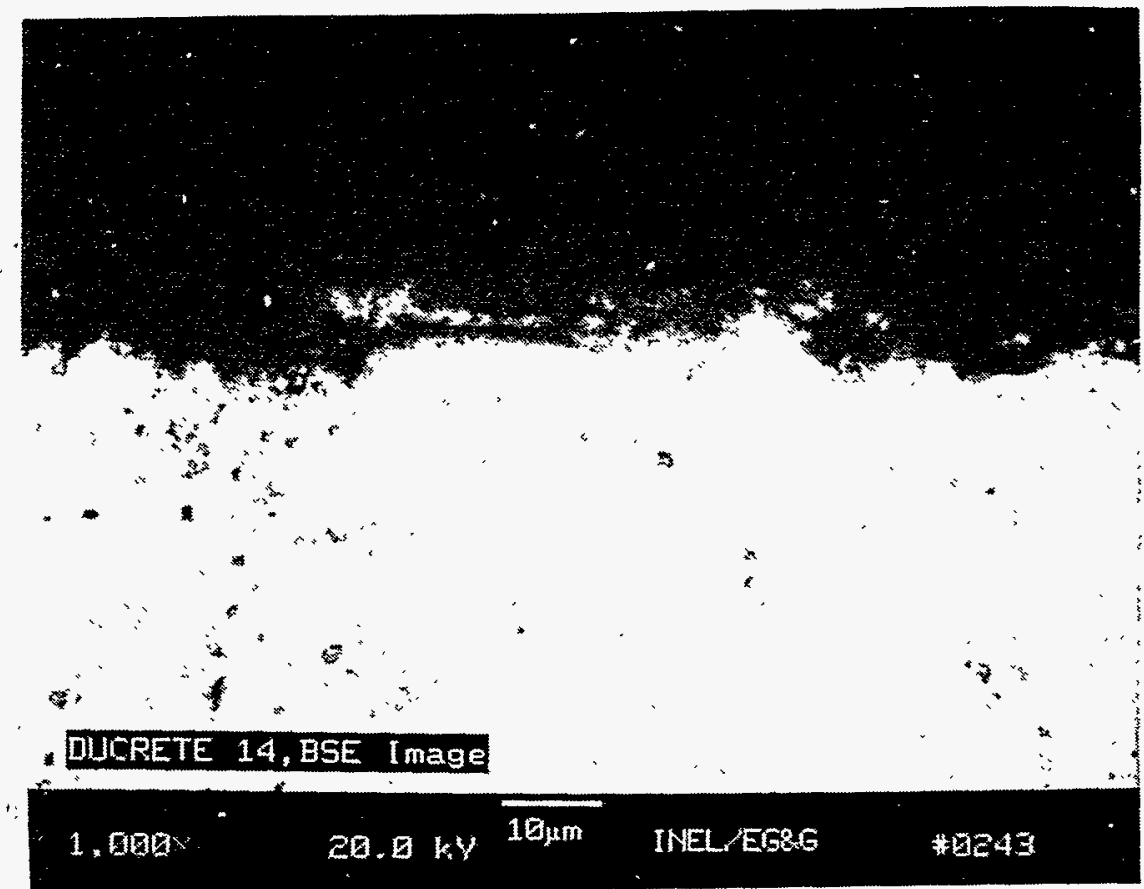

Figure B-9. Sample $\mathrm{UO}_{2}-14$ ( $125^{\circ} \mathrm{C}$ for 14 days) - SEM micrograph (backscatter mode); note roughness at the edge of $\mathrm{UO}_{2}$.

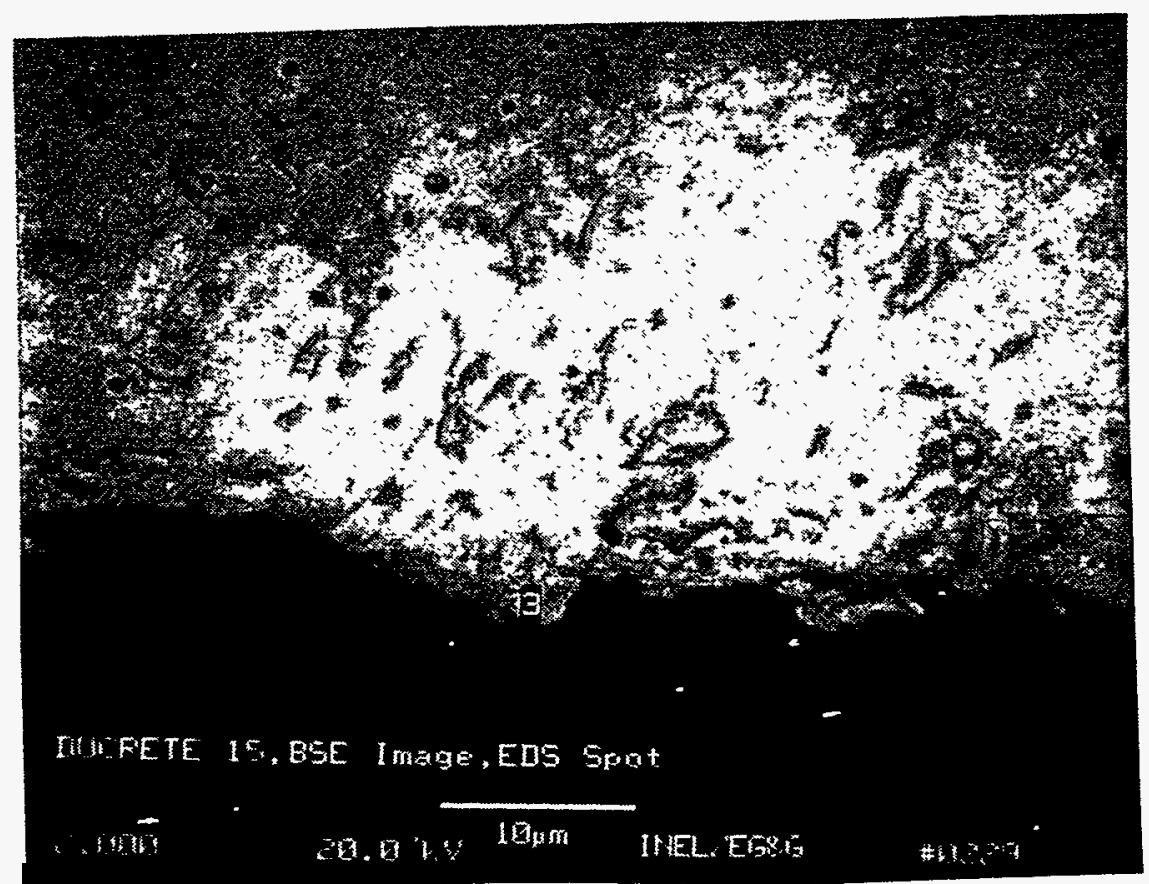

Figure B-10. Sample $\mathrm{UO}_{2}-15$ ( $125^{\circ} \mathrm{C}$ for 28 days) - SEM micrograph (backscatter mode); note gray areas due to compositional or hardness variations. 




Figure B-11. Sample $\mathrm{UO}_{2}-09\left(150^{\circ} \mathrm{C}\right.$ for 14 days) - SEM micrograph (backscatter mode).

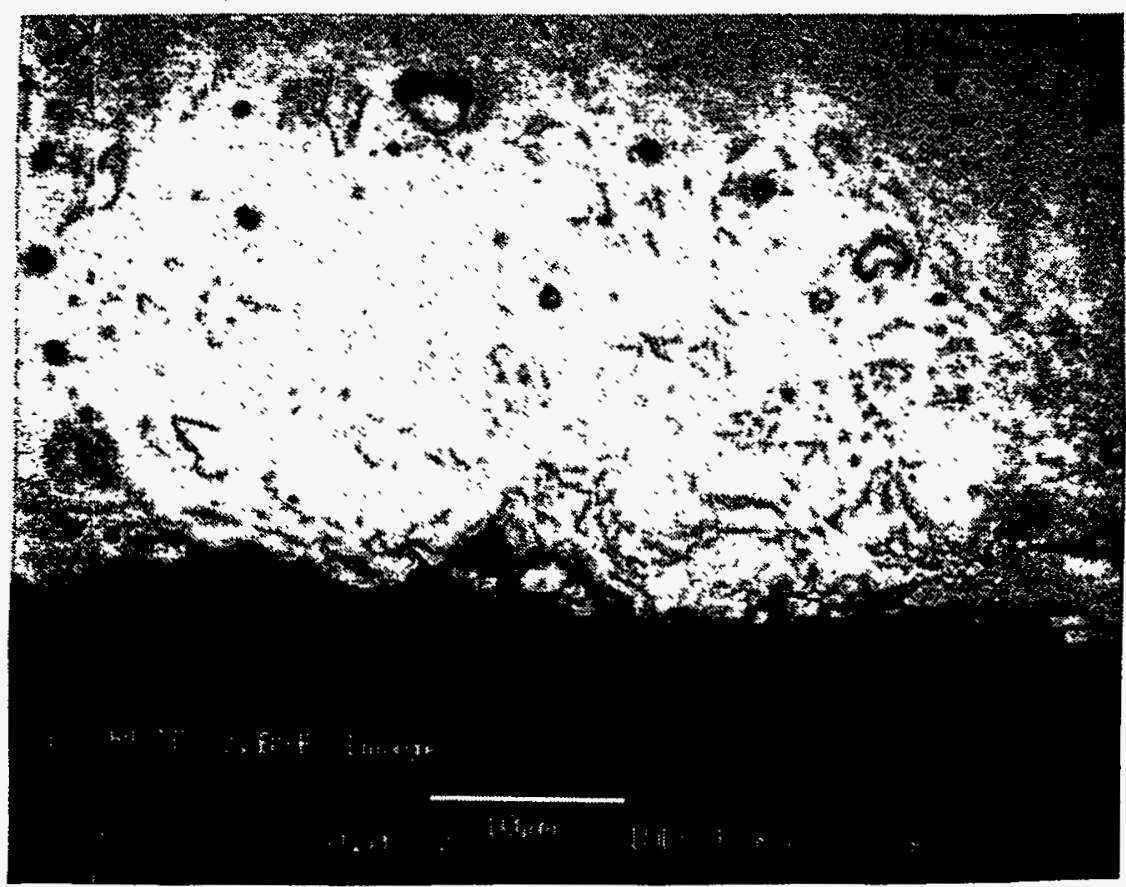

Figure B-12. Sample $\mathrm{UO}_{2}-08\left(150^{\circ} \mathrm{C}\right.$ for 28 days) - SEM micrograph (backscatter mode). 




Figure B-13. Sample $\mathrm{UO}_{2}-03\left(250^{\circ} \mathrm{C}\right.$ for 14 days $)$ - SEM micrograph.

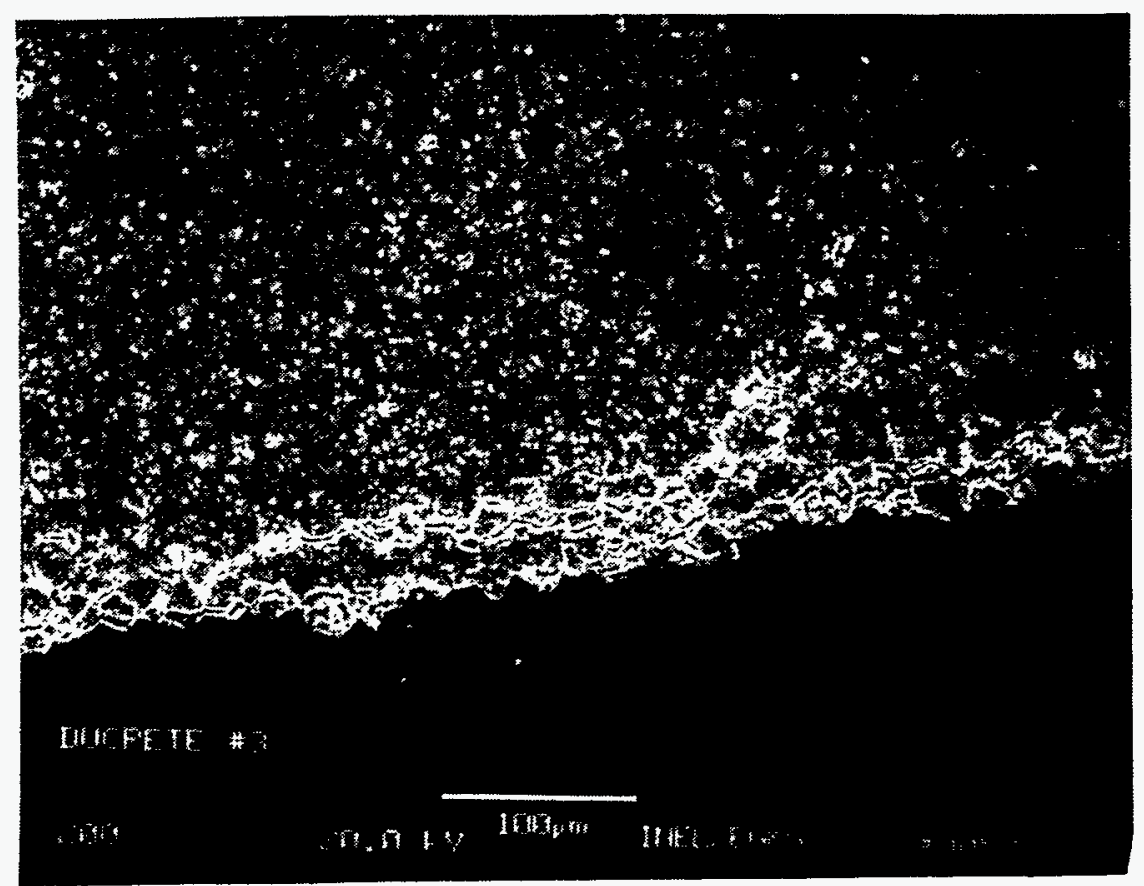

Figure B-14. Sample $\mathrm{UO}_{2}-03\left(250^{\circ} \mathrm{C}\right.$ for 14 days $)$ - SEM micrograph at $200 \mathrm{X}$ magnification. 


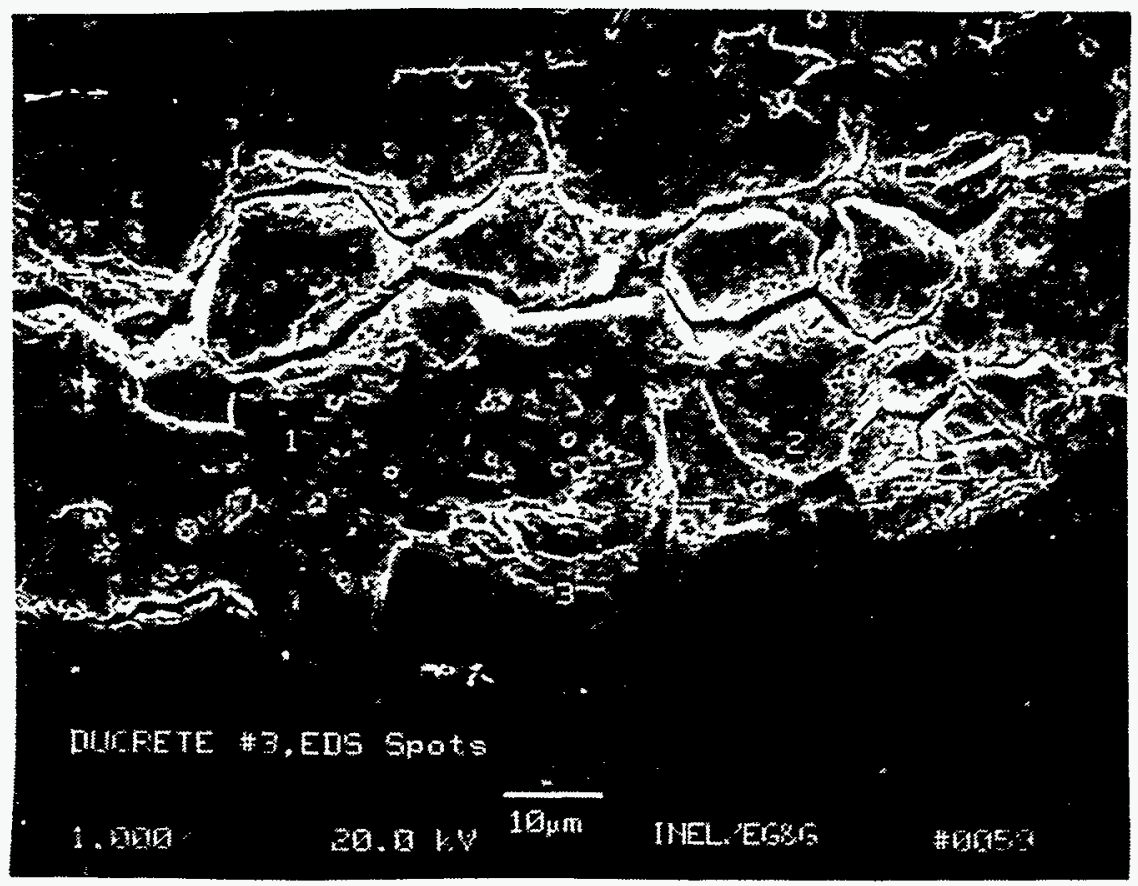

Figure B-15. Sample $\mathrm{UO}_{2}-03\left(250^{\circ} \mathrm{C}\right.$ for 14 days $)$ - SEM micrograph at $1000 \mathrm{X}$ magnification.

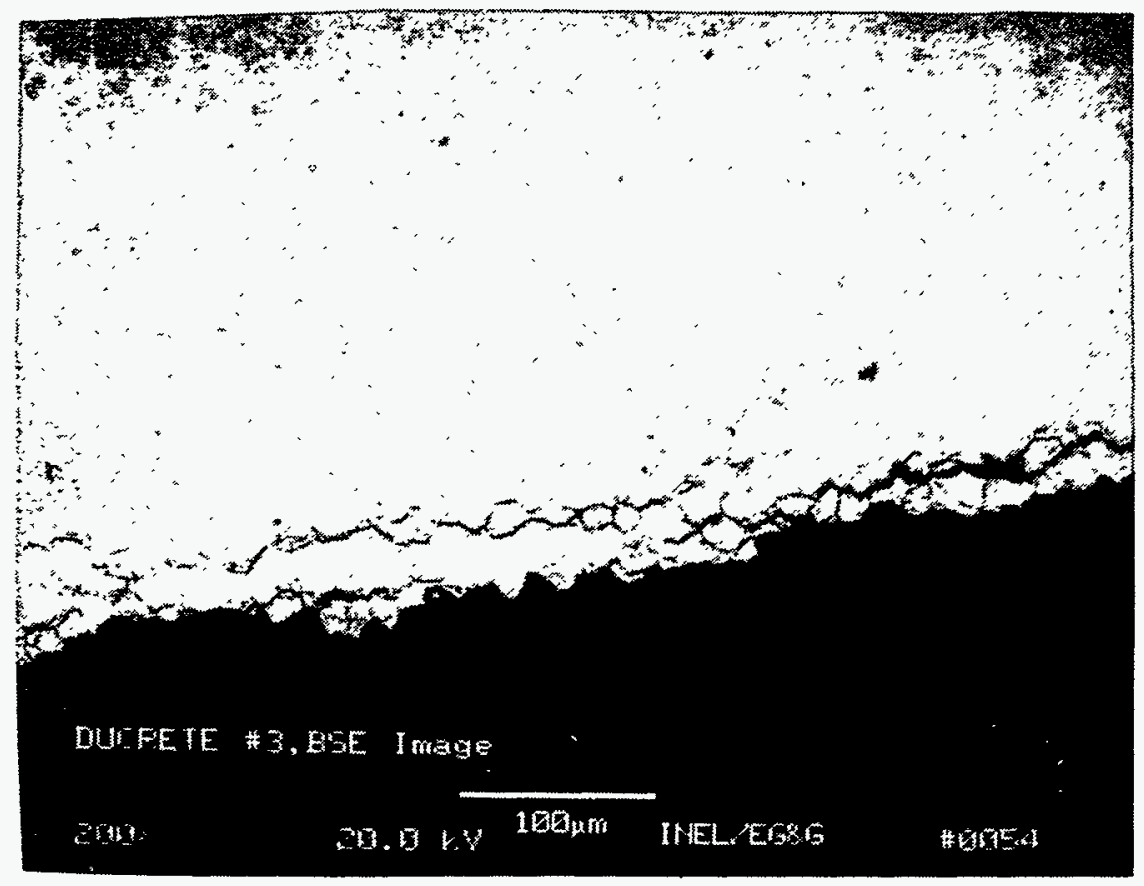

Figure B-16. Sample $\mathrm{UO}_{2}-03$ ( $250^{\circ} \mathrm{C}$ for 14 days) - SEM micrograph (backscatter mode). 


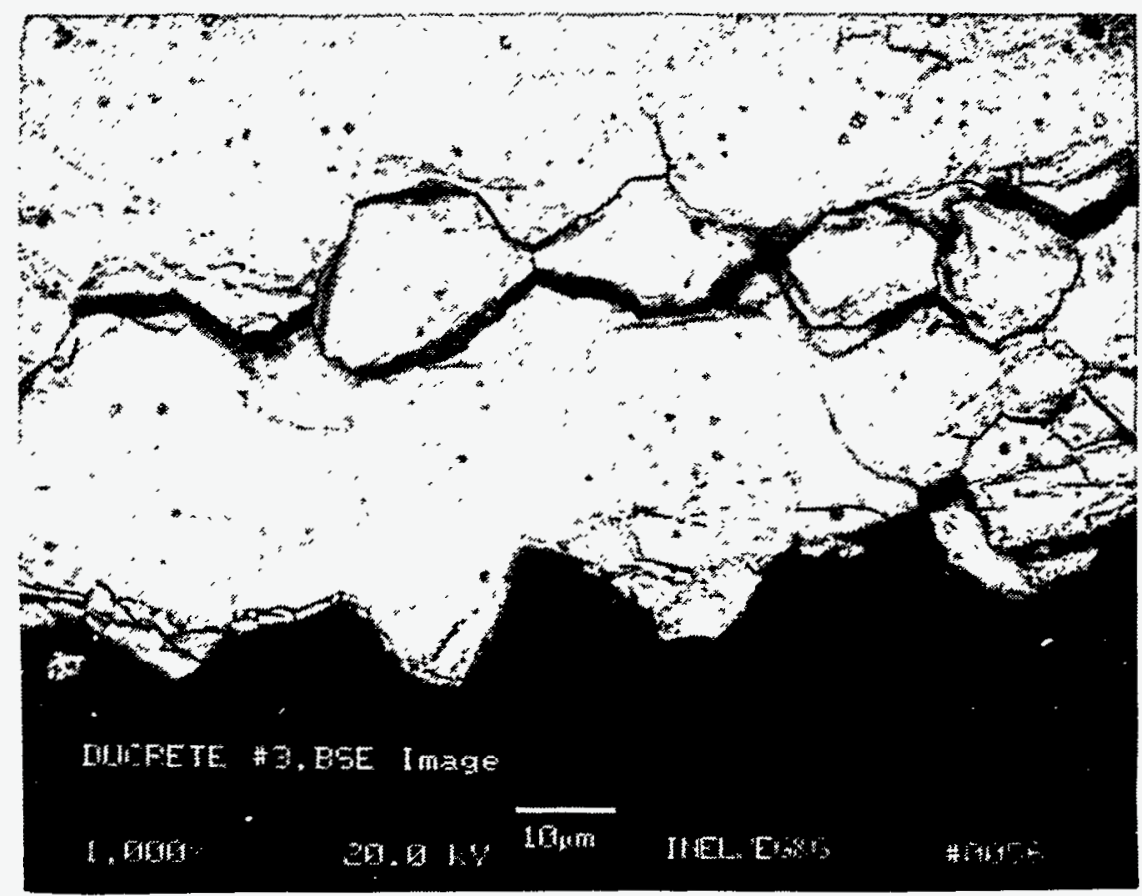

Figure B-17. Sample $\mathrm{UO}_{2}-03\left(250^{\circ} \mathrm{C}\right.$ for 14 days) - SEM micrograph (backscatter mode) at $1000 \mathrm{X}$ magnification.

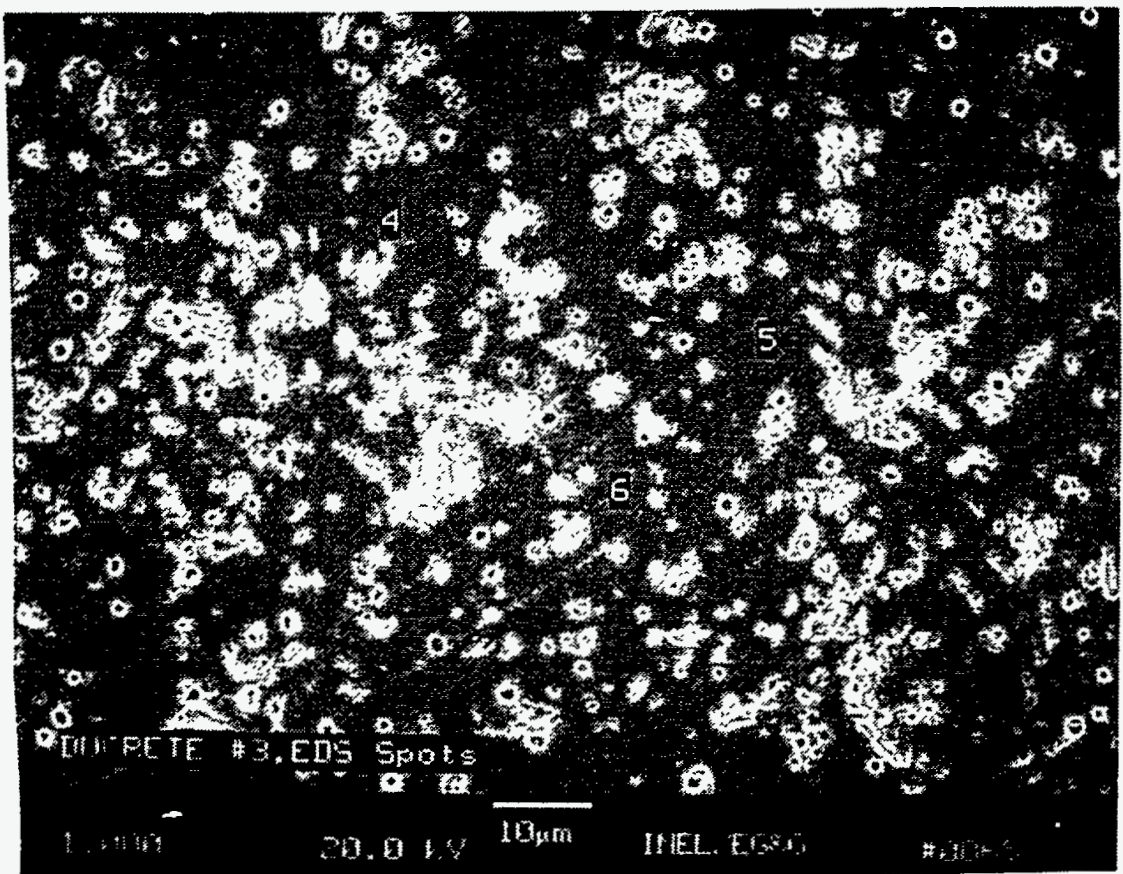

Figure B-18. Sample $\mathrm{UO}_{2}-03\left(250^{\circ} \mathrm{C}\right.$ for 14 days $)$ - SEM micrograph of interior of sample. 


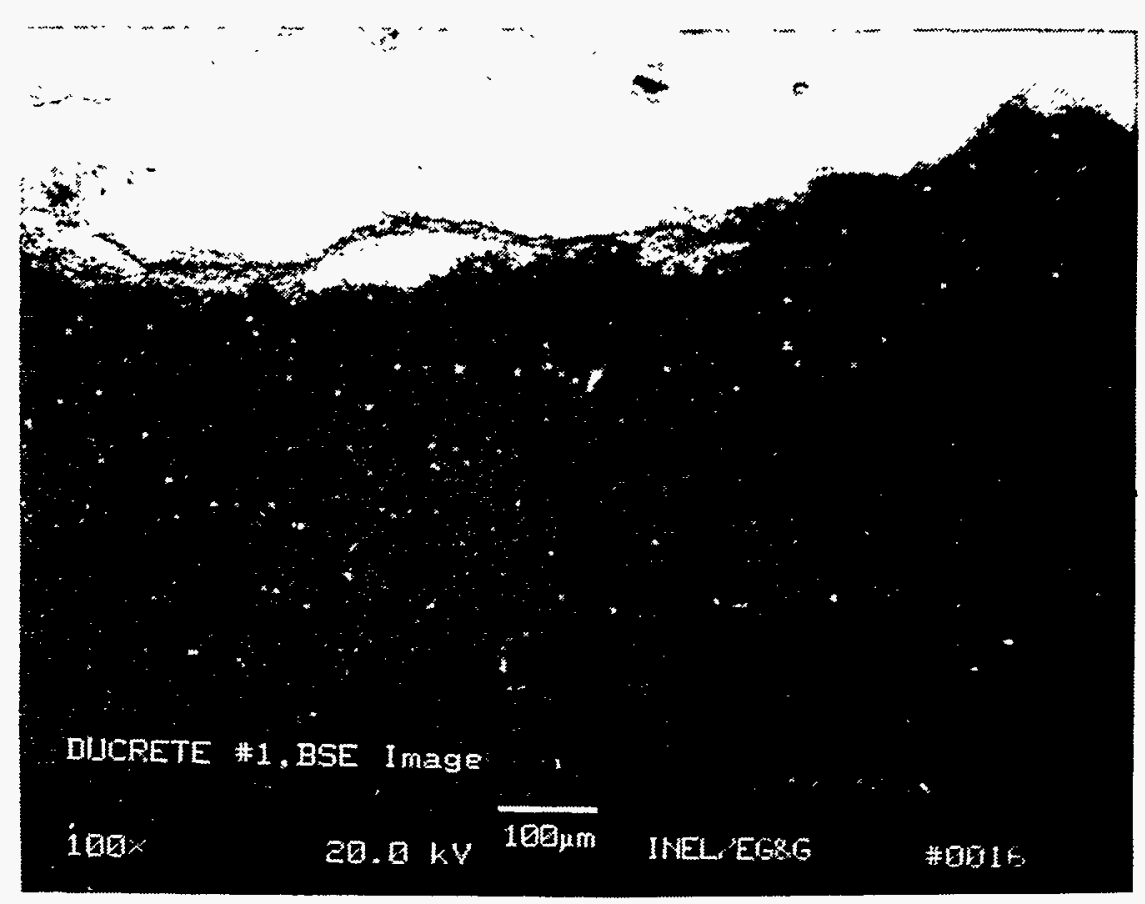

Figure B-19. Sample $\mathrm{U}_{3} \mathrm{O}_{8}-01$ ( $250^{\circ} \mathrm{C}$ for 14 days) - SEM micrograph (backscatter mode).

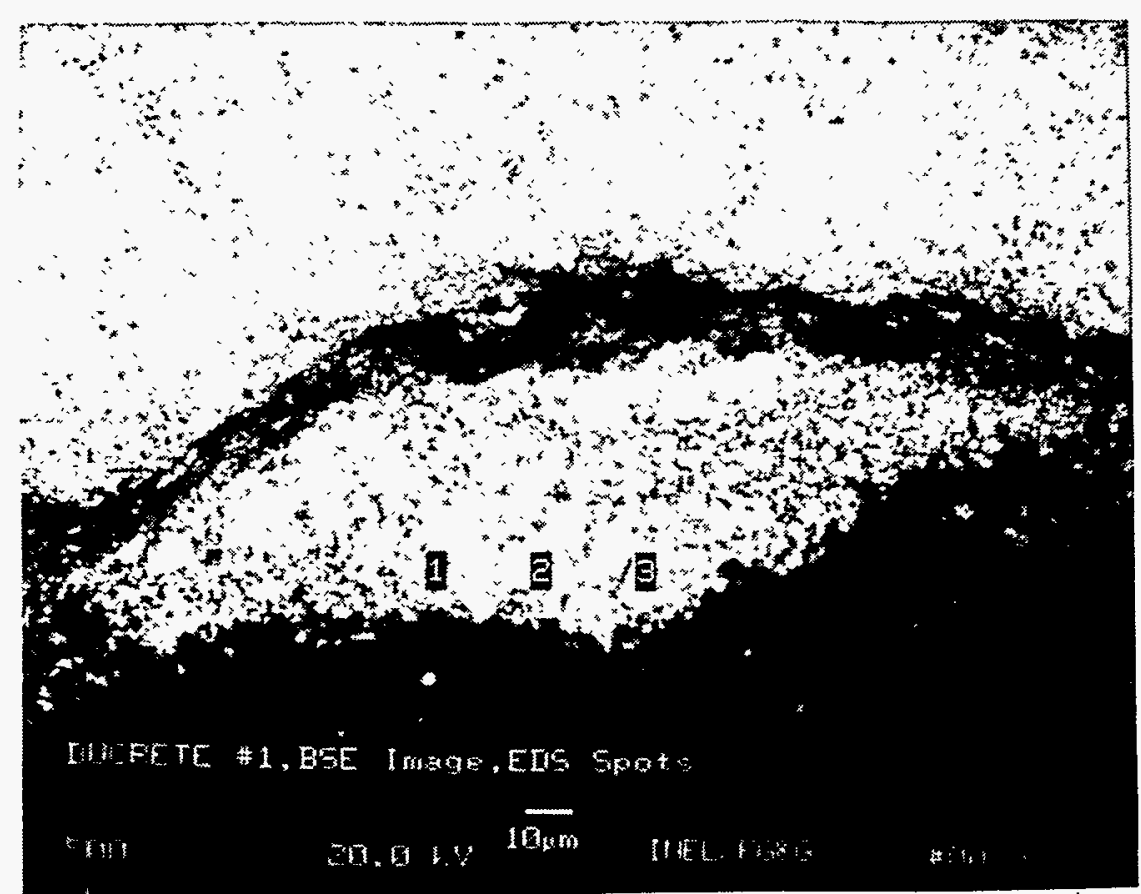

Figure B-20. Sample $\mathrm{U}_{3} \mathrm{O}_{8}-01\left(250^{\circ} \mathrm{C}\right.$ for 14 days) - SEM micrograph (backscatter mode) showing area at edge where EDS analysis was performed. 


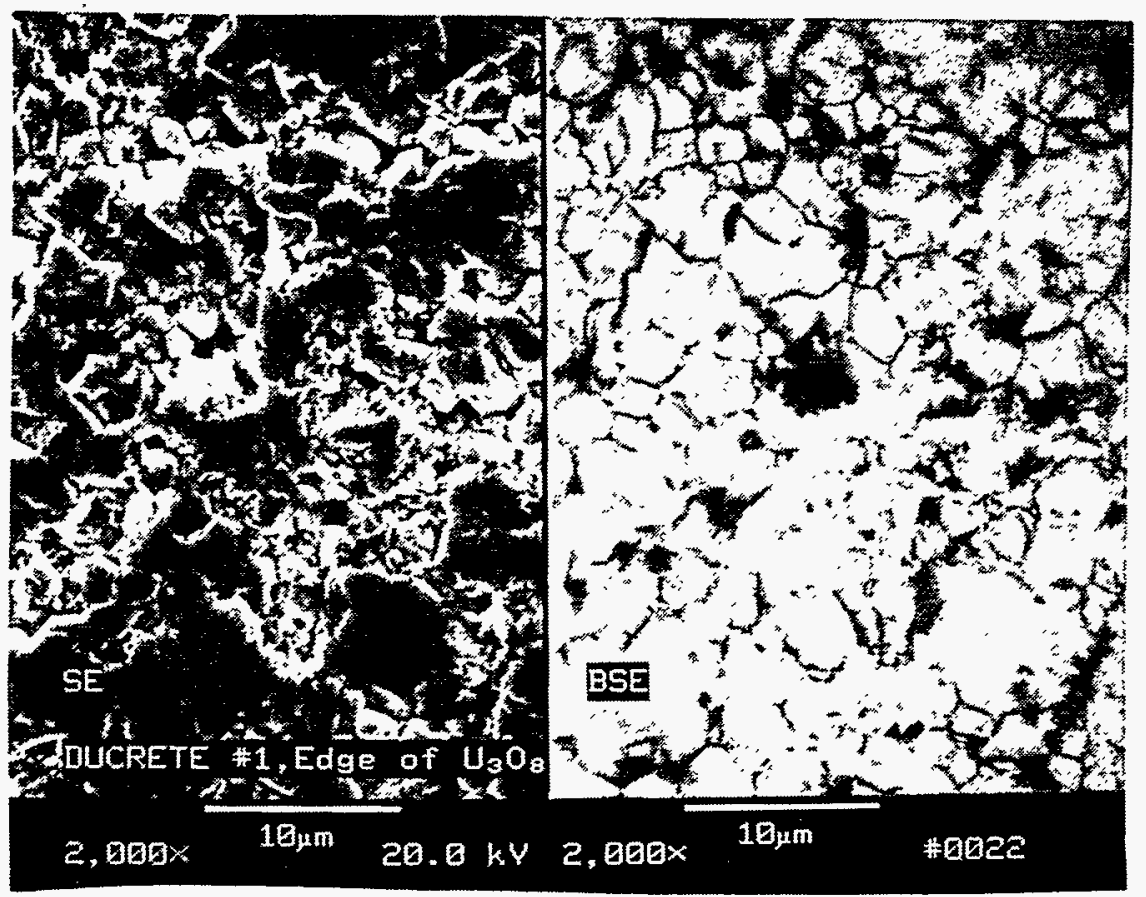

Figure B-21. Sample $\mathrm{U}_{3} \mathrm{O}_{8}-01\left(250^{\circ} \mathrm{C}\right.$ for 14 days) - SEM micrograph showing both normal and backscatter mode of fractures occuring in edge area.



Figure B-22. Sample $\mathrm{U}_{3} \mathrm{O}_{8}-01\left(250^{\circ} \mathrm{C}\right.$ for 14 days) - SEM micrograph (backscatter mode) showing area in center where EDS analysis was performed. 


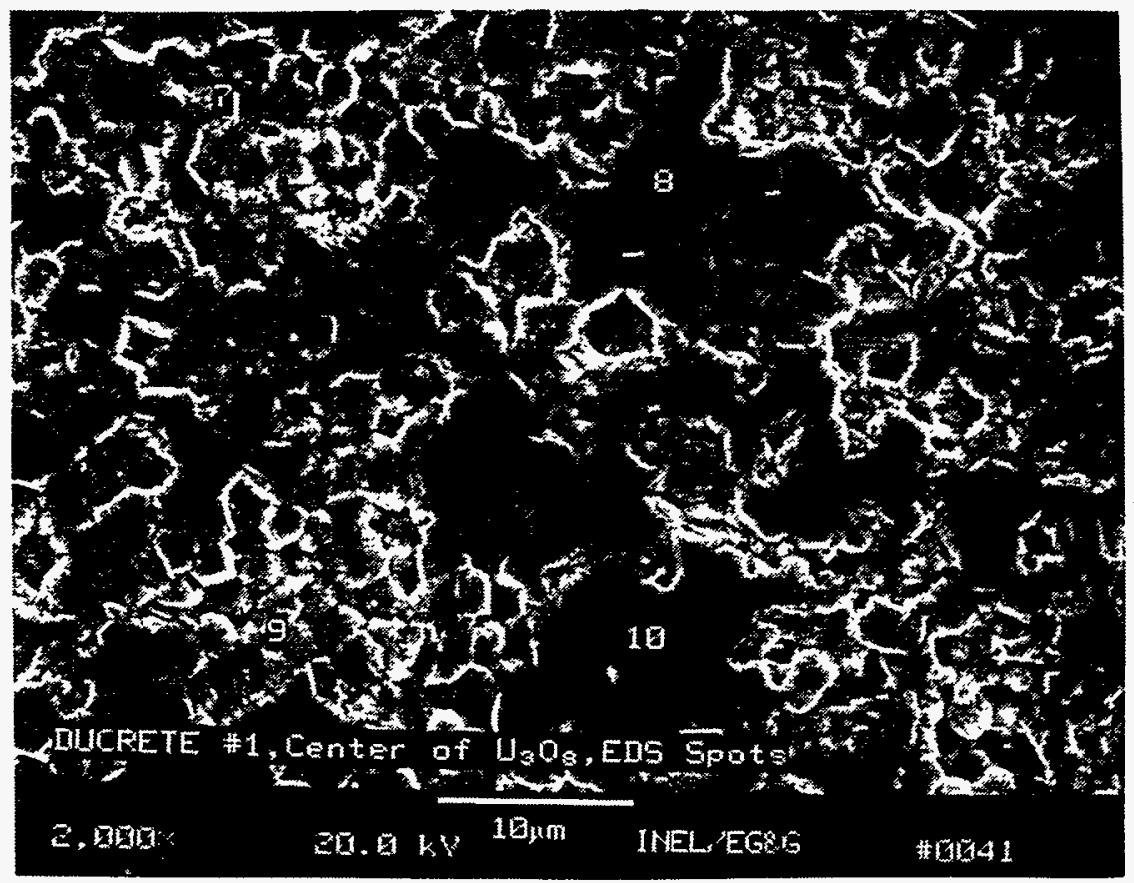

Figure B-23. Sample $\mathrm{U}_{3} \mathrm{O}_{8}-01\left(250^{\circ} \mathrm{C}\right.$ for 14 days) - SEM micrograph showing large and small grains found everywhere in $\mathrm{U}_{3} \mathrm{O}_{8}$. 


\section{Appendix C}

Liquid Phase Sintering of $\mathrm{CeO}_{2}$ Surrogate Using Iron Enriched Basalt (IEB) 



\section{Appendix C}

\section{Liquid Phase Sintering of $\mathrm{CeO}_{2}$ Surrogate Using Iron Enriched Basalt (IEB) \\ SUMMARY}

We have performed liquid phase sintering experiments of $\mathrm{CeO}_{2}$ powder using iron-enriched basalt (IEB) as the liquid phase. Ceria $\left(\mathrm{CeO}_{2}\right)$ has been used as a surrogate for urania in order to quickly gain experimental data on optimum sintering conditions and also to measure some mechanical properties. This appendix gives results that characterize the sintered samples with regard to density, hardness, and fracture toughness.

\section{EXPERIMENTAL}

Controlled sintering experiments were performed using a Taguchi type matrix. Eight combinations of variables were used as shown in Table C-1. The $\mathrm{CeO}_{2}$ used was $99.9 \%$ pure, -325 mesh and mean particle size of $1.5 \mu \mathrm{m}$ (Cerac Stock \# C-1064, Lot \# X13019). Melt \#5 IEB (high in $\mathrm{TiO}_{2}$ and $\mathrm{ZrO}_{2}$ ) was used.

Table C.1. Matrix of experimental variables.

\begin{tabular}{|c|c|c|c|c|c|c|c|}
\hline Sample \# & $\begin{array}{c}\text { IEB } \\
\text { screen } \\
\text { fraction } \\
(\mu \mathrm{m})\end{array}$ & $\begin{array}{l}\text { Firing } \\
\text { atmo- } \\
\text { sphere }\end{array}$ & $\begin{array}{c}\text { Sintering } \\
\text { temperature } \\
\left({ }^{\circ} \mathrm{C}\right)\end{array}$ & $\begin{array}{c}\text { Time at } \\
\text { maximum } \\
\text { temperature } \\
\text { (min.) }\end{array}$ & $\begin{array}{l}\text { Green } \\
\text { forming force } \\
\text { (lb) }\end{array}$ & $\begin{array}{l}\mathrm{Vol} \% \\
\mathrm{CeO}_{2} \text { in } \\
\text { the mix }\end{array}$ & $\begin{array}{c}\text { Powder } \\
\text { calcine at } \\
1000^{\circ} \mathrm{C} ?\end{array}$ \\
\hline 1 & -45 & $\begin{array}{l}\mathrm{Ar} / 4 \% \\
\mathrm{H}_{2}\end{array}$ & 1,300 & 30 & 5,000 & 79.1 & Yes \\
\hline 2 & -38 & $\begin{array}{l}\mathrm{Ar} / 4 \% \\
\mathrm{H}_{2}\end{array}$ & 1,300 & 60 & 10,000 & 79.1 & No \\
\hline 3 & -45 & Ar & 1,300 & 60 & 5,000 & 93.15 & No \\
\hline 4 & -38 & $\mathrm{Ar}$ & 1,300 & 30 & 10,000 & 93.15 & Yes \\
\hline 5 & -45 & $\begin{array}{l}\mathrm{Ar} / 4 \% \\
\mathrm{H}_{2}\end{array}$ & 1,250 & 30 & 10,000 & 93.15 & No \\
\hline 6 & -38 & $\begin{array}{l}\mathrm{Ar} / 4 \% \\
\mathrm{H}_{2}\end{array}$ & 1,250 & 60 & 5,000 & 93.15 & Yes \\
\hline 7 & -45 & $\mathrm{Ar}$ & 1,250 & 60 & 10,000 & 79.1 & No \\
\hline 8 & -38 & Ar & 1,250 & 30 & 5,000 & 79.1 & No \\
\hline
\end{tabular}


The as-pressed samples were disks about 1 in. in diameter by 0.125 in. thick. After sintering, the samples' densities were measured using immersion techniques. Representative samples were cast in plastic metallographic mounts, ground, and polished. These samples were indented using a diamond pyramid microhardness instrument utilizing a 1,000-g load. Multiple indentations were made in every sample. Values from indents made in a porous area were not tabulated. From these indentations (and associated cracks), microhardness and fracture toughness values were calculated.

\section{RESULTS}

Table C-2 gives the bulk densities that were measured for the eight sintered samples.

Table C-2. Sintered (bulk) densities of sintered samples.

\begin{tabular}{crrrrrrrrr}
\hline Sample \# & 1 & 2 & 3 & 4 & 5 & 6 & 7 & 8 - \\
\hline $\begin{array}{c}\text { Bulk } \\
\text { density } \\
\left(\mathrm{g} / \mathrm{cm}^{3}\right)\end{array}$ & 5.67 & 4.94 & 5.92 & 6.42 & 6.41 & 6.41 & 5.83 & 5.63 \\
\hline
\end{tabular}

Table C-3 shows the Taguchi variables and their relative influence on the sintered bulk density. The strongest factor (3.08) indicates that we should have a high loading of $\mathrm{CeO}_{2}$ powder in the mixture. This would be expected if all the bodies are sintering to a relatively high percent of theoretical density and the $\mathrm{CeO}_{2}$ has a higher density than the IEB. The next strongest factor (1.43) shows we should calcine precursor powders in order to drive of adsorbed gases and decompose any carbonates prior to sintering. Similarly, a lower sintering temperature (1.31) and shorter sintering time (1.03) are favored in order to limit decompositions of the IEB phases at high temperatures, which lead to gas bubbles within the body.

The particle size of the IEB showed only a minor effect, probably because there wasn't much difference in the two conditions. The gas atmosphere and pressing load (no binder added) showed little effect on the $\mathrm{IEB} / \mathrm{CeO}_{2}$ combination. This indicates that a reducing atmosphere does not harm the IEB as long as the temperature is kept relatively low. The gas atmosphere will likely have a large effect on sintering of $\mathrm{IEB} / \mathrm{UO}_{x}$ compositions because the uranium oxide is very susceptible to oxidation/reduction, which changes the crystal density. We expect higher sintered densities for IEB/UO ${ }_{x}$ samples when using a reducing atmosphere.

The hardness and toughness values are given in Table C-4. 
Table C-3. Sintered (bulk) density as a function of fabrication variables.

\begin{tabular}{lllllc}
\hline \multicolumn{1}{c}{ Variable } & $\begin{array}{l}\text { Units for } \\
\text { variable }\end{array}$ & $\begin{array}{c}\text { Plus } \\
\text { condition }\end{array}$ & $\begin{array}{c}\text { Minus } \\
\text { condition }\end{array}$ & $\begin{array}{c}\text { Tendency for } \\
\text { density increase if: }\end{array}$ & $\begin{array}{c}\text { Strength of } \\
\text { tendency }\end{array}$ \\
\hline Particle size & micron & -38 & -45 & Larger particle size & -0.43 \\
Atmosphere & Gas & $\mathrm{Ar}$ & $\mathrm{Ar} / 4 \% \mathrm{H}_{2}$ & $\mathrm{Ar}$ & 0.37 \\
$\begin{array}{l}\text { Temperature } \\
\begin{array}{l}\text { Time at } \\
\text { sintering }\end{array}\end{array}$ & min. & 1,250 & 1,300 & Lower temperature & 1.31 \\
temperature & 30 & 60 & Shorter time & 1.03 \\
$\begin{array}{l}\text { Pressing } \\
\text { load }\end{array}$ & $\mathrm{lb}$ & 5,000 & 10,000 & Lower load & \\
$\begin{array}{l}\text { Vol\% CeO }{ }_{2} \\
\text { in the } \\
\text { mixture }\end{array}$ & $\%$ & 79.1 & 93.15 & Higher \% of $\mathrm{CeO}_{2}$ & -3.08 \\
$\begin{array}{l}\text { Powder } \\
\text { calcined }\end{array}$ & Calcined & No & Yes & Calcine powders & -1.43 \\
\hline
\end{tabular}


Table C-4. Measured micro-hardness and toughness values for sintered $\mathrm{CeO}_{2}$ /basalt samples.

\begin{tabular}{|c|c|c|}
\hline Sample \# & $\begin{array}{l}\text { Diamond pyramid hardness number } \\
\qquad(1,000 \mathrm{gm} \text { load })\end{array}$ & $\begin{array}{l}\text { Diamond indentation fracture toughness } \\
\qquad\left(\mathrm{Mpa}^{*} \mathrm{~m}^{1 / 2}\right)\end{array}$ \\
\hline \multirow[t]{4}{*}{1} & 810 & 1.214 \\
\hline & . 810 & 0.666 \\
\hline & 781 & 0.912 \\
\hline & 800 & 1.184 \\
\hline \multirow[t]{3}{*}{2} & 795 & 0.836 \\
\hline & 795 & 0.781 \\
\hline & 810 & 0.886 \\
\hline \multirow[t]{4}{*}{3} & 810 & 0.712 \\
\hline & 781 & 0.779 \\
\hline & 810 & 0.682 \\
\hline & & 0.872 \\
\hline \multirow[t]{5}{*}{4} & 810 & 0.712 \\
\hline & 795 & 0.833 \\
\hline & 795 & 0.920 \\
\hline & & 0.879 \\
\hline & & 0.941 \\
\hline \multirow[t]{4}{*}{5} & 810 & 0.992 \\
\hline & 810 & 0.867 \\
\hline & 825 & 0.937 \\
\hline & . & 0.844 \\
\hline \multirow[t]{5}{*}{6} & 810 & 0.873 \\
\hline & 810 & 0.957 \\
\hline & 795 & 0.996 \\
\hline & & 0.993 \\
\hline & & 0.709 \\
\hline \multirow[t]{3}{*}{7} & 795 & 0.901 \\
\hline & 795 & 0.874 \\
\hline & 825 & 0.828 \\
\hline$\cdot$ & & 0.873 \\
\hline \multirow[t]{4}{*}{8} & 810 & 0.857 \\
\hline & 795 & 1.062 \\
\hline & 810 & 0.764 \\
\hline & & 0.876 \\
\hline
\end{tabular}




\section{DISCUSSION OF RESULTS}

The theoretical density of $\mathrm{CeO}_{2}$ is $7.125 \mathrm{~g} / \mathrm{cm}^{3}$ and the density of IEB is approximately $3.0 \mathrm{~g} / \mathrm{cm}^{3}$. Our highest densities (about $6.41 \mathrm{~g} / \mathrm{cm}^{3}$ ) were achieved with samples $\# 4$, \#5, and \#6, which were $93.15 \mathrm{vol} \% \mathrm{CeO}_{2}$. The theoretical density for this mixture is about $6.843 \mathrm{~g} / \mathrm{cm}^{3}$. Therefore, we achieved $93.7 \%$ of theoretical density. Typical good sintered densities of industrial ceramics are $93-97 \%$ of theoretical density.

The average diamond pyramid hardness number is 805 . Conversion tables indicate that this hardness roughly corresponds to a Rockwell " $\mathrm{C}$ " hardness number of 64 , and a Shore hardness number of 88 . An old text on indentation hardness testing ${ }^{1}$ has a conversion chart that indicates that a Rockwell "C" hardness number of 64 corresponds to a Knoop hardness number of 800 . Therefore, the Vickers Diamond Pyramid Hardness Number is equal to the Knoop Diamond Indentation Number in this hardness range. Therefore, the 805 number can be compared to literature values for the hardness of minerals that were measured using either the Diamond Pyramid or Knoop Diamond tests.

Hardness numbers for natural minerals and man-made ceramics were abstracted from two sources, 3 and are tabulated in Table C-5.

The sintered $\mathrm{CeO}_{2} / \mathrm{IEB}$ average hardness number (805) is much harder than calcite or ordinary window glass, and somewhat higher than quartz. Calcite and quartz type minerals are often used as the aggregate in concrete. It is of interest that hardness number (805) is very close to that of a uranium oxide mineral hardness (Uraninite $=810$ ).

The fracture toughness numbers are plotted in Figure C-1.

There is a lot of scatter to the toughness numbers, with no apparent correlation to the sample number (preparation conditions). The average fracture toughness number is $0.880 \mathrm{MPa} \cdot \mathrm{m}^{1 / 2}$. This number is slightly higher than that of ordinary glass $\left(0.7 \mathrm{Mpa} \cdot \mathrm{m}^{1 / 2}\right)$, while considerably lower than sintered alumina $\left(3.5 \mathrm{MPa} \cdot \mathrm{m}^{1 / 2}\right)$.

\section{CONCLUSIONS}

Using liquid phase (IEB) to sinter fine $\mathrm{CeO}_{2}$ powder, we have achieved $93.7 \%$ of theoretical density. The best densities are achieved with lower sintering temperatures, short sintering times, high $\mathrm{CeO}_{2}$ loadings, and when precursor powders were calcined. Barring unforseen complications (such as bubbling due to decompositions), it is reasonable to assume that we will be able to achieve this level of densities using uranium oxide powder. Since $\mathrm{CeO}_{2}$ has about the same hardness as uranium oxide and the hardness seems to correlate well with the hardness of the major phase, we would predict the hardness value for IEB sintered uranium oxide would have a diamond pyramid hardness number of about 800 . The fracture toughness values seem to be dependent upon the grain boundary (IEB glass/ceramic) phase. Therefore, we predict that IEB sintered uranium oxide would have a similar fracture toughness value (about $0.8-0.8 \mathrm{MPa}{ }^{*} \mathrm{~m}^{1 / 2}$ ). 
Table C-5. Diamond indentation micro-hardness of various materials.

Mineral or Ceramic Name

Gypsum

Calcite

Fluorite

Chalcopyrite

Millerite

Coffinite

Manganite

Soda Lime Glass

Magnetite

Pitchblende

Crystalline Quartz

Uraninite

Rutile

Topaz

Alumina

$\mathrm{SiC}$

$\mathrm{B}_{4} \mathrm{C}$

Diamond
Diamond Indentation Hardness Number

32

135

163

194

236

258

410

538

560

720

750

810

1,139

1,250

1,675

2,100

2,250

6,200

\section{CeO2-basalt}

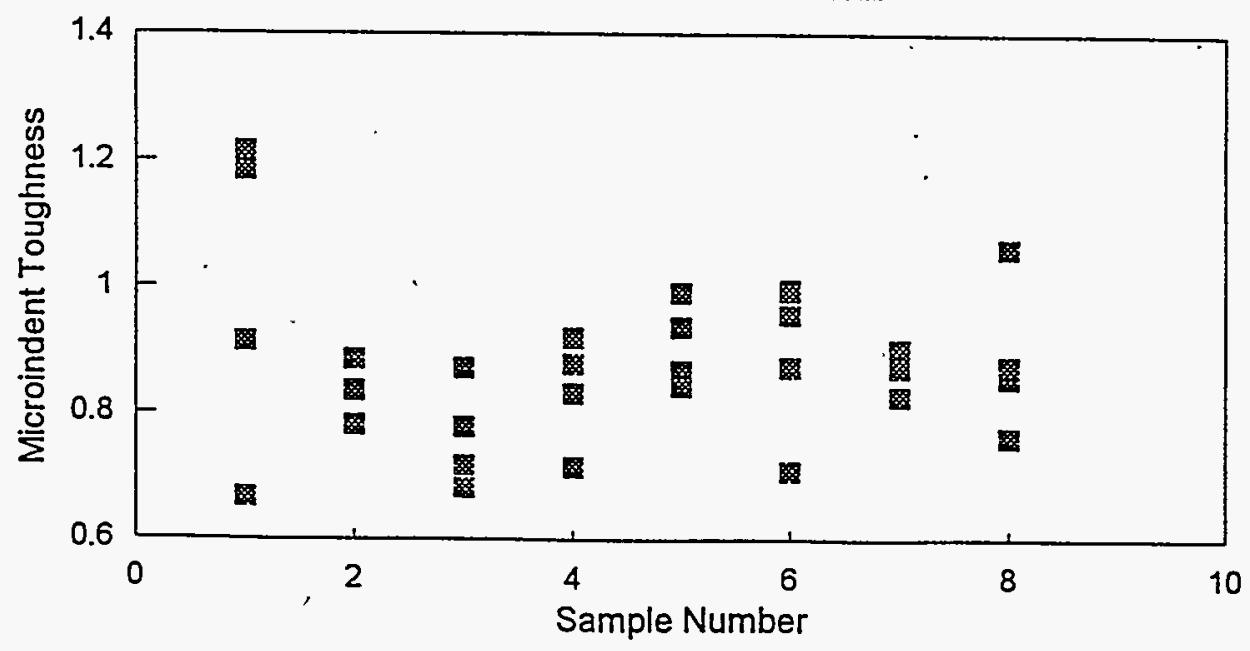

ata A

Figure C-1. Diamond indentation fracture toughness values for sintered $\mathrm{CeO}_{2} / \mathrm{IEB}$. 


\section{REFERENCES}

1. Indentation Hardiness Testing, Vincent E. Lysaght, Reinhold Publishing Corp., 330 West 42 St., New York, 1949.

2. Ibid.

3. Handbook of Physical Properties of Rocks, Robert S. Carmichael, Editor, CRC Press, 1982. 